\title{
SELEÇÃO DE POPULAÇÕES DE CEBOLA (Allium copa L.) DO GRUPO BAIA PERIFORME PARA ÉPOCAS DE CULTIVO NO VALE DO SUBMÉDIO SÃO FRANCISCO
}

\author{
DIMAS MENEZES \\ Engenheiro Agrônomo \\ Empresa Pernambucana de Pesquisa Agropecuária - IPA
}

Orientador: PROF. DR. CYRO PAULINO DA COSTA

Dissertação apresentada à Escola Superior de Agricultura "Luiz de Queiroz", da Universidade de São Paulo, para obtenção do título de Mestre em Genética e Melhoramento de Plantas.

PIRACI CABA

ESTADO DE SÃO PAULO - BRASIL

Março - 1980 
A memória do meu saudoso pai,

SILVIO MENEZES

à minha mãe, irmãos e

Ao primo FLORINHO 


\section{BIOGRAFIA DO AUTOR}

DIMAS MENEZES, filho de Silvio Menezes e Alice Gomes Menezes, nasceu em 29 de abril de 1952, em Floresta, Pernambuco. Em 1969 ingressou no Colēgio Agrícola de São Lourenço da Mata, pertencente à Universidade Federal Rural de Pernambuco, obtendo o diploma de Téç nico Agrícola em dezembro de 1971. Em 1972 ingressou no Curso de Engenharia Agronômi ca da Universidade Federal Rural de Pernambuco, onde por dois anos foi estagiärio do Setor de Olericultura, vindo a se diplo mar em janeiro de 1976. Em fevereiro desse mesmo ano ingressou no Instituto de Pesquisas Agronômicas IPA, hoje Empresa Pernambucana de Pesquisa Agropecuāria - IPA, para colaborar nos trabalhos de melhoramen to de hortaliças, em andamento no Submédio São Fran cisco. 


\section{AGRADECIMENTOS}

- Ao Professor Dr. CYRO PAULINO DA COSTA pela valiosa orientação, estímulo, amizade e principalmente pelos ensinamentos que muito contribuíram para nossa formação profissional;

- Aos Engenhei ros Agrônomos LUIZ JORGE DA GAMA WANDERLEY e PAULO CÉSAR TA. VARES DE MELO pelo apoio e incentivo constante durante o decorrer do curso;

- Aos Engenheiros Agrônomos JONAS ARAOJJO CANDEIA, DIOGENES FERNANDES DA SILVA e EDINARDO FERRAZ pela valiosa colaboração na obtenção dos dados experimentais no Campo Experimental de Jatinã, Belém do São Francisco, Pernambuco;

- Aos colegas HIROSHI NODA e SANDRA DO NASCIMENTO NODA pelas contribuições valiosas e revisão do texto;

- Aos colegas JOÃO RODRIGUES DE PAIVA e WALDELICE DE OLIVEIRA PAIVA pelas valiosas sugestões;

- Ao Professor ANTONIO DURÃES MAIA pela minha iniciação em Olericultura, quando estagiärio na Universidade Federal Rural de Pernambuco;

- Aos DOCENIES DO DEPARTAMENTO E INSTITUTO DE GENETICA DA ESCOLA SUPERIOR DE AGRICULTURA "LUIZ DE QUEIROZ", pelos ensinamentos ministrados;

- Aos funcionārios do DEPARTAMENTO E INSTITUTO DE GENETICA DA ESCOLA SUPERIOR DE AGRICULTURA "LUIZ DE QUEIROZ", especialmente à Srta. ERICA SPRUCK e Sr. ANTONIO CELLA, pela maneira atenciosa como sempre nos atendeu. 
- Aos funcionārios das BIBLIOTECAS CENTRAL E DO INSTITUTO DE GENETICA DA ESCOLA SUPERIOR DE AGRICULTURA "LUIZ DE QUEIROZ", especialmente à Sra. EISA APARECIDA AZEREDO CESAR, Sra. TEREZINHA DE JESUS LODOVICO. e Sr. LUIZ CARLOS VERISSIMO, pela solicitude no atendimento;

- Aos funcionārios da SEÇ̃̃O DE PŐS-GRADUACÃO DA ESCOLA SUPERIOR DE AGRICULTURA "LUIZ DE QUEIROZ", especialmente à Sra. DIRCE ALESSI PELEGRINO e Srta. LUZIA ARANA, pela maneira atenciosa como sempre nos acolheu;

- A EMPRESA PERNAMBUCANA DE PESQUISA AGROPECUARIA - IPA, pe la oportunidade concedida para a realização do curso de Mestrado;

- A EMPRESA BRASILEIRA DE PESQUISA AGROPECUARIA - EMBRAPA, pela bolsa de estudo oferecida;

- ASUDENE e BRASCAN-NE, que financiaram o PROJETO MELHORAMENTO GENETICO E PRODUCAOO DE SEMENTES DE CEBOLA PARA O NORDESTE, realizado pela EMPRESA PERNAMBUCANA DE PESQUISA AGROPECUARIA - IPA, com a assessoria do INSTITUTO DE GENETICA DA ESCOLA SUPERIOR DE AGRICULTURA "LUIZ DE QUEIROZ", tornando possivel a realização deste trabalho;

- Aos COLEGAS dO CURSO DE POS-GRADUAÇÃO EM. GENETICA E MELHORAMENTO DE PLANTAS e aos AMIGOS pelo companheirismo e pelos momentos alegres;

- E A TODOS QUE DIRETA OU INDIRETAMENTE COLABORARAM PARA A REALIZACÃO DESTE TRABALHO. 


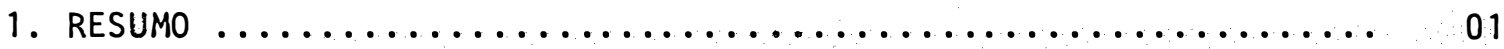

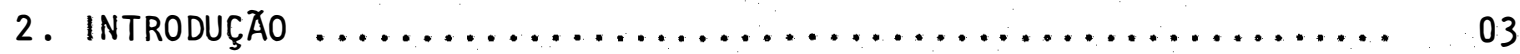

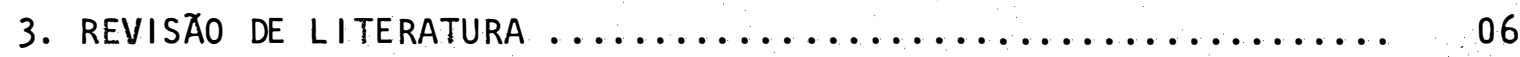

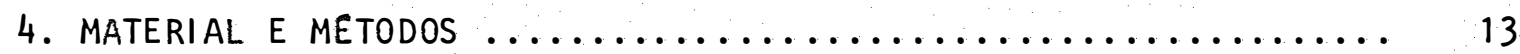

4.1. Origem e Características das Populações de Cebola utiliza

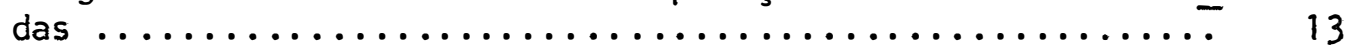

4.2. Obtenção das Populações Selecionadas ................ 15

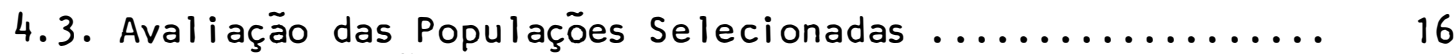

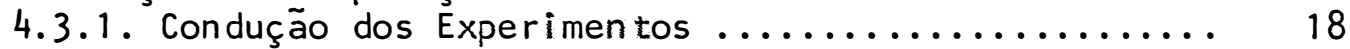

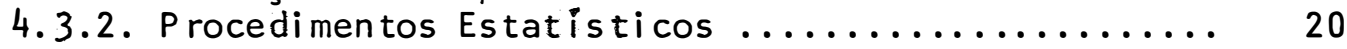

4.3.3. Obtenção dos Dados Experimentais .............. 22

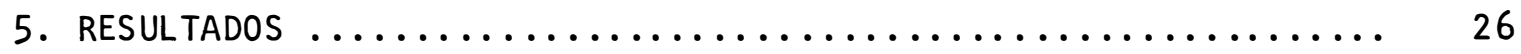

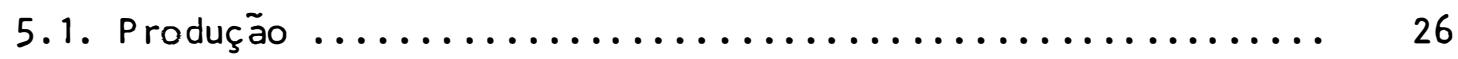

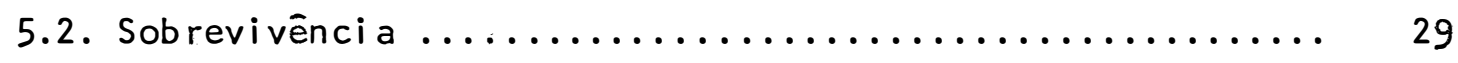

5.3. Bulbos Comerciais ........................ 32

5.3.1. Bulbos Comerciais de Peso Inferior a $50 \mathrm{~g} . \ldots \ldots . .35$

5.3.2. Bulbos Comerciais de Peso entre 50 e $150 \mathrm{~g} \mathrm{.......} 38$

5.3.3. Bulbos Comerciais de Peso Superior a $150 \mathrm{~g} . . . . .4 \quad 40$

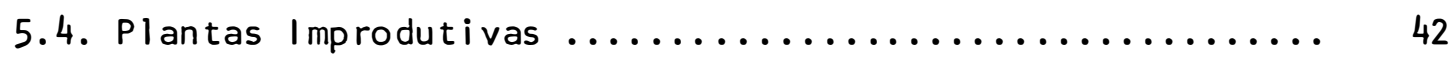

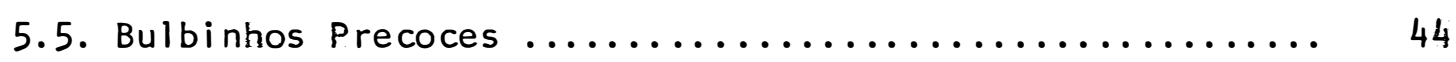

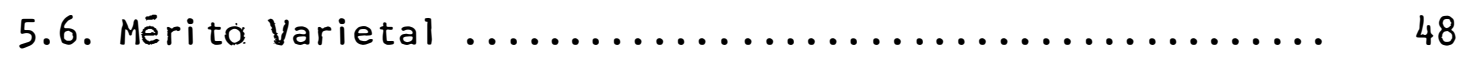

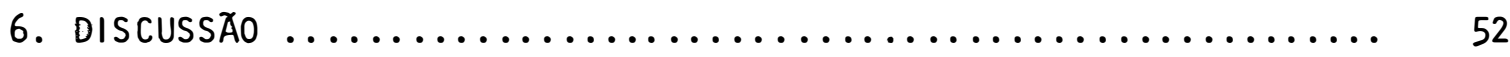

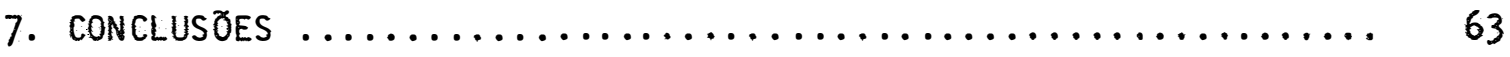

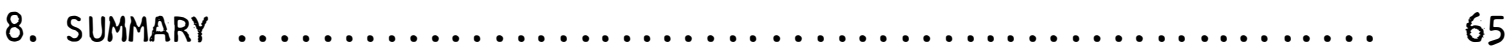

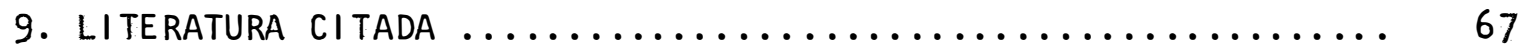

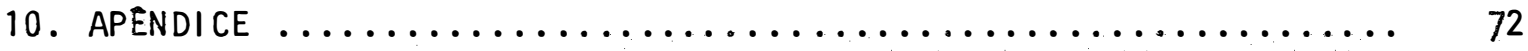

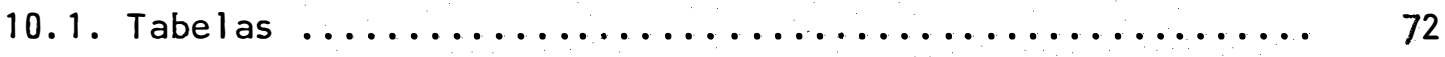

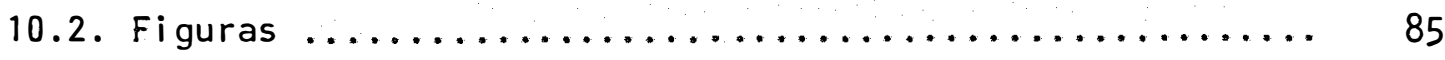




\section{LISTA DE TABELAS}

Tabela

Página

01 - Valores e significâncias dos quadrados médios para o mérito varietal e cinco caracteres de cebola avaliados no cultivo de verão. Experimento 1. Belēm do São Francisco, PE., $1977 / 78 \ldots \ldots \ldots \ldots \ldots \ldots \ldots \ldots \ldots \ldots \ldots \ldots$

02 - Valores e significâncias dos quadrados mëdios para o mérito varietal e cinco caracteres de cebola avaliados no cultivo de fevereiro-julho. Experimento 11 . Belém do

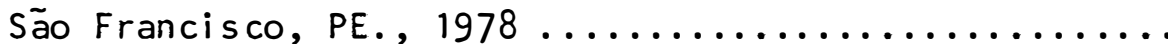

03 - Valores e significâncias dos quadrados médios para o mérito varietal e cinco caracteres de cebola avaliados no cultivo de inverno. Experimento 111 . Belēm do São

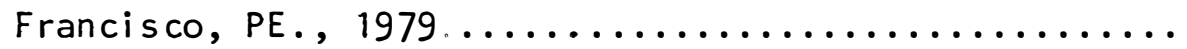

04 - Valores médios do mérito varietal, produção, sobrevivência, bulbos comerciais, plantas improdutivas e bulbinhos precoces. Cultivo de verão. Experimento 1. Belēm

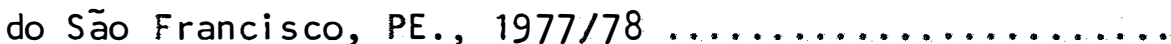

05 - Valores médios do mérito varietal, produção, sobrevivência, bulbos comerciais, plantas improdutivas e bulbinhos precoces. Cultivo de fevereiro-julho. Experimento 11 . Belēm do São Francisco, PE., $1978 \ldots \ldots \ldots \ldots \ldots \ldots \ldots \ldots$ 
06 - Valores mëdios do mërito varietal, produção, sobrevivência, bulbos comerciais, plantas improdutivas e bulbinhos precoces. Cultivo de inverno. Experimento 111 . Be-

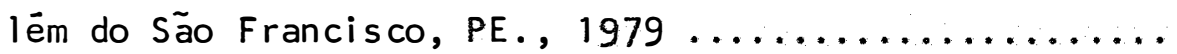

07 - Valores e significâncias dos quadrados médios para o carăter bulbos comerciais classificados em três categorias de peso. Cultivo de verão. Experimento 1. Belēm do

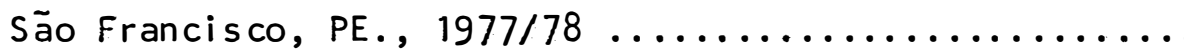

08 - Valores e significâncias dos quadrados médios para o carăter bulbos comerciais classificados em três categorias de peso. Cultivo de fevereiro-julho. Experimento 11 .

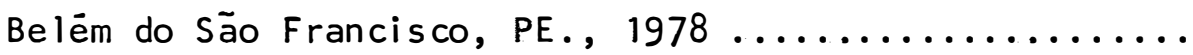

09 - Valores e significâncias dos quadrados médios para o carăter bulbos comerciais classificados em três categorias de peso. Cultivo de inverno. Experimento 111. Belēm

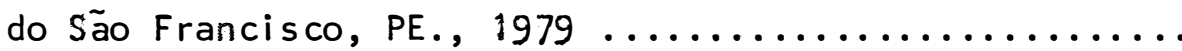

10 - Nümero médio de bulbos comerciais de cebola classificados em três categorias de peso. Cultivo de verão. Experimento 1. Belēm do São Francisco, PE., 1977/78 .... 
-viii-

Tabela

Página

11 - Nümero médio de bulbos comerciais de cebola classificados em três categorias de peso. Cultivo de fevereirojulho. Experimento II. Belēm do Säo Francisco, PE.,

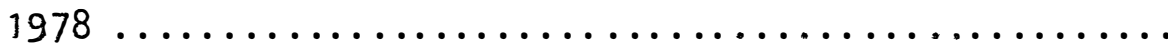

12 - Nümero médio de bulbos comerciais de cebola classificados em três categorias de peso. Cultivo de inverno. Experimento 111. Belēm do São Francisco, PE., 1979 .. 


\section{LISTA DE FIGURAS}

Figura

Pägina

01 - Médias mensais das temperaturas mäximas e mínimas dos anos de 1969 a 1978. Médias mensais das temperaturas mä ximas e mínimas durante a condução dos experimentos. Cam po Experimental de Jatinã, Belēm do São Francisco, PE .. 86

02 - Efeito da seleção massal estratificada $(X)$ na produção (Y). Cultivo de verão. Experimento I. Belém do São

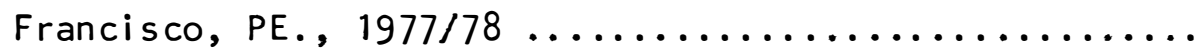

03 - Efeito da seleção massal es tratificada $(X)$ na produção (Y). Cultivo de fevereiro-julho. Experimento 11. Be

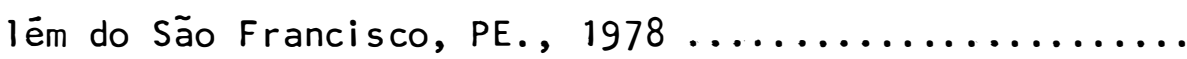

04 - Efeito da seleção massal estratificada (X) na sobrevivên cia pós-transplante $(Y)$. Cultivo de verão. Experimen to 1. Belém do São Francisco, PE., 1977/78 ...........

05 - Efei to da seleção massal estratificada (X) na sobrevivên cia pós-transplante $(Y)$. Cultivo de fevereiro - julho. Experimento 11. Belém do São Francisco, PE., 1978 .....

06 - Efeito da seleção massal estratificada (X) sobre o nümero de bulbos comerciais (Y). Cultivo de verão. Experimento I. Belém do São Francisco, PE., 1977/78 ...... 
07 - Efeito da sel eção massal estratificada (X) sobre o nūme ro de bulbos comerciais $(Y)$. Cultivo de fevereirojulho. Experimento II. Belēm do São Francisco,o, PE.,

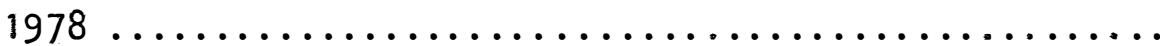

08 - Efeito da seleção massal estratificada (X) sobre o nüme ro de bulbos de peso inferior a $50 \mathrm{~g}(\mathrm{Y})$. Cultivo de verão. Experimento 1. Belém do São Francisco, PE.,

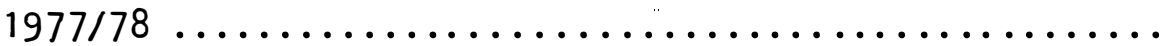

09 - Efeito da seleção massal estratificada (X) sobre o nüme ro de bulbos de peso inferior a $50 \mathrm{~g}(\mathrm{Y})$. Cultivo de fevereiro-julho. Experimento 11. Belēm do São Francisco, PE., 1978

10 - Efeito da seleção massal estratificada (X) sobre o nüme ro de bulbos com peso entre 50 e $150 \mathrm{~g}(\mathrm{Y})$. Cultivo de verão. Experimento 1. Belēm do São Francisco, PE.,

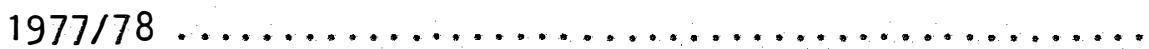

11 - Efeito da seleção massal estratificada (X) sobre o nüme ro de bulbos com peso entre 50 e $150 \mathrm{~g}(\mathrm{Y})$. Cultivo de fevereiro-julho. Experimento II. Belēm do São Francisco, PE., $1978 \ldots \ldots \ldots \ldots \ldots \ldots \ldots \ldots \ldots \ldots \ldots \ldots \ldots$ 
12 - Efeito da seleção massal estratificada (X) sobre o nūmero de plantas improdutivas $(Y)$. Cultivo de verao. Expe rimento 1. Belēm do São Francisco, PE., 1977/78 ......

13 - Efeito da seleção massal estratificada (X) sobre o nüme ro de plantas improdutivas (Y). Cultivo de fevereirojulho. Experimento 11 . Belēm do São Francisco, PE.,

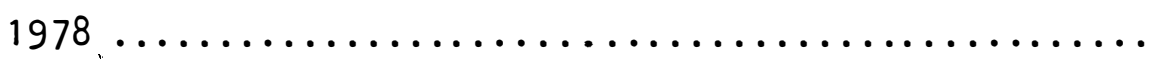

14 - Efeito da seleção massal estratificada (X) sobre o nüme ro de bulbinhos precoces $(Y)$. Cultivo de verão. Experi mento I. Belēm do São Francisco, PE., 1977/78 .......

15 - Efeito da seleção massal estratificada (X) sobre o nüme ro de bulbinhos precoces $(Y)$. Cultivo de fevereirojulho. Experimento II. Belēm do São Francisco, PE., 1978

16 - Efeito da seleção massal estratificada (X) sobre o méri to varietal (Y). Cultivo de verão. Experimento I. Belēm do São Francisco, PE., 1977/78 .............

17 - Efeito da seleção massal estratificada (X) sobre o méri to varietal $(Y)$. Cultivo de fevereiro - julho. Experimento 11. Belēm do São Francisco, PE., 1978 ..... 


\section{RESUMO}

Cultivares de cebola do Grupo Baia Periforme mostraram-se as mais promissoras para o cultivo no Vale do Submédio São Francisco, sitü ado entre $8^{\circ}$ e $9^{\circ}$ de latitude Sul, onde o fotoperíodo é constante em torno de 12 horas. 0 objetivo do presente trabalho foi verificar a eficiéncia da seleção de populações de cebola para épocas específicas de cultivo, bem como efeitos recíprocos da seleção em outras épocas.

O melhoramento de cebola do Grupo Baia Periforme para as condições do Vale do Submédio São Francisco foi baseado na seleção massal estratificada, em duas épocas de cultivo, tendo como critério seletivo bul bos individuais com peso superior a 100 gramas. Populações originais da Baia do Cedo e Composto Baia foram selecionadas no cultivo de fevereirojulho e da Baia Triunfo no cultivo de verão. Procedeu-se de dois a trés ciclos seletivos.

Foram realizados três experimentos no delineamento de blocos casualizados, em três épocas de cultivo, definidas pelo fator tempera- 
tura: cultivo de verão (outubro-março), cultivo de fevereiro-julho e culti vo de inverno (abril-setembro). O progresso obtido pela seleção foi estí mado através do coeficiente de regressão linear e da análise da variáncia. A testemunha foi a cultivar Amarela Chata das Canárias, que apresenta comportamento bem definido na região. Os caracteres avaliados foram produ ção (t/ha), sobrevivéncia, bulbos comerciais, plantas improdutivas e bulbí nhos precoces. Todos os caracteres foram ponderados através de um índice empírico denominado de mérito varietal.

A seleção para condições de temperaturas elevadas, realizada na Baia Triunfo, mostrou ser mais promissora e específica para o cultivo de verão. Contudo, apresentou comportamento inferior no cultivo de in verno, onde verificou-se acentuado aumento do nümero de plantas improdutivas. As populações selecionadas no cultivo de fevereiro-julho apresenta ram ganhos em todas as épocas. Os maiores ganhos foram específicos tanto para o cultivo de fevereiro-jultho como para o de inverno.

A seleção de populações em épocas contrastantes de cultivo viabilizam o cultivo de cebola de maneira escalonada, durante todo o ano, nos trópicos, onde a temperatura mostra-se como fator determinante e primá rio no comportamento varietal de cebolas de dias curtos. 


\section{INTRODUÇÃO}

o Vale do Submédio São Francisco, localizado no Nordeste Brasileiro entre os paralelos $8^{\circ}$ e $9^{\circ}$ de latitude Sul, tem a cultura da ce bola como uma das maiores expressões econômicas e sociais.

A cultura da cebola nesta região tem como principal época de plantio os meses de fevereiro e março, visando o abastecimento do Centro-Sul na entressafra. Atualmente as épocas de plantio têm sido ampliadas, cultivando-se cebola o ano todo. Este fato torna esta região produtora a mais privilegiada entre as outras, prestando-se como uma opção para produção de emergência em decorréncia de perdas nas outras regiões brasileiras.

Na região tropical e semi-árida do Vale do Submédio São Francisco a temperatura deve ser o fator envolvido na adaptação de cultiva res de cebola de dias curtos. Enquanto existe relativa constáncia para fotoperíodo, sendo favorável para essas cultivares, o mesmo não acontece com a temperatura. 
Levando-se em conta o fator temperatura, pode-se dividir o ano agrícola do Submédio São Francisco em três épocas distintas para a pro dução de cebola. A primeira época, denominada cultivo de fevereiro-julho, coincide com a entressafra do Centro-Sul e abrange um período de temperatü ras intermediárias entre as outras duas épocas. A segunda época, denominada cultivo de inverno, abrange o período de abril a setembro, sendo a época mais favorável ao cultivo de cebola na região devido às temperaturas relativamente amenas. A terceira época, cultivo de verão, abrange o perí odo de outubro a março, caracterizado pela ocorréncia de temperaturas elevadas durante todo o período, considerado desfavorável ao cultivo da cebola.

A cebola depende da interação entre fotoperíodo e temperatü ra para adaptar-se a regiões com diferentes latitudes, microclimas, épocas ou sistemas de cultivo, não existindo cultivares versáteis para todas as condições mencionadas. A experiência dos melhoristas tem demonstrado que a melhor cultivar de cebola tem sido conseguida quando a seleção foi feita nas condições específicas, sob as quais se realizarão os cultivos comerciais.

A cultivar Amarela Chata das Canárias, proveniente das Ilhas Canárias, Espanha, adapta-se às condições tropicais do Vale do Submédio São Francisco. Apresenta, entretanto, atributos indesejáveis, tais como susceptibilidade às doenças e alta perecibilidade dos bulbos.

Populações de cebola do Grupo Baia Periforme mostraram-se promissoras na região do Submédio São Francisco, pela melhor conservação 
de bulbos, resistência às principais doenças e com viabilidade de produzir sementes no Brasil. Apresentaram, entretanto, baixa produtividade. A partir de 1972, iniciou-se um programa de melhoramento de populações do Grupo Baia Periforme, inicialmente apenas na época comercialmente mais importante, cultivo de fevereiro-julho, cujos resultados foram relatados por MELO (1978). Posteriormente desenvolveu-se o interesse de selecionar populações de Baia Periforme nas condições de verão, que é a época mais adversa ao cultivo sob o ponto de vista das temperaturas prevalecentes nesta época do ano. A seleção de cultivares de cebola no verão possibilita, an tes de tudo, um esquema anual de produção de sementes, permitindo encurtar o ciclo que no primeiro caso é bienal.

Inicialmente postulou-se que a seleção de bulbos na cultura de verão poderia ser mais eficiente e com melhores resultados que no culti vo de fevereiro-julho, por ser feita sob condições adversas.

O presente trabalho procura responder às seguintes perguntas:

a) A seleção de bulbos de cebola do Grupo Baia Periforme, nas condi ções mais desfavoráveis seria inferior, neutra ou superior à rea lizada no cultivo de fevereiro-julho ?

b) Quais as alterações e progressos em decorréncia da seleção específica para épocas de cultivo, quando as respectivas seleções são testadas de maneira recíproca? 


\section{REVISÃO DE LITERATURA}

A cebola (Allium cepa L.) é uma das mais antigas plantas cultivadas, sendo hoje uma das hortaliças mais populares do mundo. A ori gem da cebola não está perfeitamente estabelecida, supondo VAVILOV (1951), que o seu centro principal deve-se localizar na Asia Central. Até hoje, nunca foi encontrada qualquer forma silvestre de cebola. Dada a sua anti guidade e dispersão nas mais diversas regiões do mundo, a cebola tem sido submetida a uma longa e intensa seleção que possibilitou a origem de elevą do nümero de cultivares. VILMORIN 1/ (1883), descreveu sessenta cultiva res e TRACY 2 I (1901) apresentou uma relação de quatrocentas cultivares comerciais. Atualmente existe número superior de cultivares e híbridos, es pecialmente adaptados para regiões de clima temperado.

Trabalhos de pesquisa e experimentação, de cunho científico, na cultura da cebola obtiveram maior impulso com a descoberta da reação dessa espécie ao fotoperíodo por GARNER e ALLARD ( 1920). Observaram que

1/ e 2/: Citados por GARDE (1977) 
a cultivar Silversking, quando submetida à regime de 10 horas de luz diária, não formava bulbos durante os 12 meses de observação. Cultivando-a em regime de 14 horas de luz diária obtiveram bulbos normais no período de verão em latitudes acima de $40^{\circ}$. Posteriormente, confirmou-se a descoberta de Garner e Allard quanto a exigéncia de fotoperiodismo da cebola pa ra a formação de bulbo. Dentre as pesquisas realizadas com o intuito de deterninar o fotoperíodo crítico, abaix do qual as cultivares não formam bulbos normais, destacam-se os trabalhos de MAGRUDER (1937), nos quais foram incluídas as principais cultivares de cebola utilizadas na América do Norte e os de TORRES (1951), envolvendo cinco cultivares de cebola produzi das na Estação Domingos Petrolini, Rio Grande do Sul, no Brasil. o fotoperíodo é fator ambiental, implicado na formação de bulbos, que depende apenas da latitude, e oscila de acordo com as estações do ano. No verão ocorre a máxima expressão, enquanto no inverno é menor. Na região do equador é constante durante o ano todo em torno de 12 horas diárias.

A temperatura é o segundo fator climático que influencia a formação de bulbos. WALKER e JONES (1921) mostraram que a temperatura do ar e do solo tem efeito pronunciado sobre a velocidade de crescimento em plântulas de cebola. Verificaram que o sistema radicular e a parte aérea exigem temperaturas diferentes para o crescimento ótimo, bem como as culti vares mostraram requerimentos diferenciais quanto à temperatura ótima para - seu desenvolvimento. D maior crescimento do sistema radicular de Red Globe ocorreu em torno de $14^{\circ} \mathrm{C}$, no solo e a $20^{\circ} \mathrm{C}$ para Yellow Bermuda. $\mathrm{O}$ crescimento máximo da parte aérea de Red Globe ocorreu a $20^{\circ} \mathrm{C}$ no solo e pa ra Yellow Bermuda a $25^{\circ} \mathrm{C}$. Numa temperatura do solo de $35^{\circ} \mathrm{C}$, tanto a ger- 
minação como o desenvolvimento foram substancialmente menores. A tempera tura do ar variou de $15,5^{\circ} \mathrm{C}$, mínima noturna, até $29,4^{\circ} \mathrm{C}$ de temperatura máxima, ao meio dia. GARNER e ALLARD (1923), cultivando cebola em casa de vegetação, durante o verão, notaram que as plantas bulbificaram com tamanho menor do que aquelas cultivadas no campo no mesmo período. A explicação para os comportamentos contrastantes foi atribuída às diferenças de temperatura nos dois ambientes. A influência que a temperatura exerce so bre o desenvolvimento vegetátivo e formação de bulbos, ficou patente com os trabalhos de THOMPSON e SMITH (1938), que estudaram trés cultivares, sob duas condições fotoperiódicas, variando apenas as condições de temperatura. Sob condições de dias curtos não formaram bulbos em qualquer dos regimes de temperatura, porém, quando mantidos em dias longos ocorreu bulbificação a partir de $15,5^{\circ} \mathrm{C}$. Mantendo o fotoperiodismo de dias longos, ve rificou-se que entre $10^{\circ} \mathrm{C}$ e $15,5^{\circ} \mathrm{C}$ não formaram bulbos. Na faixa de 15,5 a $21^{\circ} \mathrm{C}$ houve bulbificação, apesar da maturação lenta. Entre $21^{\circ}$ e $26,5^{\circ} \mathrm{C}$ formaram-se ótimos bulbos e o ciclo vegetativo completou-se um més antes do tratamento anterior. A temperatura isoladamente não foi capaz de causar bulbificação sem que as exigèncias fotoperiódicas das cultivares fossem satisfeitas. Assim, a interação do comprimento do dia com a tempera tura determina a bulbificação e, consequentemente, a adaptabilidade de cul tivares de cebola, nas diversas regiões geogräficas e épocas de cultivo. HEATH (1943), estudando os efeitos de comprimento do dia e temperatura, em cebolas cultivadas pela técnica de bulbinho, constatou que a emissão de no vas folhas cessa abruptamente ao iniciar a bulbificação sob condições de temperaturas elevadas. Confirma, também, a existência de interação entre temperatura e fotoperíodo na formação de bulbos de cebola. 
A área foliar influencia o desenvolvimento normal de bulbos de cebola. BAKER e WILCOX (1961), estudando os efeitos da redução da area foliar e população de plantas por área mostraram que a redução da área foliar, no início da bulbificação, causou grande redução na produção e no tamanho do bulbo. Reduzindo a população da plantas, baixou substancialmente a produção por unidade de área.

YAMAGUCHI et alii (1975), estudando o efeito da temperatura do solo sobre as qualidades de bulbos de cebola, encontrou correlação posí tiva entre temperatura e pungência, porém, não encontrou correlação entre temperatura e outros caracteres como porcentagem de peso seco, açücares totais e coloração. Os bulbos amadureceram antecipadamente a $29^{\circ} \mathrm{C}$, no entanto, as maiores produções ocorreram em condições de temperatura entre 18 e $24^{\circ} \mathrm{C}$. 0 comprimento vertical do bulbo aumentou em função do aumento de temperatura do solo, mas o diâmetro não foi significativamente diferente.

Vários pesquisadores admitem que nas regiões de clima temperado, a bulbificação é, primariamente, uma função do comprimento do dia, e que a temperatura tem somente a função de alterar a sua maturação (HEATH, 1945).

Em condições tropicais, onde variações sazonais em fotoperí odo são mínimas e as temperaturas elevadas, há evidências no comportamento de cultivares de cebola, locais e introduzidas, que a temperatura exerce influência considerável na bulbificação. As cultivares reagem diferencialmente sob temperaturas elevadas; bulbificando precocemente ou resultan 
do em plantas improdutivas que permanecem vegetando por todo o ciclo (ABDALLA, 1967; COSTA, 1978; MELO, 1978; WANDERLEY et alii, 1978). Todos concordam na necessidade do melhor conhecimento do comportamento de cultivares de cebola quanto a sua reação às temperaturas elevadas. Apontam, também, a necessidade da obtenção, através de melhoramento genético, de cultivares produtivas, com boa conservação e outras características agronô micas desejäveis, adaptadas às regiões tropicais.

DIAS (1970), referindo-se às cultivares de cebola que pertencem ao grupo de dias curtos, no mundo, afirma que esse grupo é paupérri mo em cultivares amarelos com boa conservação, constituindo exceções a cul tivar brasileira Baia Periforme Precoce e a sul-africana Cape Flat.

Na década de 50, segundo KUCKUCK e KOBABE(1959), houve mai or atuação na obtenção de novas cultivares de cebola por métodos simples de seleção como a massal e através de progênies. 0 enfoque refere-se aos caracteres de produtividade, formato, cor e solidez de bulbos, além de maturação uniforme e resistência às doenças. A seleção massal é eficiente no melhoramento das principais características desejáveis em cultivares de cebola. Segundo FALCONER (1960), quando a seleção é feita antes do florescimento aproveita-se toda a variância genética aditiva. Assim, aliado com maior intensidade seletiva, o método de seleção massal é eficiente,sim ples e capaz de proporcionar ganhos substanciais. No Brasil, a seleção massal tem apresentado ótimos resultados, principalmente no melhoramento de caracteres agronômicos desejáveis e na adaptação de cultivares a sistemas e regiões de cultivo. 
DIAS (1963), selecionando no estágio de produção e conserva ção de bulbinhos, bem como no estágio de produção de bulbos, obteve a partir da Baia Periforme Precoce, após dois ciclos de seleção, uma população mais precoce e adaptada ao cultivo de verão por meio de bulbinhos para as condições de São Paulo. A população obtida foi denominada Baia Periforme Precoce Piracicaba. DIAS et alii (1964), praticaram a seleção massal na cultivar Baia Periforme Precoce Piracicaba, visando eliminar o perfilhamen to de bulbinhos. A seleção mostrou-se altamente eficiente. Com apenas um ciclo de seleção obteve-se um progresso de $41,1 \%$ em relação ao ciclo original. DIAS e COSTA (1967), obtiveram um progresso de $44,7 \%$ através de seleção massal, na eliminação da característica florescimento prematuro na cultivar Barreiro. Após dois ciclos de seleção massal na cultivar Baia Periforme Precoce, visando a sua adaptação à cultura de verão através de mudas, DIAS et alii (1969) obtiveram uma população melhorada denominada Baia do Cedo, caracterizada por não apresentar bulbificação precoce na fase juvenil em fotoperíodo excessivo e produzir bulbos comerciais em condi ções de fotoperíodo e temperaturas decrescentes.

LONNQUIST (1960), visando aumentar a eficienncia da seleção massal na cultura do milho, a qual estava sendo considerada por vários pes quisadores como ineficiente para melhorar caracteres de herança complexa, introduziu algumas modificações na técnica de execução da seleção massal. A técnica consiste em dividir a área de seleção em pequenos lotes ou estra tos, onde a seleção é praticada. A seleção é realizada levando-se em con ta apenas a superioridade das plantas dentro do estrato. Esse procedimen to visa controlar ao máximo a heterogeneidade ambiental, principalmente fertilidade, umidade e doenças do solo. 
D método de seleção massal com as devidas modificações introduzidas na técnica tem sido denominada de "seleção massal estratificada" (ZINSLY, 1968).

MELO (1978), evidencia a eficiéncia da seleção massal estrạ tificada no melhoramento de populações de cebola. Após a realização de dois ciclos de seleção nas cultivares Baia do Cedo e Composto Baia, conseguiu um acréscimo na produção, por ciclo de seleção, de 4,47 e 5,05 t/ha, respectivamente, quando cultivadas na mesma região e época de cultivo para a qual foram selecionadas. Houve resposta correlacionada quando as populações selecionadas foram cultivadas no verão, sendo que o acréscimo de produção por ciclo de seleção foi 2,80 t/ha para a Baia do Cedo e 3,94 t/ ha para o Composto Baia. A produção de Bulbos Comerciais ficou reduzida à metade, quando comparada com o cultivo na época para a qual foram seleci onadas. Estes resultados estão de acordo com JONES e MANN (1963), os quais salientam que cultivares de cebola devem ser selecionados para locais e épocas específicas de cultivo. Sabe-se, porém, que as cultivares apresentam variabilidade quanto a maior ou menor interação com época de cultivo na mesma localidade.

A seleção massal para as condições de cultivo no verão em Piracicaba, latitude $22^{\circ} 42^{\prime} \mathrm{S}$, mostrou eficiéncia e ganhos substanciais por ciclo de seleção, em reduzir a bulbificação precoce na fase juvenil e plan tas improdutivas. Aumentou a sobrevivência pós-plantio e produção. Hou ve resposta correlacionada da seleção para condições da cultura de verão, na cultura de inverno, em aumentar a produção e reduzir a ocorrência de plantas improdutivas (COSTA, 1978). 


\title{
4. MATERIAL E METODOS
}

\subsection{Origem e Caracterīsticas das Populações de Cebola Utilizadas}

\begin{abstract}
No presente trabalho foram utilizadas cultivares de cebola adaptadas ao cultivo em dias curtos. Amarela Chata das Canárias e Texas Early Grano foran utilizadas como testemunhas por apresentarem uma boa adaptação ao cultivo na região do Submédio São Francisco e por abrangerem cerca de 90\% da área cultivada com cebola naquela região. As outras popu lações foram obtidas pelo Setor de Melhoramento de Hortaliças do Instituto de Genética da Escola Superior de Agricultura "Luiz de Queiroz", Piracicaba, SP., e pelo Projeto "Melhoramento e Produção de Sementes de Cebola para o Nordeste", executado pelo Setor de Olericultura da Empresa Pernambuca na de Pesquisa Agropecuária - IPA, no Campo Experimental de Jatinã em Belém do São Francisco, PE.
\end{abstract}

As populações básicas das quais foram obtidas os vários ciclos de seleção massal que foram estudadas neste trabalho foram:

a) Baia do Cedo - Cultivar obtida pelo Setor de Melhoramen- 
to de Hortaliças do Instituto de Genética, em Piracicaba, SP., através de seleção massal na cultivar Baia Periforme Precoce, cujas sementes originais foram fornecidas pelo cebolicultor Lacides Antunes Gonçalves, em Rio Grande, RS. DIAS e COSTA (1970) caracterizaram a Baia do Cedo como adaptada ao cultivo de verão por mudas devido à auséncia de bulbificação preco ce na fase juvenil, quando o fotoperíodo é excessivo nas condições de São Paulo. A bulbificação ocorre sob temperatura e fotoperíodo em decréscimo com colheita até junho.

b) Baia Triunfo - Trata-se de uma população Baia Periforme Precoce obtida pelo Setor de Olericultura da Empresa Pernambucana de Pesquisa Agropecuária - IPA, após dois ciclos de seleção massal estratificada realizada no Campo Experimental de Jatinã em Belém do São Francisco, PE., para o cultivo de fevereiro-julho. As sementes originais foram fornecidas pela Secretaria de Agricultura do Rio Grande do Sul. A denominação Baia Triunfo deve-se ao município de Triunfo, PE., onde foram obtidas as sementes.

c) Compos to Baia - Obtida pelo Setor de Melhoramento de HoI taliças do Instituto de Genética, em Piracicaba, SP., através do esquema de policruzamento, envolvendo nove populações Baia Periforme do Rio Grande do Sul. Caracteriza-se por apresentar uma base genética ampla, maturidade equivalente à Baia Periforme, prestando-se para o cultivo na época normal por mudas para as condições de São Paulo (DIAS e COSTA, 1970). 


\section{2: Obtenção das Populações Selecionadas}

As quatro populações estudadas foram obtidas através da seleção massal estratificada, realizada no Campo Experimental de Jatinã, IPA, em Belém do São Francisco, PE., situado na latitude $08^{\circ} 45^{\prime}$ S., com clima tropical semi-árido. As populações selecionadas receberam a denominação original acrescida da sigla SMJ, que significa Seleção Massal realizada em Jatinã, seguida pelo ciclo de seleção correspondente, em algarismos roma nos.

A população básica Baia do Cedo deu origem a duas populações selecionadas que foram denominadas de Baia do Cedo A e Baia do Cedo B representadas neste trabalho pelas iniciais $\mathrm{BC}_{A} \stackrel{\text { *. }}{\mathrm{BC}} \mathrm{B}_{\mathrm{B}}$. A primeira popula ção foi selecionada a partir de um só lote, no Campo Experimental de Jatinã, em 1972. A Baia do Cedo B foi selecionada de vários lotes plantados em propriedades agrícolas particulares em vārios locais da região do Submédio São Francisco, em 1973. A seleção foi feita sempre no cultivo de fevereiro-julho, visando a adaptação das cultivares a essa época de cul tivo.

A seleção no Camposto Baia teve início em 1972, visando a adaptação ao cultivo de fevereiro-julho. O Composto Baia está representą do algumas vezes neste trabalho pelas iniciais CB.

Na Baia Triunfo, obtida após dois ciclos de seleção massal para o cultivo de fevereiro-julho, foi iniciado o processo de seleção visando a sua adaptação ao cultivo de verão, no período de temperaturas mais elevadas no Submédio São Francisco, que corresponde aos meses de ou- 
tubro a março, no verão de 1975/76. - Neste trabalho usa-se, também, as i niciais BT para representar esta cultivar.

A metodologia utilizada no processo seletivo foi a mesma para todas as populações. Consistiu, basicamente, na divisão do campo em estratos de $3,0 \mathrm{~m}^{2}$ de ärea, contendo 150 plantas por ocasião do transplante. Em cada estrato feram selecionados os dez melhores bulbos, levandose em consideração a maturidade precoce, formato, tamanho e coloração de bulbo, bem como o aspecto fitossanitário geral da planta. 0 número de bulbos selecionados variou de 1000 a 2000 para cada ciclo de seleção.

A produção de sementes, realizada após cada ciclo de seleג..

ção na Baia do Cedo e Composto Baia, foi feita no Setor de Melhoramento de Hortaliças do Instituto de Genética da Escola Superior de Agricultura "Luiz de Queiroz" em Piracicaba, SP., utilizando-se o processo de vernalização artificial, completando-se o ciclo de seleção em dois anos. A produção de sementes da Baia Triunfo obedeceu ao esquema anual, onde logo após a seleção os bulbos foram vernalizados artificialmente e plantados para a obtenção de sementes no município de Triunfo, PE., colhendo-se as sementes em tempo hábil para o plantio de verão.

\subsection{Avaliação das Populações Selecionadas}

As populações selecionadas foram avaliadas, juntamente com as testemunhas, em trés épocas distintas de cultivo para os caracteres de produção, sobrevivência, bulbos comerciais, plantas improdutivas e bulbi- 
nhos precoces. Esses caracteres devidamente ponderados deram origem ao mérito varietal, através do qual avaliou-se integradamente todas as características dos materiais, o que é difícil de ser realizado quando se obser va cada característica isoladamente. Os bulbos comerciais foram classifi cados em três grupos, compreendendo bulbos menores que $50 \mathrm{~g}$, entre 50 e $150 \mathrm{~g}$ e maiores que $150 \mathrm{~g}$.

Os experimentos foram realizados em três épocas distintas de cultivo de cebola, levando-se em conta, principalmente, as condições de temperatura prevalecentes na região (Figura 1).

a) Experimento I - Conduzido na época de verão, novembro a março, quando a temperatura atinge o seu valor máximo, sendo a época mais desfavorável ao cultivo da cebola. Denominou-se cultivo de verão ao plantio de cebola nessa fase do ano.

b) Experimento II - Conduzido no período de fevereiro a julho, que corresponde à época tradicional de plantio, visando a colocação do produto no mercado durante a entressafra sulina para a obtenção de melhores preços. Denominou-se cultivo de fevereiro-julho ao plantio de cebola nes sa época do ano.

c) Experimento III - Realizado de abril a setembro, durante a época mais favorável ao cultivo de cebola no Submédio São Francisco, com relação à ocorréncia de temperaturas amenas na fase inicial do ciclo vegetativo, aumentando gradativamente durante a fase de maturação. Denominouse cultivo de inverno ao plantio de cebola nesse período. 


\title{
4.3.1. Condução dos Experimentos
}

Os experimentos foram conduzidos no Campo Experimental de Jatinã, Belém do São Francisco, PE. As datas de semeadura, transplante, primeira e segunda colheitas encontram-se no quadro abaixo.

\begin{tabular}{ccccc} 
Experimento & Semeadura & Transplante & 1a. Colheita & $2 a$. Colheita \\
\hline I & 18.11 .77 & 26.12 .77 & 02.03 .78 & 12.03 .78 \\
II & 24.02 .78 & 31.03 .78 & 05.07 .78 & 24.07 .78 \\
III & 16.04 .79 & 24.05 .79 & 28.08 .79 & 16.09 .79 \\
\hline
\end{tabular}

Os experimentos I e II tiveram tratamentos comuns, incluindo as seguintes populações:

\author{
Amarela Chata das Canárias \\ Baia do Cedo B SMJ-I \\ Baia do Cedo B SMJ-II \\ Baia do Cedo A SMJ-I \\ Baia do Cedo A SMJ-II \\ Baia do Cedo A SMJ-III \\ Composto Baia SMJ-I \\ Composto Baia SMJ-II \\ Composto Baia SMJ-III \\ Baia Triunfo SMJ-O \\ Baia Triunfo SMJ-I \\ Baia Triunfo SMJ-II
}


A cultivar Amarela Chata das Canárias foi utilizada como testemunha, por ser a população mais adaptada às condições de cultivo do Submédio São Francisco. E cultivada durante todo o ano e responsável por mais de $80 \%$ da produção na região.

No experimento III foram incluídas as seguintes cultivares:

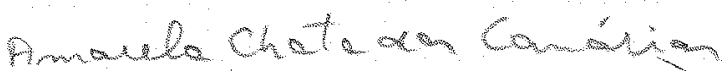

Texas Early Grano

Baia do Cedo

Baia do Cedo A SMJ-III

Baia do Cedo B SMJ-III

Composto Baia

Composto Baia SMJ-III

Baia Triunfo SMJ-I

Baia Triunfo SMJ-III

Neste experimento foram incluídas como testemunhas regionais as cultivares Amarela Chata das Canárias e Texas Early Grano. As cultivares Baia do Cedo e Composto Baia serviram para comparações com os seus ciclos mais avançados de seleção. Deve-se destacar o fato das semen tes utilizadas neste experimento terem sido produzidas no ano de 1978.

Os experimentos foram conduzidos em solos arenosos de origem aluviano, utilizando-se o sistema de plantio através de transplante de mudas em leirões com irrigação por infiltração. Os sulcos de irrigação ficaram distanciados de $0,80 \mathrm{~m}$. 


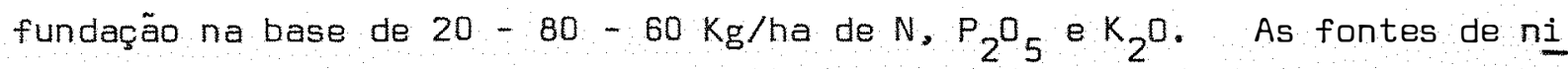
trogènio, fósforo e potássio foram Sulfato de Amônio, Superfosfato Simples e Cloreto de Potássio, respectivamente. Aos 15 e 30 dias após o transplante das mudas para os leirões foram feitas as adubações nitrogenadas em cobertura, utilizando-se $20 \mathrm{~kg} / \mathrm{ha}$ de $\mathrm{N}$ em cada aplicação. A fonte de nitrogênio foi o Sulfato de Amônio.

No decorrer dos experimentos foram realizados tratos cultu rais básicos, tais como aplicação de herbicida pós-transplante, irrigação por infiltração sempre que necessário, capinas manuais e tratos fitossanitários visando a prevenção de pragas e doenças da parte aérea. Os tratos culturais e fitossanitários foram eficientes, o que contribuiu para o bom andamento dos trabalhos, permitindo a obtenção de resultados satisfatórios.

Foram realizadas duas colheitas em cada experimento, sendo que a primeira foi iniciada quando mais de $70 \%$ das plantas se apresentavam em ponto de colheita comercial. Na segunda etapa foram colhidas todas as plantas remanescentes. Para fins de análise estatística, considerou-se o total obtido nas duas colheitas efetuadas.

\subsubsection{Procedimentos Estatisticos}

Os experimentos foram distribuídos num delineamento de blocos casualizados com seis repetições. Os experimentos I e II tiveram todos os doze tratamentos comuns, enquanto o III, com nove tratamentos, conteve apenas quatro tratamentos comuns aos anteriores. 
A unidade experimental foi constituída por dois leirões com uma ärea total de $6,0 \mathrm{~m}^{2}$ para uma lotação inicial de 300 plantas. Em cada leirão da parcela fez-se o transplante das mudas em três fileiras espaçadas $0,10 \mathrm{~m}$ entre si e $0,10 \mathrm{~m}$ entre plantas.

A análise da variáncia para todos os caracteres nos experimentos I e II obedeceu ao seguinte esquema:

Fontes de Variação

Repetições

Tratamentos (Populações)

Entre Grupos

Entre Grupos Baia

Test. vs. Grupos Baia

Ciclos $\mathrm{BC}_{\mathrm{B}}$

Ciclos $\mathrm{BC}_{\mathrm{A}}$

Regressão Linear/BC ${ }_{A}$

Regressão Quadrática/BC ${ }_{A}$

Ciclos CB

Regressão Linear/CB

Regressão Quadrática/CB

Ciclos BT

Regressão Linear/BT

Regressão Quadrática/BT
G.L.

05

11

04

03

01

01

02

01

01

02

01

01

02

01

01

Resíduo 
Para o experimento III a análise da variáncia obedeceu ao esquema:

Fontes de Variação

Repetições

Tratamentos

Resíduo
G.L.

05

08

40

O ganho realizado por ciclo de seleção dentro de cada Grupo Baia, para todos os caracteres avaliados nos experimentos I e II, foi obti do pelo coeficiente de regressão. Os coeficientes de regressão e as respectivas equações foram obtidas através de polinômiós ortogonais, de acordo com PIMENTEL GOMES (1970). O ganho realizado por ciclo de seleção foi representado graficamente.

Todos os dados de contagem foram transformados em $\sqrt{\text { número }}$ ou $\sqrt{\text { número }+0,5}$, conforme pode-se observar nas tabelas, seguindo recomendações de STEEL e TORRIE (1960). Para a estimação do ganho genético por ciclo de seleção, através da análise da regressão, considerou-se os valores biológicos não transformados. Foi utilizado o teste de Tukey ao ní vel de 5\% de probabilidade para a comparação de médias.

\subsubsection{Obtenção dos Dados Experimentais}


través da reunião deles foram avaliados. Os caracteres avaliados foram a produção, sobrevivência, bulbos comerciais, plantas improdutivas e bulbi nhos precoces. Para cada um desses caracteres foram utilizados os mesmos critérios adotados por MELO (1978), com exceção do mérito varietal:

a) Produção - Corresponde ao peso total de bulbos comerciais na parcela de $6,0 \mathrm{~m}^{2}$ de área, fazendo-se a transformação para toneladas por hectare, após terem sido eliminadas as raízes e folhas e antes da cura.

b) Sobrevivēncia - Expressa pelo número de plantas remanescentes por ocasião da colheita, para uma lotação inicial de 300 plantas por parcela de $6,0 \mathrm{~m}^{2}$.

c) Bulbos Comerciais - Representa o número de bulbos comerciais existentes na parcela de $6,0 \mathrm{~m}^{2}$, com uma lotação inicial de 300 plan tas. Procedeu-se à classificação desses bulbos em três categorias de peso: bulbos menores que $50 \mathrm{~g}$, entre 50 e $150 \mathrm{~g}$ e maiores que $150 \mathrm{~g}$.

d) Plantas Improdutivas - Corresponde ao nümero de plantas que não formaram bulbo até a colheita e que foram eliminadas.

e) Bulbinhos Precoces - Representa o nümero de plantas que formaram bulbos precocemente apös o transplante e com peso não superior a $20 \mathrm{~g}$.

f) Mérito Varietal - Critério adotado com a finalidade de reunir todas as características avaliadas nas populações de cebola em um 
índice empírico, que discerne o valor global das populações. Para a obtenção do mérito varietal caracterizou-se uma cultivar ideal para as condições climáticas e sistema de plantio utilizado nos experimentos. A cul tivar ideal seria aquela que numa população inicial de 500.000 plantas por hectare tivesse no final do ciclo $100 \%$ de sobrevivéncia, $100 \%$ de bulbos comerciais, cada bulbo pesando $100 \mathrm{~g}$, o que daria uma produtividade de 50 t/ha, zero \% de plantas improdutivas, zero \% de bulbinhos precoces e zero \% de plantas com escapo floral. Os dados obtidos em cada parcela para. esses caracteres foram tomados em porcentagem em relação a cultivar ideal e as proporções obtidas foram somadas, considerando-se com sinal positivo as proporções obtidas das características desejāveis de produção, sobrevivência e bulbos comerciais; e com sinal negativo:a das características indesejáveis de plantas improdutivas, bulbinhos precoces e plantas florescidas, segundo a fórmula:

$$
\text { M.V. }=\left(\frac{p}{50}+\frac{p s}{300}+\frac{b c}{300}\right)-\left(\frac{p i}{300}+\frac{b p}{300}+\frac{p f}{300}\right)
$$

onde, M.V. = mérito varietal; $p=$ produção em toneladas por hectare; ps = número de plantas sobreviventes por parcela; bc = número de bulbos comerciais por parcela; pi = número de plantas improdutivas por parcela; bp = número de bulbinhos precoces por parcela e pf = número de plantas florescidas .

Esta fórmula é válida para uma parcela com $6,0 \mathrm{~m}^{2}$ de área e 
uma lotação inicial de 300 plantas. A cultivar ideal obteria o valor 3,0. O mérito varietal pode alcançar o valor mínimo de $-1,0$ e um ideal de 3,0 ; podendo ultrapassar o valor ideal desde que se obtenha um valor máximo para todas as características desejáveis e o peso médio dos bulbos ultrapasse $100 \mathrm{~g}$. Após a verificação da normalidade dos valores obtidos para o mérito varietal procedeu-se à análise da variància. 


\section{RESULTADOS}

\subsection{Produção}

Para o caráter produção os resultados das análises da variància referentes aos Experimentos I, II e III encontram-se, respectivamente, nas tabelas 01, 02 e 03. Observou-se diferenças estatisticamente sig nificativas entre as populações de cebola nos três experimentos.

Quando as populações foram testadas nas condições de verão predominantes no Experimento I, detectou-se diferenças significativas para todas as decomposições de tratamentos realizadas. No cultivo de feverei ro-julho, Experimento II, obteve-se significáncia estatística apenas para regressão linear do Grupo Baia do Cedo A.

A análise da regressão para cíclos de seleção dos Grupos Baia do Cedo A e Baia Triunfo revelou efeitos lineares significativos no Experimento I (Tabela 01 e Figura 02). Os valores dos coeficientes de re gressão linear para ciclos $\mathrm{BC}_{\mathrm{A}}(\hat{\mathrm{B}}=3,7667)$ e $\mathrm{BT}(\hat{\mathrm{B}}=5,6333)$, indicam que ocorreu um acréscimo na produção por ciclo de seleção, a partir do prí 
meiro ciclo de seleção para Baia do Cedo $A$, de 3,7667 t/ha e 5,6333 t/ha para Baia Triunfo, a partir do ciclo original. Estes valores correspondem a um ganho de $91,46 \%$ e $171,21 \%$ em relação à produção média das populações BC ${ }_{A}$ SMJ-I e BT SMJ-O. Os ciclos de seleção do Composto Baia apresen taram efeitos quadráticos significativos, sendo de 172,73\% o ganho observa do após três ciclos de seleção em relação ao primeiro ciclo.

No Experimento II houve significância para efeitos lineares entre ciclos do Grupo Baia do Cedo $A$, que apresentou um coeficiente de regressão linear de valor - 4,4250, o que corresponde a um decréscimo na produção de bulbos comerciais da ordem de 4,4250 t/ha, evidenciando uma perda de produção de $24,11 \%$ em relação ao primeiro ciclo de seleção (Tabela 02 e Figura 03\}.

As médias de produção de bulbos comerciais em t/ha das popu lações, devidamente comparadas pelo teste de Tukey ao nível de 5\% de probą bilidade, relativas aos trés experimentos, encontram-se nas tabelas 04, 05 e 06 .

Ds ciclos de seleção do Grupo Baia do Cedo B, quando testa dos sob condições de verão, Experimento I, diferiram significativamente en tre si, sendo que o segundo ciclo de seleção produziu praticamente o dobro do primeiro ciclo. A produção da Baia do Cedo B SMJ-II foi comparável à da testemunha, assim como ao segundo ciclo de seleção das outras populações e ao terceiro ciclo de seleção da Baia do Cedo A e do Composto Baia. No Experimento III, realizado nas condições mais favoráveis de temperatura para a cultura da cebola no vale do Submédio São Francisco, a população 
$\mathrm{BC}_{B}$ SMJ-III foi estatisticamente inferior em produção a Amarela Chata das Canárias e superior à Baia Triunfo SMJ-III selecionada para as condições de verão, não diferindo das outras populações. Não foram detectadas dife renças significativas para o caráter produção nas populações testadas no Experimento II.

A Baia do Cedo A, selecionada para as condições de cultivo de fevereiro-julho, quando testada nas condições de verão, Experimento I, não apresentou diferenças significativas de produção entre os dois primeiros ciclos. O ciclo mais avançado de seleção, $\mathrm{BC}_{\mathrm{A}}$ SMJ-III, produziu praticamente o dobro de $\mathrm{BC}_{\mathrm{A}} \mathrm{SMJ}-\mathrm{I}$, não apresentando diferenças estatisticamen

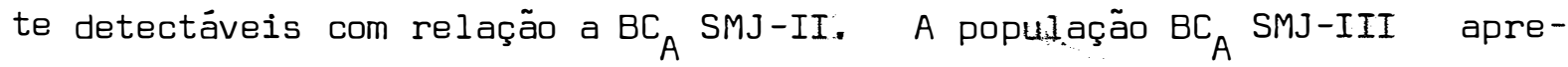
sentou uma produtividade comparável à testemunha e aos ciclos mais avançados das outras populações Baia quando cultivada nas condições de verão. No Experimento III, BC ${ }_{A}$ SMJ-III mostrou-se inferior apenas à testemunha, Amarela Chata das Canárias, comportando-se semelhantemente às outras populações quanto ao caráter produção.

Os ciclos de seleção Composto Baia SMJ-II e Composto Baía SMJ-III não diferiram estatisticamente entre si, quando cultivados sob con dições de verão. Ambos produziram quase trēs vezes mais que o primeiro ciclo de seleção, sendo superiores em produção de bulbos comerciais. terceiro ciclo de seleção, CB SMJ-III, não diferiu estatisticamente em pro dução da testemunha e dos ciclos de seleção II e III realizados nos Grupos Baia do Cedo A e B, apresentando-se, porém, estatisticamente inferior à Baia Triunfo SMJ-II. No Experimento III, realizado em condições climáticas favoráveis ao cultivo da cebola, CB SMJ-III mostrou-se estatisticamen- 
te superior em produção ao Composto Baia original e a Baia Triunfo SMJ-III selecionada para a época de temperaturas adversas.

Baia Triunfo SMJ-I e Baia Triunfo SMJ-II quando testadas sob condições de verão, para as quais foram selecionadas, apresentaram prọ dução estatisticamente equivalentes e superiores ao seu ciclo original. Baia Triunfo SMJ-0, originalmente selecionada por dois ciclos no período de fevereiro-julho, teve a produção estatisticamente comparável ao Composto Baia SMJ-III. A população BT SMJ-II apresentou produção equivalente à testemunha e aos ciclos mais avançados de seleção da Baia do Cedo A e B, apresentando-se estatisticamente superior ao Composto Baia SMJ-III. No experimento III, cultivo de inverno, BT SMJ-III apresentou-se inferior em produção à Amarela Chata das Canárias bem como ao terceiro ciclo de seleção dos Grupos Baia do Cedo B e Composto Baia.

\subsection{Sobrevivência}

Os resultados das análises da variância para o caráter sobrevivência, referentes aos Experimentos I, II e III, encontram-se, respec tivamente, nas tabelas 01, 02 e 03. Detectou-se diferenças significativas entre populações nas três épocas de cultivo. Todos os desdobramentos de tratamentos realizados no Experimento I apresentaram significáncia esta tística, assim como os realizados no Experimento II com exceção de Ciclos de seleção da Baia do Cedo B e Composto Baia.

Os ciclos de seleção dos Grupos Baia do Cedo A e Baia Triun 
fo, quando testados sob condições de verão, submetidos à análise da regres são, mostraram efeitos lineares significativos (Tabela 01 e Figura 04). Os valores dos coeficientes de regressão linear para ciclos de seleção dos Grupos Baia do Cedo $A(\hat{B}=17,0833)$ e Baia Triunfo $(\hat{B}=28,4167)$ mostraram que ocorreu um aumento do número de plantas sobreviventes, por parce la, da ordem de 17 plantas por ciclo de seleção, a partir do primeiro ciclo, para a Baia do Cedo A e de 28 plantas por ciclo de seleçãoja partir do ciclo original, para a Baia Triunfo. Os ciclos de seleção do Composto Baia apresentaram efeitos quadráticos significativos, sendo de $44,12 \%$ o au mento de plantas sobreviventes do terceiro ciclo de seleção em relação ao primeiro.

Quando as populações foram testadas no período de fevereiro julho, Experimento II, os ciclos de seleção do Composto Baia não diferiram estatisticamente entre si quanto ao caráter sobrevivência. Os ciclos de seleção dos Grupos Baia do Cedo A e Baia Triunfo apresentaram efeitos quadráticos significativos e com sinal negativo (Tabela 02 e Figura 05). Es tes resultados são conflitantes com os obtidos no experimento realizado sob condições de verão, onde estas populações mostraram ganhos substanciais no número de plantas sobreviventes por ciclo de seleção.

O nümero médio de plantas sobreviventes, por parcela com lo tação inicial de 300 plantas, nos Experimentos I, II e III encontram-se, respectivamente, nas tabelas 04, 05 e 06. Para a comparação das médias u tilizou-se o teste de Tukey ao nível de 5\% de probabilidade. 
II do Grupo Baia do Cedo B quanto ao caráter sobrevivência no cultivo de cebola sob condições de verão. $\mathrm{BC}_{B}$ SMJ-II mostrou um nível de sobrevivên cia bastante superior ao primeiro ciclo de seleção, mostrando-se equivalen te à testemunha e aos ciclos de seleção mais avançados das outras populações. No Experimento II, BC ${ }_{B} S M J-I$ e BC $B$ SMJ-II foram equivalentes e superiores ao segundo ciclo de seleção da Baia Triunfo,-mostrando-se inferio res apenas à testemunha. A população $B C_{B}$ SMJ-III quando cultivada sob condições de inverno, Experimento III, apresentou um nível de sobrevivência equivalente ao das outras populações testadas.

O Grupo Baia do Cedo A não apresentou diferenças significativas entre ciclos quanto ao caráter sobrevivéncìa, porém, revelou um aumento progressivo com os ciclos de seleção praticados, quando testado sob condições de verão. 0 ciclo de seleção mais avançado, $\mathrm{BC}_{\mathrm{A}} \mathrm{SMJ}$-III, teve comportamento idèntico à testemunha e aos ciclos mais avançados dos outros Grupos no Experimento I, mostrando-se estatisticamente superior ao primeiro ciclo de Baia do Cedo B e Composto Baia, além do Baia Triunfo original. No Experimento II, cultivo de fevereiro-julho, os ciclos $\mathrm{BC}_{A}$ apresentaram - mesmo nível de sobrevivência. BC ${ }_{A}$ SMJ-III diferiu significativamente a penas da seleção de verão, BT SMJ-II, mostrando-se bastante superior quanto à sobrevivência. No cultivo de inverno, Experimento III, BC ${ }_{A}$ SMJ-III mostrou-se superior apenas ao Composto Baia original, não diferindo estatisticamente das demais quanto ao caráter sobrevivéncia.

No cultivo de verão, Experimento I, os ciclos de seleção do Composto Baia apresentaram uma tendēncia marcante em aumentar a sobrevi vência com a seleção praticada. Os dois ciclos mais avançados não diferí 
ram entre si, mostrando-se superiores ao primeiro ciclo de seleção. SMJ-III não diferiu significativamente da testemunha e dos ciclos II e III das outras populações selecionadas. No cultivo de fevereiro-julho o terceiro ciclo de seleção do Composto Baia, CB SMJ-III, mostrou uma sobrevivência superior a de Baia Triunfo SMJ-II e inferior à testemunha. No experimento III, CB SMJ-III foi superior apenas ao Composto Baia ariginal. apresentando um excelente ganho quanto ao carāter sobrevivência, sem contú do diferir das demais populações.

Os ciclos de seleção I e II realizados na Baia Triunfo, quando testados nas condições de verão, não apresentaram diferenças significativas quanto ao caráter sobrevivência, mostrando-se superiores à culti var Baia Triunfo da qual foram obtidos. BT SMJ-II apresentou uma sobrevi véncia superior à da testemunha, Amarela Chata das Cánárias, não diferindo dos ciclos mais avançados de seleção das outras populações Baia. No experimento II, os ciclos de seleção da Baia Triunfo não diferiram entre si, porém, o segundo ciclo mostrou uma sobrevivência bastante inferior à da testemunha e das outras populações selecionadas em cultivo de fevereirojulho. Nas condições de inverno, Experimento III, BT SMJ-III teve uma sobrevivência equivalente à das testemunhas e dos ciclos mais avançados da seleção das outras cultivares.

\subsection{Bulbos Comerciais}

O nümero de bulbos comerciais por parcela é um dos caracteres mais importantes na avaliação de populações de cebola. Os resultados 
da análise da variāncia para este caráter, nos Experimentos I, II e III en contram-se nas tabelas 01, 02 e 03, respectivamente. Detectou-se diferen ças significativas entre populações para o caráter bulbos comerciais nas très épocas de cultivo. As decomposições realizadas no Experimento I apresentaram efeitos significativos, mostrando que sob condições de veräo, os Grupos, assim como os ciclos de seleção, comportam-se diferencialmente. No Experimento II, cultivo de fevereiro-julho, encontrou-se diferenças entre Grupos e entre ciclos dos Grupos Baia do Cedo A e Baia Triunfo.

As análises da regressão detectaram efeitos lineares significativos para ciclos de seleção nos Grupos Baia do Cedo A e Baia Triunfo, sob condições de verão (Tabela 01). Os valores dos coeficientes de regressão linear para ciclos de seleção dos Grupos Baia do Cedo $A$ Ć $=$ 38,9167) e Baia Triunfo $(\hat{b}=54,6667)$ evidenciam a ocorrência de aumento do número de bulbos comerciais, por parcela, a partir do primeiro ciclo de seleção, da ordem de 78,00\% para Baia do Cedo A e 122,47\% para a Baia Triunfo, a partir da população original (Figura 06). 0 Composto Baia apresentou efeitos quadráticos significativos, sendo de $147,45 \%$ o aumento do número de bulbos comerciais por parcela entre o primeiro e terceiros ciclos de seleção.

No Experimento II detectou-se efeitos lineares significativos para o caráter número de bulbos comercīais nos Grupos Baia do Cedo A e Baia Triunfo. Os valores dos coeficientes de regressão linear dos Grupos Baia do Cedo $A(\hat{b}=-23,5833)$ e Baia Triunfo $(\hat{b}=-25,8333)$ mostram que ocorreu uma diminuição do número de bulbos comerciais por parcela da ordem de $25,82 \%$ e $46,21 \%$, respectivamente (Tabela 02 e Figura 07 ). Estes 
resultados não estão de acordo com os obtidos sob condições de verão, onde estes grupos apresentaram um aumento considerável do número de bulbos comerciais por ciclo de seleção.

0 número médio de bulbos comerciais, por parcela com lotação inicial de 300 plantas, dos Experimentos I, II e III encontram-se, res pectivamente, nas tabelas 04, 05 e 06. Para a comparação das médias utilizou-se o teste de Tukey ao nível de 5\% de probabilidade.

O segundo ciclo de seleção no Grupo Baia do Cedo B produziu um número de bulbos comerciais equivalente ao da testemunha e dos ciclos mais avançados dos outros Grupos, quando cultivados sob condições de verão. No Experimento II a população BC $B$ SMJ-II não diferiu significativamente das demais. No cultivo sob condições de inverno, o terceiro ciclo de seleção massal no Grupo Baia do Cedo B produziu significativamente mais bulbos comerciais por parcela que o terceiro ciclo de seleção na Baia Triun fo, não diferindo das outras populações de cebola que participaram desse experimento.

A população Baia do Cedo A SMJ-III não diferiu significativamente, quanto ao número de bulbos comerciais por parcela, da testemunha e dos ciclos mais avançados de seleção dos outros Grupos, quando cultivada sob condições de verão, mostrando-se superior à Baia Triunfo original e aos primeiros ciclos de todos os Grupos submetidos à seleção. No cultivo de fevereiro-julho não diferiu significativamente das demais. No Experimento III, cultivo de inverno, mostrou-se superior apenas à Baia Triun fo SMJ-III. 
O terceiro ciclo de seleção no Composto Baia produziu um nū mero de bulbos comerciais equivalente ao da testemunha e dos ciclos mais a vançados dos Grupos Baia do Cedo A e Baia do Cedo B, mostrando-se inferior à Baia Triunfo SMJ-II, quando cultivada sob condições de verão do Experimento I. No cultivo de fevereiro-julho, Experimento II, CB SMJ-III apresentou um número de bulbos comerciais equivalente ao das outras populações porém. CB SMJ-II mostrou-se inferior à Baia do Cedo' A SMJ-I. No Experimento III, sob condições de inverno, CB SMJ-III mostrou-se superior, quanto à produção de bulbos comerciais, à Baia Triunfo SMJ-III, selecionada para condições de altas temperaturas.

A população Baia Triunfo SMJ-II, sẹlecionada para condições de temperaturas elevadas, foi a que produziu o maior número de bulbos comerciais por parcela, quando cultivada sob condições de verão. BT SMJ-II mostrou-se equivalente à testemunha, à $B T S M J-I, B C_{B} S M J-I I$ e $B C_{A} S M J-I I I$, e superior às demais. No Experimento II, cultivo de fevereiro-julho, BT SMJ-II produziu um número de bulbos comerciais inferior ao da Amarela Chata das Canárias e do primeiro ciclo de seleção da Baía do Cedo A e Composto Baia. A Baia Triunfo SMJ-III quando cultivada sob condições de inverno, Experimento III, foi a população que produziu o menor número de bulbos comerciais, mostrando-se estatisticamente inferior às demais, apesar de ter um alto nível de sobrevivência pós-transplante.

\subsubsection{Bulbos Comerciais de Peso Inferior a $50 \mathrm{~g}$}

A classificação dos bulbos comerciais por categoria de peso, quando analisada estatisticamente, mostrou que as populações diferem 
entre si quanto à produção de bulbos menores que $50 \mathrm{~g}$, nas trés épocas de cultivo. Os resultados das análises de variäncia encontram-se nas tabelas 07,08 e 09.

Sob condições de verão, Experimento I, detectou-se diferenças significativas entre ciclos de seleção para todos os Grupos. No expe rịmento II, cultivo de fevereiro-julho, encontrou-se diferenças Entre Grupos e para o seu desdobramento em Entre Grupos Baia e Testemunha vs. Grupos Baia, também, para ciclos de seleção dos Grupos Composto Baia e Baia Triunfo.

A análise da regressão mostrou a existência de efeitos line 2. ares para ciclos Baia do Cedo A e Baia Triunfo, enquanto os ciclos do Composto Baia apresentaram efeitos quadráticos para número de bulbos por parcela menores que 50 g (Tabela 07), sob condições de verão. 0 aumento do número de bulbos comerciais pequenos por ciclo de seleção, característica indesejável em relação às outras categorias de peso, foi determinado pelo coeficiente de regressão linear. Baia do Cedo A apresentou um aumento de 13 bulbos/parcela/ciclo de seleção a partir do primeiro ciclo e Baia Triun fo aumentou 23 bulbos/parcela/ciclo de seleção, a partir do ciclo original (Figura 08). No Experimento II constatou-se a ocorréncia de efeitos line ares para ciclos de seleção nos Grupos Composto Baia e Baia Triunfo, apresentando um decréscimo de 07 e 17 bulbos de peso inferior a $50 \mathrm{~g}$ por parce la e por ciclo de seleção, respectivamente (Figura 09).

0 nümero médio de bulbos comerciais menores que $50 \mathrm{~g}$, devidamente comparados pelo teste de Tukey ao nivel de $5 \%$ de probabilidade, 
referente aos Experimentos I, II e III, encontram-se nas tabela 10, 11 e 12, respectivamente.

A população Baia do Cedo B SMJ-II apresentou, estatisticamente, um maior número de bulbos pequenos por parcela que o seu primeiro ciclo de seleção, sob condições de verão. Mostrou produção inferior apenas ao Composto Baia SMJ-I e Baia Triunfo SMJ-II. No Experimento II, $\mathrm{BC}_{\mathrm{B}}$ SMJ-II produziu significativamente mais bulbos pequenos que BT SMJ-II e menos que Amarela Chata das Canárias. Sob condições de inverno, Experi mento III, $\mathrm{BC}_{B}$ SMJ-III apresentou, significativamente, um maior nūmero de bulbos pequenos que BT SMJ-III e menor que Texas Early Grano e Composto Baia original.

Sob condições de temperaturas elevadas, Experimento I, o terceiro ciclo de seleção do Grupo Baia do Cedo A produziu mais bulbos pequenos que o primeiro ciclo de seleção dos Grupos Baia do Cedo B e Composto Baia, não diferindo estatisticamente das demais. No Experimento II, $\mathrm{BC}_{\mathrm{A}}$ SMJ-III apresentou significativamente menos bulbos de peso inferior a $50 \mathrm{~g}$ que a testemunha e mais que BT SMJ-II. Sob condições de inverno, Experimento III, $\mathrm{BC}_{A}$ SMJ-III produziu mais bulbos pequenos que BT SMJ-III e menos que Texas Early Grano.

Com relação ao nümero de bulbos pequenos o Composto Baia SMJ-III teve, estatisticamente, o mesmo comportamento que a população Baia do Cedo A SMJ-III. Este comportamento era esperado, pois, ambos foram se lecionados na mesma época e estavam no mesmo ciclo de seleção. 
A população Baia Triunfo SMJ-II, selecionada para condições de verão, quando testada nessa mesma época de cultivo, apresentou o maior número de bulbos pequenos, sendo estatisticamente superior “à testemunha, ao primeiro ciclo de seleção dos outros Grupos Baia e ao seu ciclo original. Nos Experimentos II e III, BT SMJ-II e BT SMJ-III produziram, respectivamente, o menor número de bulbos pequenos, evidenciando o comportamento diferencial das seleções de verão quando cultivadas em outras épocas de plantio.

\subsubsection{BuTbos Comerciais de Peso entre 50 e $150 \mathrm{~g}$}

As populações testadas nas três éppocas de cultivo apresenta ram diferenças significativas quanto ao número de bụlbos de tamanho médio, considerados os de melhor aceitação comercial. As tabelas 07, 08 e 09 apresentam os resultados da análise da variância dos Experimentos I, II e III, respectivamente.

Todas as decomposições de tratamentos do Experimento I foram estatisticamente significativas, enquanto o Experimento II apresentou significância apenas Entre Grupos e para ciclos do Grupo Baia do Cedo A,pa ra número de bulbos médios.

No cultivo de verão, Experimento I, a análise da regressão detectou efeitos lineares significativos para ciclos de seleção dos Grupos Baia do Cedo A e Baia Triunfo (Tabela 07). Os valores dos coeficientes de regressão para Ciclos $B C_{A}(\hat{B}=25,1667)$ e $B T(\bar{B}=30,7500)$, mostram que ocorreu. um aumento do número de bulbos médios de 25 bulbos/parcela/ci- 
clo de seleção, a partir do primeiro ciclo, para Baia do Cedo A e de 31 bulbos/parcela/ciclo de seleção, a partir do ciclo original, para Baia Tri unfo (Figura 10). O Composto Baia apresentou efeitos quadráticos signifi cativos para número de bulbos médios por ciclo de seleção. No cultivo de fevereiro-julho, Experimento II, apenas Baia Triunfo apresentou efeitos lineares significativos, apresentando um decréscimo, determinado pelo coeficiente de regressão, de 16 bulbos/parcela/ciclo de seleção a partir do ciclo original (Figura 11).

Nas tabelas 10, 11 e 12 encontram-se o nümero médio de bulbos comerciais de 50 a 150 g, por parcela com lotação inicial de 300 plantas, referente aos Experimentos I, II e III, respectivamente. Para a com paração das médias utilizou-se o teste de Tukey, ao nível de 5\% de probabi lidade.

No Experimento I, cultivo de verão, a população Baia do Cedo B SMJ-II produziu significativamente mais bulbos de tamanho médio que Baia Triunfo original e Composto Baia SMJ-I, sem contudo diferir das demais. No cultivo de fevereiro-julho, BC $B$ SMJ-II não diferiu estatisticamente das demais populações quanto ao nümero de bulbos entre 50 e $150 \mathrm{~g}$. Sob condições de inverno, Experimento III, BC ${ }_{B}$ SMJ-III mostrou-se superior ao Composto Baia original e ao terceiro ciclo de seleção da Baia Triunfo.

A população Baia do Cedo A SMJ-III, sob condições de temperaturas elevadas, Experimento I, foi estatisticamente superior à Baia Triunfo original e ao primeiro ciclo de seleção das outras populações selecio nadas, quanto à produção de bulbos de tamanho médio. No cultivo de 
fevereiro-julho não diferiu significativamente das outras populações. Sob condições de inverno a população $\mathrm{BC}_{\dot{A}}$ SMJ-III produziu significativamente mais bulbos de tamanho médio que Baia Triunfo SMJ-III.

0 Composto Baia SMJ-III no Experimento I diferiu estatisticamente apenas do seu primeiro ciclo de seleção, quanto ao nümero de bulbos entre 50 e 150 g por parcela. Não diferiu das outras populações quan do testado no cultivo de fevereiro-julho. A população CB SMJ-III quando cultivada sob condições de inverno comportou-se diferencialmente e de modo superior ao Composto Baia original e da Baia Triunfo SMJ-III, quanto à pro dução de bulbos com peso de 50 a $150 \mathrm{~g}$.

No cultivo de verão, Experimento I, a população Baia Triunfo SMJ-II foi a que produziul o maior número de bulbas com peso entre 50 e $150 \mathrm{~g}$, não diferindo significativamente da testemunha e dos ciclos de sele ção II e III dos outros Grupos Baia. No cultivo de fevereiro-julho, Expe rimento II, apresentou significativamente menos bulbos médios que a testemunha e Baia do Cedo A SMJ-I. No cultivo de inverno, Experimento III, BT SMJ-III produziu, estatisticamente, menos bulbos de tamanho médio que Amarela Chata das Canárias, Baia do Cedo original e o terceiro ciclo de seleção dos outros Grupos Baia.

\subsubsection{Bulbos Comerciais de Peso Superior a $150 \mathrm{~g}$}

A produção de bulbos comerciais de peso maior que $150 \mathrm{~g}$ é uma característica populacional muito influenciada pelo ambiente, não podendo ser considerada indesejável, uma vez que pode ser manipulada pelo 
controle da densidade de plantas, com a finalidade de diminuir o tamanho. Os resultados da análise da variáncia dos Experimentos I, II e III encontram-se, respectivamente, nas tabelas 07,08 e 09.

A análise da variância detectou diferenças significativas entre populações nas épocas extremas de temperatura, cultivo de verão e cultivo de inverno, não determinando diferenças no cultivo de fevereirojulho. Após a decomposição de tratamentos, notou-se diferenças apenas en tre Grupos, sendo que os Grupos Baia não diferiram entre si, mas diferiram da testemunha no cultivo de verão, quanto ao número de bulbos grandes por parcela.

o número médio de bulbos comerciais com peso superior a 150 g dos Experimentos I, II e III encontram-se, respectivamente, nas tabelas 10, 11 e 12. Para a comparação das médias utilizou-se o teste de Tukey ao nível de 5\% de probabilidade.

Sob condições de verão, Experimento I, Amarela Chata das Canárias não diferiu significativamente, quanto à produção de bulbos grandes, do segundo ciclo de seleção dos Grupos Baia do Cedo A, Baia do Cedo B e Composto Baia, mostrando-se superior às demais populações. No Experimento III, cultivo de inverno, Amarela Chata das Canárias mostrou-se estatisticamente superior a todas as populações testadas, sendo que estas produziram quantidades equivalentes de bulbos maiores que $150 \mathrm{~g}$. 


\subsection{Plantas Improdutivas}

Os valores e significáncias dos quadrados médios para o caráter plantas improdutivas nos Experimentos I, II e III encontram-se, respectivamente, nas tabelas 01, 02 e 03. Detectou-se diferenças significativas entre populações nas três épocas de cultivo.

A decomposição de tratamentos realizada no. Experimento I mostrou significância apenas Entre Grupos e para ciclos de seleção do Grupo Baia Triunfo. No cultivo de fevereiro-julho, Experimento II, os ciclos de seleção dos Grupos Baia do Cedo A, Composto Baia e Baia Triunfo apresentaram-se estatisticamente diferentes quanto ao caráter plantas impro dutivas.

O Grupo Baia Triunfo quando testado no cultivo de verão, Ex perimento I, apresentou efeitos quadráticos significativos quando submetido à análise da regressão (Tabela 01 e Figura 12). Após dois ciclos de seleção sob condições de verão, na cultivar Baia Triunfo, ocorreu um de créscimo de plantas improdutivas por parcela, da ordem de $81,82 \%$. No cul tivo de fevereiro-julho, Experimento II, a análise da regressão detectou efeitos Iineares significativos para ciclos do Grupo Baia do Cedo A e quadráticos para ciclos dos Grupos Composto Baia e Baia Triunfo (Tabela 02 e Figura 131. Nas populações BC A SMJ-III e CB SMJ-III ocorreu um aumento de 96,65\% e 44,83\% no número de plantas improdutivas por parcela em relaÇão ao primeiro ciclo de seleção, enquanto BT SMJ-II aumentou de $90,48 \%$ o número de plantas improdutivas por parcela em relação ao seu ciclo original, quando testada no cultivo de fevereiro-julho. 
Nas tabelas 04, 05 e 06 encontram-se o nümero médio de plan tas improdutivas por parcela dos Experimentos I, II e III, respectivamen te. Para a comparação das médias foi utilizado o teste de Tukey ao nível de $5 \%$ de probabilidade.

Os ciclos de seleção do Grupo Baia do Cedo B não diferiram significativamente, quanto ao número de plantas improdutivas, nas três épo cas de cultivo. Sob condições de verão, Experimento I, BC $B$ SMJ-II diferiu significativamente apenas da Baia Triunfo SMJ-I, apresentando um menor número de plantas improdutivas. No Experimento II, BC ${ }_{B}$ SMJ-II não apresentou diferenças significativas quanto ao número de plantas improdutivas, em relação às outras populações. No cultivo de inverno a população BC ${ }_{B}$ SMJ-III apresentou significativamente mais plantas improdutivas que Texas Early Grano e menos que Baia Triunfo SMJ-III.

Nos Experimentos I e II a população Baia do Cedo A SMJ-III não apresentou diferenças significativas quanto ao número de plantas impro dutivas, em relação às outras populações ensaiadas. No cultivo de inverno, Experimento III, a população BC ${ }_{A}$ SMJ-III apresentou significativamente mais plantas improdutivas que as duas testemunhas, Amarela Chata das Canárias e Texas Early Grano, e as duas populações originais Baia do Cedo e Composto Baia. Só o terceiro ciclo de seleção da Baia Triunfo foi que produziu significativamente mais plantas improdutivas que $B C_{A} S M J-I I I$, sob condições de inverno.

O terceiro ciclo de seleção do Composto Baia, CB SMJ-III, a presentou significativamente menos plantas improdutivas que Baia Triunfo 
SMJ-I, näo diferindo das demais quando cultivado sob condições de verao. No cultivo de fevereiro-julho, Experimento II, a população Composto Baia SMJ-III mostrou comportamento equivalente ao das outras populações quanto ao número de plantas improdutivas. Sob condições de inverno, Experimento III, CB SMJ-III apresentou, estatisticamente, mais plantas improdutivas que - Composto Baia original e as duas testemunhas, Amarela Chata das Canárias e Texas Early Grano. Baía Triunfo SMJ-III produziu cerca de trés vezes mais plantas improdutivas que CB SMJ-III no cultivo de inverno.

A população Baia Triunfo SMJ-II, com relação ao caráter plantas improdutivas, não diferiu estatisticamente das outras populações testadas nos Experimentos I e II. No cultivo de inverno o terceiro ciclo de seleção da Baia Triunfo, BT SMJ-III, apresentou mais de 50\% de plantas improdutivas, suplantando todas populações testadas. Esta ocorréncia evi dencia a não adaptação dessa população ao cultivo de inverno.

\subsection{Bulbinhos Precoces}

As populações testadas nas três épocas de cultivo de cebola no vale do Submédio São Francisco, apresentaram diferenças significativas em relação ao caráter bulbinhos precoces. Os valores e significäncias dos quadrados médios para número de bulbinhos precoces por parcela, nos Ex perimentos I, II e III encontram-se, respectivamente, nas tabelas 01, 02 e 03.

Todas as decomposições de tratamentos realizadas nos Experi mentos I e II mostraram significāncia estatística, com exceção de ciclos 
Baia do Cedo B, que não diferiu significativamente nos dois experimentos com relação ao número de bulbinhos precoces.

A anālise da regressão detectou efeitos lineares significativos para ciclos de seleção nos Grupos Baia do Cedo A e Baia Triunfo no cultivo de verão. O decréscimo do número de bulbinhos precoces por ciclo de seleção, numa parcela com lotação inicial de 300 plantas, foi encontrado pelo coeficiente de regressão linear. Para o Grupo Baia do Cedo A ocorreu um decréścimo de 24 bulbinhos precoces por ciclo de seleção a partir do primeiro ciclo, o que corresponde a uma diminuição de $96,00 \%$ após três ciclos de seleção. O grupo Baia Triunfo apresentou um decréscimo de 31 bulbinhos precoces por ciclo de seleção a partị do ciclo original, o que corresponde a um decréscimo de $155,00 \%$ de bulbiṇhos após dois ciclos de seleção. O Composto Baia apresentou efeitos quadráticos significativos, sendo de $15,73 \%$ o decréscimo do nümero de bulbinhos precoces no terceiro ciclo de seleção em relação ao primeiro ciclo (Figura 14).

No Experimento II, cultivo de fevereiro-julho, a análise de regressão para número de bulbinhos precoces por ciclo de seleção, detectou efeitos lineares significativos para ciclos de seleção do Grupo Baia do Ce do A e Baia Triunfo. Os coeficientes de regressão linear para BC ${ }_{A}$ $(\bar{G}=-2,5833)$ e BT $(G=-2,3333)$, indicam que ocorreu um decréscimo do número de bulbinhos precoces por parcela e por ciclo de seleção de 02 e 03 , respectivamente. 0 Grupo Composto Baia apresentou efeitos quadráticos significativos, sendo cerca de doze vezes o decréscimo de bulbinhos precoces por parcela do terceiro ciclo em relação ao primeiro ciclo de seleção (Figura 15). 
O nümero médio de bulbinhos precoces por parcela dos Experi mentos I, II e III encontram-se nas tabelas 04, 05 e 06, respectivamente. Para a comparaçao das médias foi aplicado o teste de Tukey ao nível de 5\% de probabilidade.

o experimento realizado sob condições de temperaturas eleva das foi o que apresentou o maior número de bulbinhos precoces, mostrando uma variação de 40 a 103 bulbinhos precoces por parcela entre as populações.

A população Baia do Cedo B SMJ-II quando cultivada sob condições de verão, Experimento I, mostrou uma produção de bulbinhos precoces significativamente inferior aos ciclos de seleção I e III do Composto Baia e ao ciclo original da Baia Triunfo, sem diferir das demais. No cultivo de fevereiro-julho apenas Composto Baia SMJ-I produziu, significativamente mais bulbinhos precoces que $\mathrm{BC}_{\mathrm{B}}$ SMJ-II. No Experimento III, cultivo de inverno, ${ }^{B C} C_{B}$ SMJ-III produziu estatisticamente, menos bulbinhos precoces que os ciclos originais do Composto Baia e Baia do Cedo, além da testemunha Texas Early Grano.

No cultivo de verão, Experimento I, a população Baia do Cedo A SMJ-III produziu significativamente menos bulbinhos precoces que os dois primeiros ciclos de seleção. Apresentou também menos bulbinhos que os ciclos I e III do Composto Baia e ciclo original da Baia Triunfo. No Experimento II, cultivo de fevereiro-março, ${ }^{B C}{ }_{A}$ SMJ-III diferiu significativamente apenas do Composto Baia SMJ-I, cuja população produziu o maior número de bulbinhos precoces. No cultivo de inverno, BC $\mathrm{A}_{\mathrm{A}}$ SMJ-III não di- 
feriu das outras populações selecionadas e de Amarela Chata das Canárias, mostrando uma menor produção de bulbinhos precoces em relação aos ciclos originais da Baia do Cedo e Composto Baia, além de Texas Early Grano.

A maior produção de bulbinhos precoces no Experimento I foi alcançada pela população Composto Baia SMJ-I, produzindo significativamente mais que o segundo ciclo de seleção e não diferindo significativamente do Composto Baia SMJ-III. Em relação às outras populações, CB SMJ-III não diferiu dos dois primeiros ciclos de seleção da Baia do Cedo $A$ e da Baia Triunfo SMJ-0, produzindo significativamente mais bulbinhos precoces que as outras populações. No cultivo de fevereiro-julho, CB SMJ-III diferiu significativamente apenas do seu primeiro ciclọ de seleção que, semelhantemente ao cultivo de verão, foi a população que produziu o maior núme ro de bulbinhos precoces por parcela. No Experimento III, cultivo de inverno, CB SMJ-III produziu significativamente menos bulbinhos precoces que Composto Baia original e Texas Early Grano, não diferindo das demais populações testadas.

A menor produção de bulbinhos precoces por parcela, no cultivo de verão, foi obtida pela população Baia Triunfo SMJ-II, selecionada para condições de temperaturas elevadas. BT SMJ-II não diferiu estatisti camente de Amarela Chata das Canárias, Baia do Cedo B SMJ-II, Baia do Cedo A SMJ-III e do seu primeiro ciclo de seleção, no Experimento I. De uma maneira geral, a produção de bulbinhos precoces foi muito pequena no culti vo de fevereiro-julho, sendo que Composto Baia SMJ-I produziu uma média de 12 bulbinhos por parcela, enquanto BT SMJ-II mostrou auséncia de bulbifica ção precoce pós-transplante. No cultivo de inverno, Experimento III, o 
terceiro ciclo de seleção dos Grupos Baia Triunfo, Baia do Cedo A, Baia do Cedo B e Composto Baia, apresentaram comportamento estatisticamente idênti co quanto à formação de bulbinhos precoces, não diferindo da testemunha, Amarela Chata das Canárias.

\subsection{Mérito Varietal}

O mérito varietal, que é um índice envolvendo todas as características avaliadas, define o valor global das populações. Os valores e significâncias dos quadrados médios para o mérito varietal encontrado nos Experimentos I, II e III encontram-se, respectivamente, nas tabelas 01,02 e 03.

A análise da variância detectou diferenças significativas para o mérito varietal das populações nos três experimentos. Realizada a decomposição de tratamentos no Experimento I, cultivo de verão, encontrou-se significáncia estatística para todos os desdobramentos realizados. No Experimento II, cultivo de fevereiro-julho, a decomposição de tratamentos mostrou significância apenas Entre Grupos e para ciclos de seleção do Grupo Baia do Cedo A.

A anālise da regressão detectou efeitos lineares significativos para ciclos de seleção dos Grupos Baia do Cedo A e Baia Triunfo. Os coeficientes de regressão para Baia do Cedo $A(\hat{b}=0,3375)$ e Baia Triunfo $(\hat{B}=0,4790)$, mostraram que houve um ganho de 0,3375 e 0,4790 unidade do mérito varietal por ciclo de seleção, respectivamente. Estes valores cor 
respondem a um ganho de $26,91 \%$ por ciclo de seleção para $\mathrm{BC}_{A}$ a partir do primeiro ciclo de seleção e de $32,00 \%$ para Baia Triunfo a partir da popula ção original, sob condiçães de temperaturas elevadas predominantes no Experimento I. O Grupo Composto Baia apresentou efeitos quadráticos significativos, sendo de 0,74 unidade o aumento do mérito varietal após três ciclos de seleção em relação ao primeiro ciclo (Tabela 01 e Figura 16). No cultivo de fevereiro-julho, Experimento II, apenas detectou-se efeitos lineares significativos para ciclos de seleção do Grupo Baia do Cedo A. O coeficiente de regressão para ciclos de seleção do -Grupo Baia do Cedo A $l \hat{b}=-0,2450$ mostrou um decréscimo de 0,2450 unidade do mérito varietal por ciclo de seleção a partir do primeiro cicla (Tabela 02 e Figura 17).

0 valor médio do mérito varietal das populações testadas nos Experimentos I, II e III encontra-se, respectivamente, nas tabelas 04, 05 e 06. Para a comparação das médias utilizou-se o teste de Tukey ao nível de $5 \%$ de probabilidade.

No cultivo de verão, Experimento I, a população Baia do Cedo B SMJ-II apresentou um mérito varietal significativamente superior ao do seu primeiro ciclo de seleção, assim como à Baia Triunfo original e ao primeiro ciclo de seleção dos Grupos Baia do Cedo A e Composto Baia, não diferindo das demais populações. No Experimento II, cultivo de fevereiro julho, $\mathrm{BC}_{\mathrm{B}}$ SMJ-II apresentou um mérito varietal equivalente ao das outras populações testadas. Sob condições de inverno, Experimento III, BC ${ }_{B}$ SMJIII conseguiu suplantar significativamente, apenas a população Baia Triunfo SMJ-III quanto ao mérito varietal, não diferindo das demais. 
A população Baia do Cedo A SMJ-III, sob condições de verão, mostrou-se significativamente superior, quanto ao mérito varietal, ao seu primeiro ciclo de seleção, à Baia Triunfo SMJ-0. e ao primeiro ciclo de seleção da Baia do Cedo B e Composto Baia. No cultivo de fevereiro-julho, Experimento II, BC ${ }_{A}$ SMJ-III não diferiu estatisticamente das outras popula ções. Deve-se salientar que neste experimento, $\mathrm{BC}_{A}$ SMJ-III apresentou um mérito varietal inferior ao do seu primeiro ciclo de seleção. No Experi mento III, cultivo de inverno, $\mathrm{BC}_{\mathrm{A}}$ SMJ-III apresentou um mérito varietal estatisticamente superior ao de Baia Triunfo SMJ-III e inferior ao de Amarela Chata das Canárìas.

No Experimento I, cultivo de verão, o Composto Baia SMJ-III apresentou um mérito varietal significativamente superior ao do primeiro ciclo de seleção dos Grupos Composto Baia, Baia do Cedo A e Baia do Cedo B além do ciclo original da Baia Triunfo. Sob condições de verão CB SMJIII obteve um mérito varietal estatisticamente inferior apenas à população Baia Triunfo SMJ-II. No Experimento II CB SMJ-III não diferiu significativamente das outras populações testadas. No cultivo de inverno, Experimento III, CB SMJ-III obteve um mérito varietal estatisticamente superior ao da Baia Triunfo SMJ-III e do seu ciclo original.

A população Baia Triunfo SMJ-II foi a que apresentou o maior valor para mérito varietal quando cultivada sob condições de verão. BT SMJ-II mostrou-se superior a todas as populações testadas, com exceção da Baia do Cedo A SMJ-III e Baia do Cedo B SMJ-II, que não apresentaram diferenças significativas. No Experimento II, cultivo de fevereiro-julho, 
BT SMJ-II obteve um mérito varietal estatisticamente inferior ao da testemunha, Amarela Chata das Canárias, e da população Baia do Cedo A SMJ-I, não diferindo das demais. No cultivo de inverno, Experimento III,Baia Triunfo SMJ-III, selecionada para condições de temperaturas elevadas, foi a população que apresentou o menor valor para mérito varietal, igualandose estatisticamente apenas ao Composto Baia original. 


\section{DISCUSSAOO}

0 Vale do Submédio São Francisco, situado numa faixa de la titude entre $8^{\circ}$ e $9^{\circ}$ Sul, destaca-se como uma das raras regiões tropicais em que se cultiva cebola o ano inteiro, devido às suas peculiaridades cli máticas. A região se caracteriza por apresentar clima semi-árido, fotoperíodo praticamente constante, em torno de 12:00 horas, com variação des prezível e temperatura média anual em torno de $27^{\circ} \mathrm{C}$. A média das temperaturas mínimas situa-se ao redor de $21^{\circ} \mathrm{C}$ e a das máximas entre $32^{\circ}$ e 33 ${ }^{\circ} \mathrm{C}$ (Figura 01). Nestas condições, o fator temperatura assume importáncia fundamental na adaptação de cultivares de cebola. Ao contrário, nas regiões de clima temperado, segundo HEATH (1945), a temperatura tem somente a função secundária de alterar o período de maturação, sendo o fotoperíodo o fator decisivo e primário.

Populações de cebola de dias curtos apresentaram comportamento diferencial relativo às épocas de cultivo, definidas pela variação de temperatura no Vale do Submédio São Francisco. A produtividade das populações de cebola mostrou que a época de cultivo constitui o fator li- 
mitante e crítico para as cultivares de dias curtos. A cultivar Amarela Chata das Canárias por ser cultivada o ano todo e por vários anos, tanto por cebolicultores como nas estações experimentais situadas na região, foi utilizada como padrão. Sob o ponto de vista do melhoramento, o objetivo é a obtenção de populações do Grupo Baia Periforme, com um comportamento equivalente ou superior à Amarela Chata das Canárias, sem as suas limitações de susceptibilidade às doenças e qualidade de conservação de bulbos. No cultivo de fevereiro-julho a produção da testemunha foi duas vezes maior que a obtida no cultivo de verão, concordando com os resultados de MELO (1978). No cultivo de inverno a produção de bulbos comerciais foi o triplo em relação à obtida sob condições de temperaturas elevadas predominantes no cultivo de verão. Postula-se que a temperatura seja o fator limitante no cultivo de verão, contribuindo para a redução da produtividade, evidenciada pela maior ocorréncia de bulbinhos precoces, menor sobrevivência e menor nümero de bulbos comerciais. Cerca de 50\% dos bulbos comerciais se incluem na categoria de peso inferior a $50 \mathrm{~g}$. A cultura de cebola no período intermediário, fevereiro-julho, apresenta uma situação semelhante à cultura de verão por ter uma situação adversa de tempe ratura na fase juvenil, porém não na fase de plantas adultas, resultando numa produção maior porque a bulbificação das plantas remanescentes ocorre em temperaturas amenas.

A produção é um caráter de valor comercial, dependente do somatório de inúmeras componentes que contribuem para a produtividade final. A seleção massal estratificada efetuada nos Grupos Baia do Cedo A, Baia do Cedo B, Composto Baia e Baia Triunfo, baseou-se no critério de bul bos individuais como fator seletivo primário. As avaliações em que se 
considerou o caráter peso de bulbos por unidade de área, evidenciou que a seleção massal aumentou a produtividade das populações de todos os Grupos Baia Selecionados para o cultivo de fevereiro-julho, mantendo a sequéncia hierárquica dos ciclos em todas as épocas de cultivo. Os ciclos mais avançados foram sempre os mais produtivos em todas as épocas, concordando com os resultados obtidos por MELO (1978) para os dois primeiros ciclos de seleção da Baia do Cedo e do Composto Baia.

Convém destacar que a seleção feita na cultivar Baia Triun fo para o cultivo de verão, foi a que exibiu maior produtividade na sua época específica. Torna-se evidente, pela observação dos resultados, que a seleção de verão é antagônica quando avaliada nas condições mais fa voráveis de cultivo, enquanto as seleções de fevereiro-julho mostraram ganho em todas as épocas, apenas com o inconveniente da baixa produtivida de obtida sob condições de temperaturas elevadas. Os efeitos da seleção para produtividade não são recíprocos. Aparentemente a seleção para o período intermediário se mostra mais promissora. A possível explicação para a especificidade das populações selecionadas para o verão e o seu antagonismo durante o inverno, pode estar relacionada com o fator tempera tura. A seleção de verão atua no sentido de favorecer genótipos que tenham capacidade de obter um maior desenvolvimento vegetativo e, consequen temente, produzir bulbos mais pesados sob condições de temperaturas eleva das.

A maturação fisiológica dos bulbos, condicionada pela temperatura, é um fato ainda não bem estabelecido na literatura. 0 fotoperiodismo é considerado como fator primário e a temperatura como fator se- 
cundário. Se admitirmos que as temperaturas predominantes no verão são as responsáveis pela bulbificação dos genótipos selecionados, deduz-se, que no cultivo de inverno as temperaturas prevalecentes não satisfazem às exigéncias mínimas para indução da bulbificação e as plantas permanecem ve getando, não contribuindo para a produtividade. Evidências que corroboram esta hip̄ótese são fundamentadas em observações realizadas no Vale do Submédio São Francisco, onde foram plantadas as cultivares Barreiro e Pera Norte nas três épocas de cultivo. A cultivar Barreiro é classificada como de dias curtos e maturação tardia, enquanto a Pera Norte exige fotoperí odo intermediário e tem maturação tardia. Essas cultivares, quando plantadas no período de fevereiro-julho e no inverno, não produziram bulbos normais, entretanto, sob condições de temperaturas elevadas predominantes no cultivo de verão, apresentaram uma produtividade equivalente à da Amare la Chata das Canárias.

Para um fotoperiodismo constante e ideal para o grupo de ce bolas de dias curtos, evidencia-se que as seleções de verão da cultivar Baia Triunfo, enquadram-se como as populações mais adequadas e específicas para a produção em condições de temperaturas elevadas. As populações dos Grupos Baia do Cedo A, Baia do Cedo B e Composto Baia, selecionadas para o cultivo de fevereiro-julho, mostraram-se promissoras tanto para a sua época específica como para o cultivo de inverno, equiparando-se à cultivar Amarela Chata das Canárias. Resta estabelecer se o procedimento de fazer seleções alternativas, na mesma população, nas épocas intermediária e de verão, direcionaria o comportamento quanto à produtividade das populações, obtendo-se cultivar mais versátil e com combinações gênicas que possibilitem uma maior estabilidade; ou se o intercruzanento das populações selecio 
nadas nas duas épocas conduziria a obtenção de uma cultivar adaptada ao cultivo durante todo o ano.

O número de bulbos comerciais é um importante componente da produção. Para que haja uma melhor produção é importante que esses bulbos sejam mais pesados. Por ser um caráter altamente correlacionado com a produtividade, o efeito seletivo nas populações de Baia mostrou tendências similares às observadas para o caráter produção, como podem ser verificadas, comparando-se os gráficos obtidos através das equações de, regressão. Deve-se salientar que os ciclos mais avançados mostraram tendéncia em aumentar o número de bulbos comerciais, principalmente na época mais ad versa ao cultivo de cebola. Convém notar que a seleção de bulbos individuais, notadamente bulbos de valor comercial com peso acima de $100 \mathrm{~g}$, cau sou uma resposta correlacionada em aumentar o número desses bulbos comerciais por unidade de área.

A seleção feita para época de cultivo de veräo mostrou espẹ cificidade somente para essa época, quanto ao aumento do número de bulbos comerciais. A seleção para a época intermediária foi a que exibiu maior versatilidade nas três épocas testadas.

o número de bulbos comerciais está intimamente relacionado com a sobrevivência. A sobrevivência é um caráter de valor adaptativo e diferentes cultivares de cebola apresentam comportamento diferencial quanto a essa característica. A sobrevivência não é selecionada diretamente, porém, como é um caráter adaptativo, as plantas que não sobrevivem são elí minadas na seleção de bulbos "per se", enquanto aquelas que sobrevivem e 
produzen bulbos comerciais de peso elevado são selecionadas. A época que apresentou a menor sobrevivência foi a de verão, contudo, a época intermediāria é, também, eficiente em pressionar indiretamente o caráter sobrevivência, devido à ocorrência de temperaturas elevadas durante a fase juvenil. Nessas condições, sobrevivem após o transplante somente aquelas plantas que tenfam esse caráter adaptativo. No presente trabalho obtevese uma alta sobrevivência no período intermediário. Verificando-se os dạ dos de temperatura nota-se que, excepcionalmente, ocorreram temperaturas a menas durante a fase inicial de desenvolvimento das plantas, no Experimento II. Tanto no cultivo de verão como no de fevereiro-julho, as plantas na fase juvenil, são submetidas a temperaturas elevadas, porém, na segunda época, a fase de desenvolvimento do bulbo se verifica sob condições de tem peraturas amenas, aumentando o ciclo vegetativo que contribui para um maior desenvolvimento do bulbo, corroborando as observações de GARNER e ALLARD (1923) e YAMAGUCHI et alì (1975). A seleção para sobrevivéncia mostrouse eficiente nas duas épocas. Entretanto, a época intermediária tem a vantagem de proporcionar uma seleção mais eficiente que a de verão por selecionar bulbos grandes, não afetando as qualidades de bulbo, o que pode ria ocorrer nas condições de verão onde os bulbos são menores.

Entre os grupos Baia ficou patente que a Baia do Cedo foi a que deu menor resposta à seleção, devido a população original apresentar uma grande sobrevivência em condições crîticas elevadas (DIAS et alïi, 1969). Os resultados mostram que, nas seleções futuras certa ênfase deve ser dada ao fator sobrevivência, principalmente na determinação das causas envolvidas. Postula-se que sejam várias as causas que contribuem para que certas cultivares sobrevivam mais que outras. Pode estar relacionada 
com doenças do solo provocadas por fungos dos gēneros Fusarium, Pyrenocha eta e outros; vigor da planta; bulbificação precoce que, segundo COSTA (1978), diminui substancialmente o número de plantas sobreviventes, induzindo perdas posteriores por deterioração dos bulbinhos en dorméncia; sa linidade do solo; controle da irrigação; etc. Apesar de não se saber a causa, observa-se que a sobrevivência é um caráter que responde à seleção.

A bulbificação precoce é outro caráter indesejável que reduz a potencialidade produtiva das populações de cebola. $E$ uma expressão de extrema sensibilidade à bulbificação quando ocorrem condições excessivas de fotoperíodo e temperatura na fase juvenil pré e pós-transplan te. Nas condições de verão de Piracicaba, as cultivares com período idêntico de maturação, comportaram-se diferencialmente quanto ao fenómeno de bulbificação precoce na fase juvenil (COSTA, 1978). Nas condições do Vale do Submédio São Francisco, ao contrário do que ocorre em Piraci caba, o fotoperiodismo não é tão crítico, situando-se em torno de 12:00 horas com variação desprezível, tudo fazendo acreditar que a temperatura seja o fator crítico. No cultivo de inverno a bulbificação precoce praticamente não se manifesta. Contudo, no cultivo de verão ocorre uma mai or tendéncia, em relação às outras épocas de cultivo, possivelmente relacionada com o fator temperatura. HEATH (1945) constatou que ao iniciar a bulbificação sob condições de temperaturas elevadas, cessa abruptamente a emissão de novas folhas. Além dos fatores fotoperíodo e temperatura é conhecido que o nitrogénio quando aplicado em doses elevadas, retarda a bulbificação e a maturação de bulbos de cebola, ocasionando um maior período vegetativo. Nos trés experimentos usou-se doses e épocas de aplicação padronizadas para adubação. Propõe-se a realização de ensaỉos 
com doses e épocas de aplicação de Nitrogénio sob as condições de verão do Submédio São Francisco, procurando-sè uma solução ambiental a curto prazo para o aumento da produtividade das cultivares.

Os bulbinhos precoces são eliminados na seleção por não atingirem os critéríos seletivos, consequentemente, a seleção de verão foi a mais eficiente em excluir genótipos com eșta característica. A seleção na época intermediária é de menor eficiência, em virtude de ocorrer muitos escapes. Tanto assim que a seleção na época intermediária ainda apresentou uma grande quantidade de bulbinhos precoces no cultivo de inverno.

A ocorrénicia de plantas improdutivas é outra manifestação indesejável no comportamento de cultivares de cebola. As plantas improdu tivas são as remanescentes que conseguiram sobreviver, porém, não bulbificaram, contribuindo para a redução da produtividade. As causas da ocorrência de plantas improdutivas não estão bem estabelecidas. Presume-se que estejam relacionadas com a maturidade. Supõe ABDALLA (1967) que a contínua emergéncia de folhas, com ou sem início de bulbificação, resultam em plantas improdutivas, interferindo na maturidade. Sabe-se, entretanto, que além da componente genética, várias causas de natureza ambiental estão envolvidas. Possíveis causas podem estar relacionadas com doenças do solo como raiz rosada causada por Pyrenochaeta terrestris (Hansen), Gorens, Walker e Larson, que em condições de temperaturas elevadas eliminam as plantas, porém, sob condições de temperaturas amenas não chegam a ma tar, mas alteram o seu comportamento. Outras causas que também podem estar envolvidas, além da ocorrência de doenças, são o suprimento de nitrogê nio e as exigências mínimas de temperatura para a bulbificação. Tudo pa- 
rece indicar que o caráter tem muitas componentes ambientais (BUSO, 1978). Por esse motivo, talvez, a seleção para plantas improdutivas não tenha apresentado. resposta definida.

A razão do antagonismo das populações do Grupo Baia Triunfo selecionadas para o cultivo de verão, quando cultivadas no inverno, devese exclusivamente à maior incidência de plantas improditivas. Este fato evidencia a exigéncia da maturação fisiológica em função da temperatura e não do fotoperiódismo. Para comprovar essa hipótese, sugere-se que a seleção na époća intermediária seja feìta a partir de plantas com maturação tardia e, posteriormente, testá-las nas outras épocas. A avaliação de plantas improdutivas é feita quando mais de $70 \%$ das populações estão no ponto de colheita comercial. As plantas que ainda não formaram bulbos podem posteriormente bulbificar, sendo uma questão de uniformidade do materíal. Esta evidência é suportada na observação de cultivares híbridos bem adaptados a uma região que normalmente produzem uma quantidade insignificante de plantas improdutivas. A cultivar Amarela Chata das Canárias, apesar de bem adaptada ao cultivo no vale do Submédio São Francisco, produz uma quantidade razoável de plantas improdutivas, refletindo a existência de variabilidade para esta característica.

O ideotipo de uma cultivar de cebola para as condições do Vale do Submédio São Francisco, envolve atributos individuais discutidos anteriormente. Assim é que, uma cultivar ideal seria aquela que numa população inicial de 500.000 plantas por hectare, tivesse no final do ciclo $100 \%$ de sobrevivência, $100 \%$ de bulbos comerciais, cada bulbo pesando 100 gramas, o que daria uma produtividade de 50 t/ha, zero\% de plantas improdu 
tivas, zero\% de bulbinhos precoces e zero\% de plantas com escapo floral. O conjunto dessas características reunidas através de um índice constituise no mérito varietal. A cultivar ideal obteria o valor 3,0 para o mérito varietal. Teoricamente,. o mérito varietal tem um valor mínimo de $-1,0$ e um ideal de 3,0, podendo ultrapassar o valor 3,0 desde que se abtivesse um valor ideal para todas as características desejáveis e o peso médio dos bulbos ultrapassasse $100 \mathrm{~g}$. E um critério arbitrário, mas que pode. dar uma ponderação do conjunto de caracteres vantajosos e desvantajosos, a fim de estabelecer uma comparação entre as populações. Só serve para julgamento em termos comparativos. Como era de se esperar, após a observação individual das características apresentadas, o mérito varietal das populações testadas apresentou os maiores valores no cultivo de inverno, época mais favorável, e os menores valores no cultivo de verão.

0 mérito varietal mostrou-se eficiente em confirmar que a seleção no Grupo Baia Triunfo para as condições de verão foi eficiente, ten do o segundo ciclo de seleção obtido o melhor índice na época para a qual foi selecionado e de maneira superior ao da cultivar padrão, Amarela Chata das Canárias. As populações selecionadas no cultivo de verão mostraram especificidade para o cultivo sob condições de temperaturas elevadas. Sem dúvida, o caráter plantas improdutivas foi o que mais interferiu na potencialidade produtiva das seleções de verão, no cultivo de inverno. 0 mérí to varietal dos ciclos mais avançados de seleção dos grupos selecionados para o cultivo fevereiro-julho, apresentaram valores elevados tanto no cul tivo de fevereiro-julho como no de inverno, mostrando uma boa adaptação às duas épocas de cultivo. 
A seleção de populaçães de cebola do Grupo Baia Periforme, envolvendo épocas de cultivo com peculiaridades climáticas contrastantes, evidenciaram resultados aparentemente de natureza específica. 0 melhoramento de cebola nas condiçães do Vale do Submédio São Francisco mostra que o fator temperatura é, antes de tudo, um fator primário e crítico na adaptação de uma cultivar. Torna-se difícil ter uma cultivar para o plantio em.todas as épocas do ano. Os resultados mostram que inicialmente devese aproveitar as populações selecionadas para épocas específicas e, posteriormente, tentar obter um material mais estável que possa apresentar um comportamento consistente em todas as épocas de cultivo.

- Vale do Submédio São Francisco é a região brasileira que apresenta maior potencialidade para a produção de cebola, a níveis econômi cos durante todo o ano, pois, o fator limitante é a temperatura e não o fotoperíodo. Existem possibilidades, através do melhoramento genético, de se obter cultivares capazes de apresentar boa produtividade em todas as épocas de cultivo, podendo regularizar o difícil abastecimento do mercado brasileiro quando se fizer necessário. 


\section{CONCLUSÖES}

1. Populações de cebola mostraram comportamento diferencial quanto à época de cultivo, definida pelo fator temperatura, no Vale do Sub médio São Francisco.

2. O melhoramento de cebola em função da época de cultivo, no vale do Submédio São Francisco, mostrou ser de natureza específica, evi denciado quando as populações selecionadas em épocas diferentes foram testadas de maneira recíproca.

3. A seleção para condições de temperaturas elevadas, reali zada na Baia Triunfo, foi a mais promissora para o cultivo de verão, inclu sive obtendo um mérito varietal superior ao da cultivar Amarela Chata das Canārias. Entretanto, no cultivo de inverno, apresentou um mérito varietal inferior ao de todas as populações testadas, excetuando-se a Composto Baia Original.

4. A seleção para o cultivo de fevereiro-julho apresentouse eficiente em todas as épocas, mostrando-se mais adequada para a sua 
epoca e para o cultivo de inverno.

5. o mérito varietal, obtido através de todos os caracteres avaliados, mostrou que a utilização de um índice empírico facilita a carac terização do comportamento de populações de cebola.

6. A principal alteração ocorrida na seleção de verão, quan do cultivada no inverno, foi o aumento do número de plantas improdutivas, contribuindo para o decréscimo da produção e do mérito varietal.

7. Os ganhos obtidos através da seleção massal estratificada, em todas as características avaliadas, foram mais evidentes e consis tentes quando estimados no cultivo de verão.

8. Temperatura é fator primário no comportamento diferencial de cultivares de cebola de dias curtos, na região tropical do Vale do Submédio São Francisco, onde fotoperiodismo é constante e ideal para as cultivares de dias curtos. 
8. SUMMARY

\section{SELECTION OF ONION POPULATIONS (Allium cepa L.) FROM BAIA PERIFORME GROUP, FOR SEASON PLANTING IN THE SUB-MEDIUM SATO FRANCISCO YALLEY}

Onion cultivars of Baia Periforme group showed the most promissing for growing at the Sub-Medium São Fracisco Valley located at latitude $8^{\circ}$ to $9^{\circ}$ South, where the day lenght is constant and about 12 hours. The aim of this research was to check the efficiency of onion populations selection for specific season of planting as well the reciprocal effects of selection in others ones.

The onion breeding of Baia Periforme group for the conditions of Sub-Medium São Francisco Valley was based on the stratrified mass selection, in two crop season by the selection criteria of individual bulbs with over 100 grams weight. Original populations of Baia do Cedo and Composto Baia, were selected at the season february to july and Baia Triunfo in the summer crop. It proceeded from two to three cycle of selection. 
There were conducted three trials in the random block design, in three planting season, defined by the temperature factor: summer crop (october to march); february to july crop and winter crop. (april to september). The progress attained by selection was estimated by linear regression coeficient and variance analyses. The control was the cultivar Amarela Chata das Canárias, which showed well known performance in this region. The evaluated characters were yeld (ton/ha), survival, commercial bulbs, unproductive plants and early onion sets. All characters were weighted by index named varietal merit.

The selection for higher temperature season made in the Baia Triunfo, showed to be the most promissing and specific concerning to the summer crop. However showed poor performance in the winter crop, where there was marked increase of unproductive plant number. The selected populations for february to july season showed gains in all seasons. The highest gains were specific for february to july season as well for winter crop.

The population- selection in contrasting seasons, became viable the onion crop, all year round in the tropics where the temperature showed to be the determinant and primary factor in the onion short day varietal performance. 


\section{LITERATURA CITADA}

ABDALLA, A.A., 1967. Effect of temperature and photoperiod on bulbing of the common onion (Allium cepa L.l under arid tropical conditions of the Sudan. Experimental Agriculture. London, 03: 137-142.

BAKER, R.S. e G.E. WILCOX, 1961. Effect of foliage damage and stand reduction on onion yield. Proceedings of the American Society for Horticultural Science. Beltsville, 78: 400-405.

BUSO, J.A., 1978. Estimativas de parámetros genéticos de caracteres de planta e bulbo de cebola (Allium cepa L.). Piracicaba, ESALQ/USP, 132p. (Dissertação de Mestrado).

COSTA, C.P., 1978. Melhoramento de cebola (Allium cepa L.) de dias curtos para sistemas de cultivo. Piracicaba, ESALQ/USP, 138p. (Tese de Livre-Docência).

DIAS, M., 1963. Instruções para a cultura da cebola pelo processo de bul 
binho. Parte I. Produção de bulbinho. Piracicaba, Instituto de Genética/ESALQ/USP. 8p. (mimeografado).

DIAS, M.; R. VENCOVSKY e C.P. da COSTA, 1964. Eficiência da seleção mas sal contra perfilhamento do bulbo de cebola: In: $V$ Reunião Anual da Sociedade de Olericultura do Brasil, Recife. 6p. (mimeografado).

DIAS, M. e C.P. da COSTA, 1967. Eficiência de um ciclo de seleção massal contra florescimento prematuro na variedade de cebola Barreiro (Allium cepa L.). Piracicaba, Relatório Científico do Instituto de Genética/ESALQ/USP, p. 81-83.

DIAS, M.; C.P. da COSTA e R. VENCOVSKY, 1969. Seleção para a cultura "do cedo" na variedade brasileira de cebola Baia Periforme Precoce (Allium cepa L.). In: IX Reunião Anual da Sociedade de Olericultura do Brasil, 5p. (mimeografado).

DIAS, M., 1970. Transferência de genes de variedades de dia curto em ce bola (Allium cepa L.). Piracicaba, Relatório Cientîfico do Instituto de Genética/ESALQ/USP, p. 46.

DIAS, M. e C.P. da COSTA, 1970. Programa de melhoramento da , cebola (Allium cepa L.) em andamento no setor de melhoramento de hortaliças do Instituto de Genética/ESALQ/USP. Piracicaba. 6p. (mimeografado).

FALCONER, D.S., 1960. Introduction to quantitative genetics. London, Oliver-Boyd. $\quad 385 p$. 
GARDE, A. e N. CARDE, 1977. Culturas horticalas. 4a. ed., Lisboa, Livraria Clássica Editora. $\quad 449 p$.

GARNER, W.W. e H.A. ALLARD, 1920. Effect of relative length of day and night and other factors of the environment on growth and reproduction in plantas. Jourmal of Agricultural Research. Washington, 18: $553-606$.

GARNER, W.W. e H.A. ALLARD, 1923. Further studies in photoperiodism, the response of the plant to relative length of day and night. Joumal of Agricultural Research. Washington, 23: 871-920.

HEATH, O.V.S., 1943. Studies in the physiology of the onion plant. I. An investigation of factors concerned in the flowering (bolting) of onions grown from sets and its prevention. Part 2. Effects of day length and temperature on onions grown from sets, and general discussion. Annals Applied Biology. London, 30: 308-319.

HEATH, O.V.S., 1945. Formative effects of environmental factors as exemplified in the development of the onion plant. Nature. London, 155: $623-626$.

JONES, H.A. e L.K. MANN, 1963. Onions and their alzies. London, Leonard Hill Books = 286p.

KUCKUCK, H. e G. KOBABE, 1959. küchenzwiebel, Allium cepa L. In: 
Kappert, H. e W. Rudorf, ed. Fiandbuch der pflanzenzüchtiong. 2a. ed. Berlin, Paul Parey. Vol. VI p. 270-312.

LONNQUIST, J.H., 1960. El mejoramiento de las poblaciones de maiz. Programa Cooperativo Centroamericano para el Mejoramiento del Maiz. Manágua, 6: 14-22.

MAGRUDER, R. e H.A. ALLARD, 1937. Bulb formation in some American and European varietties of onions as affected by length of day. Joumal of Agricultural Research. Washington, 54: 719-752.

MELO, P.C.T., 1978. Seleção massal estratificada em duas populações de cebola (Allium cepa L.) Baia Periforme no Vale do Submédio São Francisco. Piracicaba, ESALQ/USP, 72p. (Dissertação de Mestra dol.

PIMENTEL GOMES, F., 1970. Curso de Estatistica Expemimental. São Pau1o, Livraria Nobel. 430p.

STEEL, R.G.D. e J.H. TORRIE, 1960. Principles and Procedures of Statistics, with Special Reference to the Biological Sciences. New York, McGraw Hill. 481p.

THOMPSON, H.C. e O. SMITH, 1938. Seedstalk and bulb development in the onion, Allium cepa L.. Bulletin of Comell Agricultural Experiment Station. Geneva, $n^{8} 708,21 p$. 
TORRES, C.G., 1951. A influência do fotoperíodo na formação do bulbo nas variedades Riograndenses de cebola (Allium cepa L.). Agros. Pelotas, $04: 219-234$.

VAVILOV, N.I., 1951. The origin, variation, immunity and breeding of cultivated plants. Chronica Botonica. Waltham, 13: 1-364.

WALKER, J.C. e L.R. JONES, 1921. Relation of soil temperature and other factors to onion smut infection. Joumal of Agricultural Research. Washington, $22: 235-262$.

WANDERLEY, L.J.G., D. MENEZES, J.A. CANDEIA e V.A.L. SA, 1978. Estudo de cultivares de cebola (Allium cepa L.) para o verão do Submédio São Francisco. In: XVIII Congresso da Sociedade de Olericultura do Brasil, Mossoró. 3p. (mimeografado).

YAMAGUCHI, M., K.N. PAULSON, M.N. KINSELLA e R.A. BERNHARD, 1975. Effects of soil temperature on growth and quality of onion bulbs (Allium cepa L.J used for dehydration. Journal of the American Society for Horticultural Science. Mount Vernon, 100: 415-419.

ZINSLY, J.R., 1968. Estudo sobre a seleção massal em milho (Zea mays L.). Piracicaba, ESALQ/USP, 60p. (Tese de Mestrado). 
10. APENDICE

10.1. Tabelas 
Tabela 01 - Valores e significāncias dos quadrados médios para o mérito varie tal e cinco caracteres de cebola avaliados no cultivo de verão. Experimento I. Belém do Säo Francisco, PE., $1977 / 78$.

\begin{tabular}{|c|c|c|c|c|c|c|c|}
\hline & & & & Quadrados Mëd & dos Car & acteres & \\
\hline Fontes de Variação & G.L. & $\begin{array}{l}\text { Mérito } \\
\text { Varietal }\end{array}$ & Produção & Sobrevivēncia & $\begin{array}{c}\text { Bulbos } \\
\text { Comerciais }\end{array}$ & $\begin{array}{c}\text { Plantas } \\
\text { Improdutivas }\end{array}$ & $\begin{array}{l}\text { Bulbintios } \\
\text { Precoces }\end{array}$ \\
\hline Repet 1çōes & 5 & $0,13^{\star \star}$ & $76,59 * \star$ & $1,34^{\star}$ & $2.05 \mathrm{~ns}$ & $1.92 \star$ & $1,37 \mathrm{~ns}$ \\
\hline Tratamentos (Populaçōes) & 11 & $0.76^{\star \star}$ & $99.84^{\star \star}$ & $6.45^{\star \star}$ & $22.10^{\star \star}$ & $3.05^{* 1}$ & $10,62^{\star \star}$ \\
\hline Entra Grupos & 4 & $0.23^{\star \star}$ & $39,03^{\star \star}$ & $2,66^{\star \star}$ & $6,23^{\star \star}$ & $3,58^{\star \star}$ & $8,89^{\star \star *}$ \\
\hline Entra Grupos Baia & 3 & $0.24^{\star \star}$ & $31.11^{\star}$ & $3.48^{\star \star}$ & $6.88^{\star \star}$ & $3,96^{\star \star}$ & $6,19^{\star \star}$ \\
\hline Test. vs. Grupos Bala & 1 & $0,18^{\star}$ & $62.69^{\star \star}$ & $0.22 \mathrm{~ns}$ & $4,27^{\star}$ & $2.44 \mathrm{~ns}$ & $17.01^{\star \star}$ \\
\hline C1clos $B C_{B}$ & 1 & $1,20 \star \star$ & $126,10^{\star \star}$ & $21,76^{\star \star}$ & $35,50^{\star \star}$ & $0.09 \mathrm{~ns}$ & $0,01 \mathrm{~ns}$ \\
\hline Ciclos $B C_{A}$ & 2 & $0.6 e^{\star \star}$ & $85,40^{\star \star}$ & $2.50 \star$ & $18,09^{\star \star}$ & $0,56 \mathrm{~ns}$ & $12,37^{\star \star}$ \\
\hline Regressào linear/BC $C_{A}$ & 1 & $1.36^{\star \star}$ & $170,25^{\star \star}$ & $4.07 \star \star$ & $35,74^{\star \star}$ & $0.74 \mathrm{~ns}$ & $23,58^{\star \star}$ \\
\hline Regressào quadrātıca/BC $A$ & 1 & $0.01 \mathrm{~ns}$ & $0.54 \mathrm{~ns}$ & $0.93 \mathrm{~ns}$ & $0.44 \mathrm{~ns}$ & $0,38 \mathrm{~ns}$ & $1.17 \mathrm{~ns}$ \\
\hline C1clos CB & 2 & $1,11^{\star \star}$ & $130.82^{\star \star}$ & $11,34^{\star \star}$ & $39,54^{\star \star}$ & $1.60 \mathrm{~ns}$ & $5,40^{* *}$ \\
\hline Regressào linear/CB & 1 & $1.65^{\star \star}$ & $173,28^{\star \star}$ & $20,15^{\star \rightarrow}$ & $60,03^{\star \star}$ & $0.01 \mathrm{~ns}$ & $1.88 \mathrm{~ns}$ \\
\hline Regressào quadrátıca/CB & 1 & $0.56^{\star \star}$ & $88,38^{\star \star}$ & $2,52^{\star}$ & $19.04^{\star \star \star}$ & $3.17 \mathrm{~ns}$ & $8.91^{\text {\#* }}$ \\
\hline C1clos BT & 2 & $1.39^{\star}$ & $191.80^{\star \star}$ & $5.42^{\star \star}$ & $33,71^{\star \star}$ & $7.43^{\star \star}$ & $22,83^{\star \star}$ \\
\hline Regressào IInear/BT & 1 & $2,75^{\star \star *}$ & $380,81 \star \star$ & $10,58^{\star \star}$ & $65,75^{\star \star}$ & $4.90^{*}$ & $42,94^{* *}$ \\
\hline Regressào quajrätica/BT & 1 & 0,03 ns & $2,70 \mathrm{~ns}$ & $0.25 \mathrm{~ns}$ & $1,66 \mathrm{~ns}$ & $9.91^{\star \star}$ & $2.73 \mathrm{~ns}$ \\
\hline Resíduo & 55 & 0,03 & 7.94 & 0,43 & 0,99 & 0,79 & 0.90 \\
\hline Mēdia Geral & & 1,12 & 11,52 & 14,83 & 11,39 & 3,72 & 8,36 \\
\hline Coeficiente de Variação & & 15,46 & 24,48 & 4,45 & 8,69 & 23,92 & 11,36 \\
\hline Unidade & & & t/ha & $\begin{array}{l}\text { W } \\
\text { We de } \\
\text { plantas }\end{array}$ & $\begin{array}{c}\sqrt{x} \\
x: \text { ne de } \\
\text { bulbos }\end{array}$ & $\begin{array}{c}\sqrt{y} \\
\text { Y: ne de } \\
\text { plantas }\end{array}$ & $\begin{array}{c}\sqrt{2} \\
2: n 8 \text { de } \\
\text { bulbinhos }\end{array}$ \\
\hline
\end{tabular}

ns: não significativo; *: significativo a $5 \%$ **: significativo a $1 \%$ de probabilidade

Erupos: Testemuntia (Canérias); Bala do [edo B [SMJ-I e SMJ-II); Baia do Cedo A (SM)-I, SM]-II e SMJ-III), Composto Bata (SMJ-I. SMJ-II e SMJ-III) e Bala friunfo (SMJ-0, SMJ-I e SMJ-II). 
Tabela 02 - Valores e significāncias dos quadrados médios para o mérito varie tal e cinco caracteres de cebola avaliados no cultivo de fevereiro-julho. Experimento II. Belém do São Francisco, PE., 1978.

\begin{tabular}{|c|c|c|c|c|c|c|c|}
\hline & & & & Quadrados Médios & Carac & & \\
\hline Fontes de variação & G.L. & $\begin{array}{l}\text { Mérito } \\
\text { Varietal }\end{array}$ & Produçāo: & Sobrevi vēncia & $\begin{array}{c}\text { Bulbos } \\
\text { Comerciais }\end{array}$ & $\begin{array}{c}\text { Plantas } \\
\text { Imp dutivas }\end{array}$ & $\begin{array}{l}\text { Bulbinhos } \\
\text { Precoces }\end{array}$ \\
\hline Repet1çōes & 5 & $0,49^{\star \star}$ & $235.14^{\star \star}$ & $1,95^{\star}$ & $5,55^{\star \star}$ & $9,47^{\star \star}$ & $1.58^{\star}$ \\
\hline Tratamentos (Populaçōes) & 1.1 & $0,30^{\star *}$ & $70.54 \mathrm{~ns}$ & $4.47 * *$ & $5,92^{\star \star}$ & $6,96 *$ & $3.25^{* *}$ \\
\hline Entre Grupos & 4 & $0.47 \star \star$ & $105,42 \mathrm{~ns}$ & $8,59^{\star \star}$ & $8.77 * \star$ & $3,47 \mathrm{~ns}$ & $1.70^{\star}$ \\
\hline Entre Grupos Bala & 3 & $0,38 \mathrm{~ns}$ & $121.11 \mathrm{~ns}$ & $5,85^{\star \star}$ & $6.12^{\star}$ & $2,99 \mathrm{~ns}$ & $1,43 \mathrm{~ns}$ \\
\hline Test. vs. Grupos Ba1a & 1 & $0,73^{\star}$ & $58.36 \mathrm{~ns}$ & $16,80^{\star \star}$ & $16,73^{\star \star}$ & $4.93 \mathrm{~ns}$ & $2,50^{*}$ \\
\hline$C 1 \operatorname{clos} B C_{B}$ & 1 & $0,00 \mathrm{~ns}$ & $6,60 \mathrm{~ns}$ & $0,01 \mathrm{~ns}$ & $0,01 \mathrm{~ns}$ & $0,42 \mathrm{~ns}$ & $0,07 \mathrm{~ns}$ \\
\hline$C \perp c \cos B C_{A}$ & 2 & $0,45^{\star}$ & $120,32 \mathrm{~ns}$ & $2,91^{\star}$ & $6,26^{\star}$ & $5.73^{\star}$ & $2.51^{\star \star}$ \\
\hline Regressào linear/BC $C_{A}$ & 1 & $0.72^{\star}$ & $234,97^{\star}$ & $2.97^{\star}$ & $8,69^{\star}$ & $10,43^{\star}$ & $4,95^{\star \star}$ \\
\hline Regressāo quadrät1ca/BC $C_{A}$ & 1 & $0,18 \mathrm{~ns}$ & $5,68 \mathrm{~ns}$ & $2,86^{\star}$ & $3,83 \mathrm{~ns}$ & $1,02 \mathrm{~ns}$ & $0,07 \mathrm{~ns}$ \\
\hline Ciclos & 2 & $0.12 \mathrm{~ns}$ & $48.84 \mathrm{~ns}$ & $0,29 \mathrm{~ns}$ & $2,24 \mathrm{~ns}$ & $15,14^{\star \star}$ & $9,80^{\star \star}$ \\
\hline Regressào línear/CB & 1 & $0,00 \mathrm{~ns}$ & $20,54 \mathrm{~ns}$ & $0,42 \mathrm{~ns}$ & $0,72 \mathrm{~ns}$ & $2,51 \mathrm{~ns}$ & $15,94^{\star \star}$ \\
\hline Regressäo quadrát1ca/CB & 1 & $0.25 \mathrm{~ns}$ & $77.15 \mathrm{~ns}$ & $0.17 \mathrm{~ns}$ & $3,77 \mathrm{~ns}$ & $27.76^{\star \star}$ & $3,85^{\star}$ \\
\hline C1clos BT & 2 & $0.17 \mathrm{~ns}$ & $4,63 \mathrm{~ns}$ & $4,22^{\star \star}$ & $6.47^{\star}$ & $10,26^{\star \star}$ & $2,02^{\star}$ \\
\hline Regressado Hnear/bl & 1 & $0,33 n:$ & $0.85 \mathrm{~ns}$ & $3.71^{\star \star *}$ & $92.90^{\star \star}$ & $9,90^{\star}$ & $3.72^{\star}$ \\
\hline Regressào quadrät1 ca/BT & 1 & $0.01 \mathrm{~ns}$ & $8,41 \mathrm{~ns}$ & $2.73^{\star}$ & $0,05 \mathrm{~ns}$ & $10,63^{\star}$ & $0.32 \mathrm{~ns}$ \\
\hline Resfouo & 55 & 0,11 & 52.48 & 0.62 & 1.49 & 1,76 & 0.59 \\
\hline Média Geral & & 3,78 & 28,28 & 15,01 & 13,40 & 6,23 & 44,51 \\
\hline Coeficiente de Variaçāo & & 18,63 & 25,60 & 5,26 & 9,10 & 21,35 & 1,73 \\
\hline Unidade & & & t/ha & $\begin{array}{c}\sqrt{W} \\
\text { W: no de } \\
\text { plantas }\end{array}$ & $\begin{array}{c}\sqrt{x} \\
x: \text { no de } \\
\text { bulbos }\end{array}$ & $\begin{array}{c}\sqrt{y} \\
\text { Y: no de } \\
\text { plantas }\end{array}$ & $\begin{array}{l}\sqrt{2+0,5} \\
2: \text { no de } \\
\text { buibinnos }\end{array}$ \\
\hline
\end{tabular}

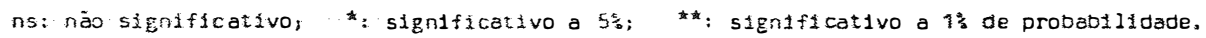

Grupos: Testemunha (Canárlas); Bala do Cedo B (SMJ-I e SMJ-II); Bala do Cedo A (SMJ-I, SMJ-II e SMJ-III), Composto Ba1a (SMJ-I, SMJ-II e SMJ-III) e Baja Triunfo (SMJ-0, SMJ-I e SMJ-II). 
Tabela 03 - Valores e significáncias dos quadrados médios para o mérito varie tal e cinco caracteres de cebola avaliados no cultivo de inverno. Experimento III. Belēm do São Francisco, PE., 1979.

\begin{tabular}{|c|c|c|c|c|c|c|c|}
\hline Fontes de Variaçāo & G.L. & $\begin{array}{l}\text { Mērito } \\
\text { Varietal }\end{array}$ & Produçāo & Sobrevivēncia & $\begin{array}{l}\text { Bulbos } \\
\text { Comerciais }\end{array}$ & $\begin{array}{c}\text { Plantas } \\
\text { Improdutivas }\end{array}$ & $\begin{array}{l}\text { Bulbinhos } \\
\text { Precoces }\end{array}$ \\
\hline Repet1çöes & 05 & $0,59 \star \star$ & $272.19^{\star \star}$ & $0,43 \mathrm{~ns}$ & $6.86^{\star \star}$ & $30,43^{\star \star}$ & $4.11 * *$ \\
\hline $\begin{array}{l}\text { Tratamentos } \\
\text { (populaçóes) }\end{array}$ & 08 & $0.73^{\star \star}$ & $346,88^{\star \star}$ & $1,20 \star \star$ & $30,55^{\star \star}$ & $38,57 \star \star$ & $19.09 * \star$ \\
\hline Resluno & 40 & 0,07 & 38,81 & 0,32 & 0,85 & 1,38 & 0,77 \\
\hline Mēdia Geral & & 1,87 & 30,27 & 16,37 & 13,67 & 7,43 & 3,78 \\
\hline \multicolumn{2}{|c|}{ Coeficierite de Variaçāo } & 13,90 & 20,58 & 3,42 & 6,73 & 15,75 & 23,28 \\
\hline Untdade & & & t/ha & $\begin{array}{l}\sqrt{w} \\
\text { W: nQ de } \\
\text { plantas }\end{array}$ & $\begin{array}{c}\sqrt{x} \\
x \text { ng de } \\
\text { bulbos }\end{array}$ & $\begin{array}{l}\sqrt{1+0,5} \\
Y: \text { no de } \\
\text { plantas }\end{array}$ & $\begin{array}{l}\sqrt{2+0,5} \\
z: \text { ne de } \\
\text { buibinhos }\end{array}$ \\
\hline
\end{tabular}

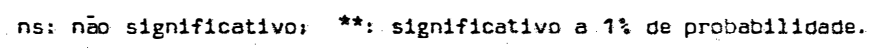


Tabela 04 - Valores médios do mérito varietal, produção, sobrevivēncia, bulbos comerciais, plantas improdutivas e butbinhos precoces. Cultivo de verāo. Experimento I. Betém do São.: Francisco, PE., $1977 / 78$.

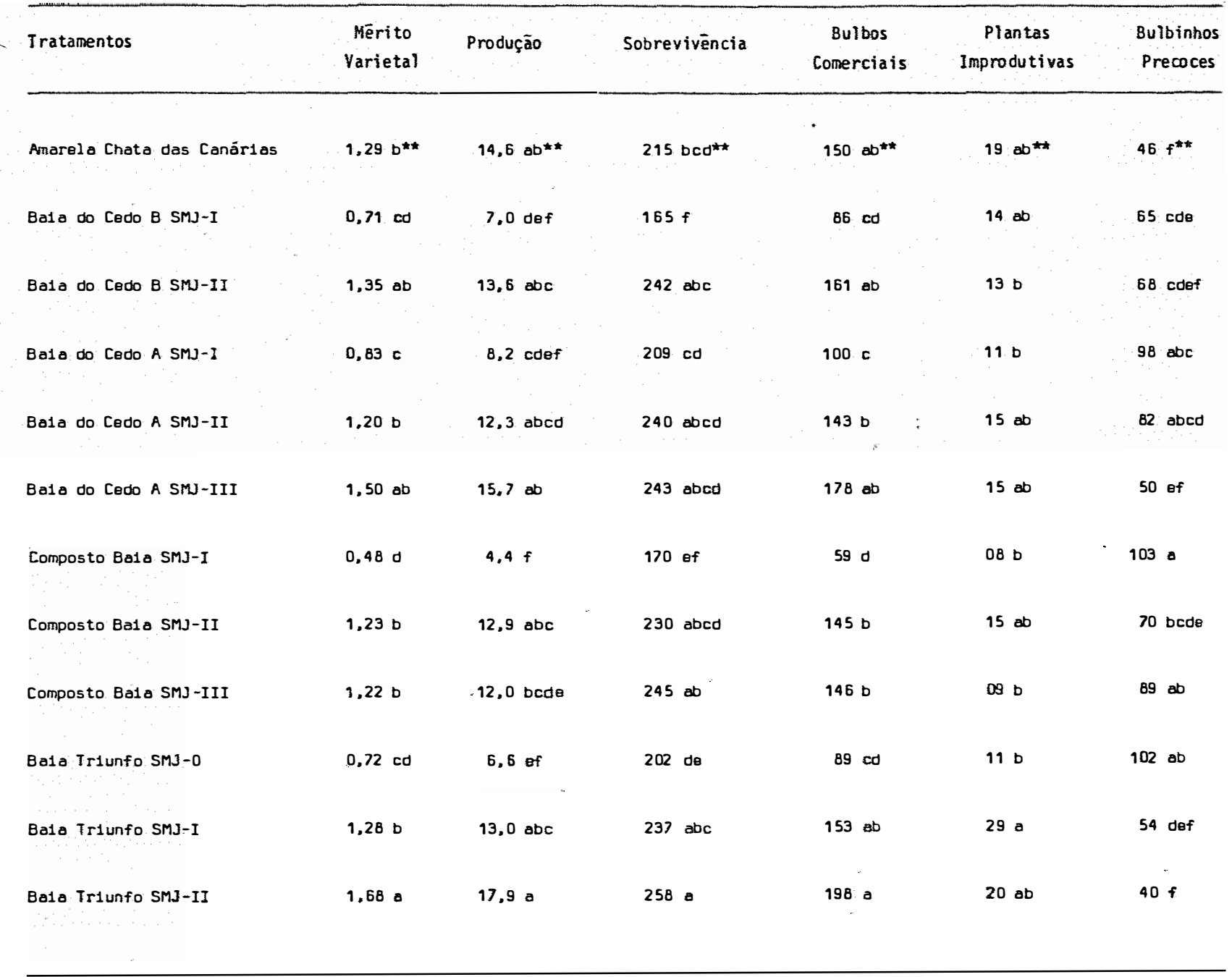

*: Dados obtidos numa parcela de $6,0 \mathrm{~m}^{2}$ com lotaçào 1nicial de 300 plantas.

Experimento an blocos casualizados com 6 repet1çöes.

**: Médias dentra da coluna seguidas da mesma letra nào diferem significativamente pelo teste de Tukey, ao nivel de 5: de proballidade. 
Tabela 05 - Valores médios do mērito varietal, produção, sobrevivēncia, bulbos comerciais, plantas improdutivas e bulbinhos precoces. Culti vo de fevereiro-julho. Experimento II. Belēm do São FrancisCO, PE., 1978.

\begin{tabular}{|c|c|c|c|c|c|c|}
\hline Tratamentos & $\begin{array}{l}\text { Mérito } \\
\text { Varietal }\end{array}$ & Produçāo & Sobrevivēncia & $\begin{array}{l}\text { Bulbos } \\
\text { Comerciais }\end{array}$ & $\begin{array}{c}\text { Plantas } \\
\text { Improdutivas }\end{array}$ & $\begin{array}{l}\text { Bulbinhos } \\
\text { Precoces }\end{array}$ \\
\hline Amarela Chata das Canárias & $2,11 a b^{\star \star}$ & $31,3: a^{\star \star}$ & $283 a^{\star \star}$ & $226 a b^{\star \star}$ & $52 a b^{\star \star}$ & $06 a b^{\star *}$ \\
\hline Ba1a do Cedo 8 SMJ-I & $1.79 \mathrm{abc}$ & $27.0 \mathrm{a}$ & 224. bc & $176 a b c$ & $45 a b c$ & $03 \mathrm{~b}$ \\
\hline Bala do Cedo B SMJ-II & $1.75 \mathrm{abc}$ & 28.5 a & $223 \mathrm{bc}$ & $176 a b c$ & $43 a b c$ & $04 \mathrm{~b}$ \\
\hline Bala do [edo A SMJ-I & $2.26 \mathrm{a}$ & $36,5 . a$ & 258 ab & $229 a$ & $23 \mathrm{bc}$ & 06 ab \\
\hline Bala do Cedo A SMJ-II & 1,80 abc & 30,9 a & $217 \mathrm{bc}$ & $177 \mathrm{abc}$ & $38 a b c$ & 020 \\
\hline Bala do Cedo A SMJ-III & $1,77 \mathrm{abc}$ & $27.7 \mathrm{a}$ & $228 \cdot a b c$ & $182 \mathrm{abc}$ & $45 \mathrm{abc}$ & $01 \mathrm{~b}$ \\
\hline Composto Ba1a SMJ-I & $1.83 \mathrm{abc}$ & 26,2 a & 236 $a b c$ & 195 ab & $29 \mathrm{bc}$ & 120 \\
\hline Composto Ba1 a SMJ-II & $1.56 \mathrm{bc}$ & 23.2 a & $237 a b c$ & $164 \mathrm{bc}$ & 72 a & $01 \mathrm{~b}$ \\
\hline Composto Ba1a SMJ-III & $1,80.00 \mathrm{c}$ & 28.9 a & $225 \mathrm{bc}$ & $182 \mathrm{abc}$ & $42 a b c$ & 010 \\
\hline Baía Trlunfo SMJ-O & $1.73 a b c$ & $25.6 \cdot a$ & $210 \mathrm{co}$ & $193 \mathrm{abc}$ & $21 \mathrm{c}$ & 05 ob \\
\hline Bala Triunfo SMJ-I & $1.63 \mathrm{abc}$ & $27.4 \mathrm{a}$ & $214 \mathrm{bcd}$ & $162 \mathrm{bc}$ & $51 \mathrm{abc}$ & $01 \mathrm{~b}$ \\
\hline Bala Triunfo SMJ-II & $1,40 \mathrm{c}$ & 26,2 a & 1720 & $132 \mathrm{c}$ & $40 a b c$ & 000 \\
\hline
\end{tabular}

*: Dados odtidos nuna parcela de $6,0 \mathrm{~m}^{2}$ com lotaçào $1 \mathrm{n} 1 \mathrm{clal}$ de 300 plantas. Experimento en blocos casualizados cam E repet1çōes.

*: Médlas dentro da coluna seguldas da mesma letra näo diferem slgniflcativamente pelo test de Tukey. ao nivel de $5 \%$ oe probabllidade. 
Tabela 06 - Valores médios do mérito varietal, produção, sobrevivēncia, bulbos comerciais, plantas improdutivas e bulbinhos precoces. Culti vo de inverno. Experimento III. Belēm do São Francisco, PE., 1979.

\begin{tabular}{|c|c|c|c|c|c|c|}
\hline Tratamentos & $\begin{array}{l}\text { Mérito } \\
\text { Varietal }\end{array}$ & Produçāo & Sobrevivēncia & $\begin{array}{l}\text { Bulbos } \\
\text { Comercials }\end{array}$ & $\begin{array}{c}\text { Plantas } \\
\text { Improdutivas }\end{array}$ & $\begin{array}{l}\text { Bulbinhos } \\
\text { Precoces }\end{array}$ \\
\hline Amarela Chata das Canärtas & $2.42 a^{\star \star}$ & $46,0.0^{\star \star}$ & $266 \mathrm{ab}^{\star \star}$ & $225 e^{\star \star}$ & $39 \mathrm{de}^{\star \star}$ & $11 \cot \theta^{\star \star}$ \\
\hline Texas Early Grano & $1.95 \mathrm{abc}$ & $27.1 \mathrm{bcd}$ & 266 ab & $210 \mathrm{ab}$ & 228 & 30 ab \\
\hline Bala do Cedo & $1,86 \mathrm{bc}$ & $27.0 \mathrm{bcd}$ & $264 a b$ & 198 ab & $42 \cot \theta$ & $24 a b c$ \\
\hline Bato do Cedo A SMJ-III & $1,87 \mathrm{bc}$ & $30,7 \mathrm{bcd}$ & 2800 & 187 ba & $83 \mathrm{~b}$ & $09 \mathrm{de}$ \\
\hline Bala do Cedo B SMJ-III & $2,03 a b c$ & $33,3 \mathrm{bc}$ & 272 ab & 205 ab & $58 \mathrm{bcd}$ & $08 \mathrm{de}$ \\
\hline Compos to Bala & $1.57 \mathrm{~cd}$ & $21,9 \mathrm{~cd}$ & $240 \mathrm{~b}$ & $170 \mathrm{D}$ & $34 \mathrm{de}$ & 360 \\
\hline Compos to Baia SMJ-III & $2,10 \mathrm{ab}$ & $34,8 \mathrm{ab}$ & $287 a$ & $210 a b$ & $67 \mathrm{bc}$ & $11 \operatorname{cote}$ \\
\hline Bato Triunfo SMJ-I & $1.91 \mathrm{bc}$ & $31,2 \mathrm{bcd}$ & 262 & $193=b$ & 55 bed & $15 \mathrm{bod}$ \\
\hline Baia Triunfo SMJ-III & $1.15 d$ & 20,50 & 2840 & $191 \mathrm{c}$ & $170 \mathrm{a}$ & $03 \mathrm{e}$ \\
\hline
\end{tabular}

*: Dados obtidos numa parcela de $6.0 \mathrm{~m}^{2}$ com lotaçäo inicial de 300 plantas.

Experimento en blocos casualizados com 6 repetiçóes.

*: Médias dentro da coluna seguidas da mesma letra näo diferen significativamenta pelo testa de Tukey. ao nível de 5\% de probabilidade. 
Tabela 07 - Valores e significâncias dos quadrados médios para o carāter bulbos comerciais classificados em trés categorias de peso. Cultivo de verão. Experimento I. Belém do São Francisco, PE. , 1977/78.

\begin{tabular}{|c|c|c|c|c|}
\hline \multirow{2}{*}{ Fontes de Variação } & \multirow{2}{*}{ G.L. } & \multicolumn{3}{|c|}{ Quadrados Médios } \\
\hline & & $P_{1}$ & $P_{2}$ & $P_{3}$ \\
\hline Repetições & 5 & $7,24 * \star$ & $24,82 \star \star$ & $1,05 * \star$ \\
\hline Tratamentos (Populações) & 11 & $7,98 * \star$ & $15,43^{\star \star}$ & $0,51 * \star$ \\
\hline Entre Grupos & 4 & $1,99 \mathrm{~ns}$ & $5,92^{\star}$ & $1,07 \star \star$ \\
\hline Entre Grupos Baia & 3 & $2,64 \mathrm{~ns}$ & $5,39 *$ & $0,13 \mathrm{~ns}$ \\
\hline Test. vs. Grupos Baia & 1 & $0,05 \mathrm{~ns}$ & $7,48^{\star}$ & $3,90 \star \star$ \\
\hline Ciclos $\mathrm{BC}_{\mathrm{B}}$ & 1 & $14,26 \star \star$ & $18,80 * \star$ & $0,28 \mathrm{~ns}$ \\
\hline Ciclos $B C_{A}$ & 2 & $4,11 \star$ & $18,04 * \star$ & $0,06 \mathrm{~ns}$ \\
\hline Regressão linear/BC ${ }_{A}$ & 1 & $8,09 * \star$ & $35,98 * \star$ & $0,03 \mathrm{~ns}$ \\
\hline Regressão quadrática/BC ${ }_{A}$ & 1 & $0,13 \mathrm{~ns}$ & $0,10 \mathrm{~ns}$ & $0,08 \mathrm{~ns}$ \\
\hline Ciclos CB & 2 & $18,59 \star \star$ & $20,12 \star \star$ & $0,27 \mathrm{~ns}$ \\
\hline Regressão linear/CB & 1 & $31,75^{\star \star}$ & $27,91 * \star$ & $0,01 \mathrm{~ns}$ \\
\hline Regressão quadrática/CB & 1 & $5,43^{\star}$ & $12,34^{\star \star}$ & $0,54 \mathrm{~ns}$ \\
\hline Ciclos BT & 2 & $10,06 \star \star$ & $25,46^{\star \star}$ & $0,17 \mathrm{~ns}$ \\
\hline Regressão linear/BT & 1 & $19,66^{\star \star}$ & $49,00 \star \star$ & $0,34 \mathrm{~ns}$ \\
\hline Regressão quadrātica/BT & 1 & 0,47 ns & $1,92 \mathrm{~ns}$ & $0,00 \mathrm{~ns}$ \\
\hline Resíduo & 55 & 1,00 & 1,70 & 0,17 \\
\hline Médi a Geral & & 8,58 & 7,18 & 1,01 \\
\hline Coeficiente de Variação & & 11,65 & 18,10 & 44,55 \\
\hline Unidade & & $\begin{array}{c}\sqrt{X} \\
\text { x: nọ de } \\
\text { bulbos }\end{array}$ & Y: ${ }^{\sqrt{\gamma}}$ de & $\begin{array}{c}\sqrt{\mathrm{Z}+0,5} \\
Z: \text { nọ de } \\
\text { bulbos }\end{array}$ \\
\hline
\end{tabular}

ns: não significativo; *: significativo a $5 \%$ e $*$ : significativo a $1 \%$ de probabilidade; $P_{1}$ : bulbos comerciais < $50 \mathrm{~g} ; P_{2}$ : bulbos comerciais entre 50 e $150 \mathrm{~g} ; P_{3}$ : bulbos comerciais > $150 \mathrm{~g}$. Grupos: Testemunha (Canárias); Baia do Cedo B (SMJ-I e SMJ-II); Baia do Cedo A (SMJ-I, SMJ-II e SMJ-III); Composto Baia (SMJ-I, SMJ-II e SMJ-III) e Baia Triunfo (SMJ-0, SMJ-I e SMJ-II) 
Tabela 08 - Valores e significāncias dos quadrados médios para o carāter bulbos comerciais classificados em très categorias de peso. Cultivo de fevereiro-julho. Experimento II. Belēm do São Francisco, PE., 1978.

\begin{tabular}{|c|c|c|c|c|}
\hline \multirow{2}{*}{ Fontes de Variação } & \multirow{2}{*}{ G.L. } & \multicolumn{3}{|c|}{ Quadrados Médios } \\
\hline & & $P_{1}$ & $P_{2}$ & $P_{3}$ \\
\hline & & & & $>$ \\
\hline Repetições & 5 & $4,32 \star \star$ & $5,76 \star \star$ & $6,69 \star \star$ \\
\hline Tratamentos (Populações) & 11 & $6,32 \star \star$ & $4,02 * \star$ & $2,27 \mathrm{~ns}$ \\
\hline Entre Grupos & 4 & $8,01 * \star$ & $6,03 \star \star$ & $4,10 \mathrm{~ns}$ \\
\hline Entre Grupos Baia & 3 & $6,24 \star \star$ & $5,76^{\star}$ & $2,73 \mathrm{~ns}$ \\
\hline Test. vs. Grupos Baia & 1 & $13,33^{\star \star}$ & $6,84^{*}$ & $0,02 \mathrm{~ns}$ \\
\hline Ciclos $\mathrm{BC}_{\mathrm{B}}$ & 1 & $0,00 \mathrm{~ns}$ & $0,15 \mathrm{~ns}$ & $0,22 \mathrm{~ns}$ \\
\hline Ciclos $\mathrm{BC}_{\mathrm{A}}$ & 2 & $0,60 \mathrm{~ns}$ & $4,84 * \star$ & $2,14 \mathrm{~ns}$ \\
\hline Regressão linear/BC ${ }_{A}$ & 1 & $0,99 \mathrm{~ns}$ & $5,41 \mathrm{~ns}$ & $4,26 \mathrm{~ns}$ \\
\hline Regressão quadrática/BC ${ }_{A}$ & 1 & $0 ; 20 \mathrm{~ns}$ & $4,27 \mathrm{~ns}$ & $0,03 \mathrm{~ns}$ \\
\hline Ciclos CB & 2 & $1,91 *$ & 1,32 ns & $2,88 \mathrm{~ns}$ \\
\hline Regressão linear/CB & 1 & $3,67 * \star$ & $0,26 \mathrm{~ns}$ & $0,95 \mathrm{~ns}$ \\
\hline Regressão quadrática/CB & 1 & $0,13 \mathrm{~ns}$ & $2,38 \mathrm{~ns}$ & $2,81 \mathrm{~ns}$ \\
\hline Ciclos BT & 2 & $16,23^{\star \star}$ & $3,81 \mathrm{~ns}$ & $3,24 \mathrm{~ns}$ \\
\hline Regressão linear/BT & 1 & $31,92 * \star$ & $6,74^{\star}$ & $6,47 \mathrm{~ns}$ \\
\hline Regressão quadrática/BT & 1 & $0,54 \mathrm{~ns}$ & $0,88 \mathrm{~ns}$ & $0,01 \mathrm{~ns}$ \\
\hline Resíduo & 55 & 0,51 & 1,47 & 1,67 \\
\hline Média Geral & & 5,79 & 11,43 & 3,53 \\
\hline Coeficiente de Variação & & 12,26 & 10,59 & 36,54 \\
\hline Unidade & & $\begin{array}{r}x: \text { no } \\
\text { bulbos }\end{array}$ & $\begin{array}{l}\bar{y} \quad Y: \text { no } \\
\text { e bulbos }\end{array}$ & $\begin{array}{r}\overline{Z+0,5} \mathrm{Z}: \\
\text { de bulbo }\end{array}$ \\
\hline
\end{tabular}

ns: não significativo: *: significativo a $5 \%$; $*$ : significativo a $1 \%$ de probabilidade; $P_{1}$ : bulbos comerciais < $50 \mathrm{~g} ; \mathrm{P}_{2}$ : bulbos comerciais entre 50 e $150 \mathrm{~g}$ e $\mathrm{P}_{3}$ : 1bulbos comerciais > $150 \mathrm{~g}$; ${ }^{1}$ Grupos: Testemuntia (Caná rias); Baia do'Cedo B (SMJ-I e SMJ-II); Baia do Cedo A (SMJ-I, SMJ-II è SMJ-III); Composto Baia (SMJ-I, SMJ-II e SMJ-III) e Baia Triunfo (SMJ-0, SMJ-I e SMJ-II). 
Tabela 09 - Valores e significâncias dos quadrados médios para o carāter bulbos comerciais classificados em três categorias de peso. Cultivo de inverno. Experimento III. Belēm do São Francis CO, PE., 1979.

\begin{tabular}{|c|c|c|c|c|}
\hline \multirow{2}{*}{ Fontes de Variação } & \multirow{2}{*}{ G.L. } & \multicolumn{3}{|c|}{ Q̨uadrados Médios } \\
\hline & & $P_{1}$ & $P_{2}$ & $P_{3}$ \\
\hline Repetiçōes & 05 & $1,52^{\star}$ & $7,30 * \star$ & $7,02^{*}$ \\
\hline Tratamentos & 08 & $10,26 * \star$ & $6,25 * \star$ & $8,66 *$ \\
\hline Resíduo & 40 & 0,53 & 1,25 & 0,81 \\
\hline Mēdia Geral & & 6,87 & 11,13 & 3,39 \\
\hline Coeficiente de Variação & & 10,62 & 10,06 & 26,55 \\
\hline Uni dade & & $\begin{array}{c}\sqrt{x} \\
x: \text { no de } \\
\text { bulbos }\end{array}$ & $\begin{array}{l}\sqrt{\gamma} \\
\text { Y: nọ de } \\
\text { butbos }\end{array}$ & $\begin{array}{l}\sqrt{Z} \\
\text { bujbó de }\end{array}$ \\
\hline
\end{tabular}

*: significativo a $5 \%$ e*: significativo a $1 \%$ de probabilidade pelo teste $F$.

$P_{1}$ : bulbos comerciais < $50 \cdot \mathrm{g}$

$P_{2}$ : bulbos comerciais entre 50 e $150 \mathrm{~g}$

$P_{3}$ : bulbos comerciais > $150 \mathrm{~g}$ 
Tabela 10 - Número médio de bulbos comerciais de cebola classificados em três categorias de peso.. Cultivo de verão. Experimento I. Belēm do São Francisco, PE., 1977/78.*

\begin{tabular}{|c|c|c|c|}
\hline Tratamentos & $P_{1}$ & $P_{2}$ & $P_{3}$ \\
\hline Amarela Chata das Canárias & $74 \mathrm{bc} * \star$ & $72 a b^{\star \star}$ & $03 a^{\star \star}$ \\
\hline Baia do Cedo B SMJ-I & $54 \mathrm{~cd}$ & 31 cde & $00 \mathrm{~b}$ \\
\hline Baia do Cedo B SMJ-II & 92 ab & 68 abc & 02 ab \\
\hline Baia do Cedo A SMJ-I & $61 \mathrm{bcd}$ & 38 bcde & $00 \mathrm{~b}$ \\
\hline Baia do Cedo A SMJ-II & 77 abc & 65 abcd & $01 \mathrm{ab}$ \\
\hline Baia do Cedo A SMJ-III & 89 ab & 88 a & $00 \mathrm{~b}$ \\
\hline Composto Baia SMJ-I & $39 \mathrm{~d}$ & 20 e & $00 \mathrm{~b}$ \\
\hline Composto Baia SMJ-II & 82 abc & 62 abcd & 02 ab \\
\hline Composto Baia SMJ-III & $90 \mathrm{ab}$ & 56 abcd & $00 \mathrm{~b}$ \\
\hline Baia Triunfo SMJ-0 & 60 bcd & $28 \mathrm{de}$ & $00 \mathrm{~b}$ \\
\hline Baia Triunfo SMJ-I & $88 a b$ & 65 abcd & $00 \mathrm{~b}$ \\
\hline Baia Triunfo SMJ-II & 108 a & 90 a & $01 \mathrm{~b}$ \\
\hline
\end{tabular}

\footnotetext{
*: Parcela de $6,0 \mathrm{~m}^{2}$ com um nümero inicial de 300 plantas.

**: Médias dentro da coluna seguidas pela mesma letra não diferem significativamente pelo teste de Tukey, ao nível de 5\% de pro babilidade.

$P_{1}$ : bulbos comerciais < $50 \mathrm{~g}$; $P_{2}$ : bulbos comerciais entre 50 e $150 \mathrm{~g} ; P_{3}:$ bulbos comerciais $>150 \mathrm{~g}$.
} 
Tabela 11 - Nümero médio de bulbos comerciais de cebola classificados em três categorias de peso. Cultivo de fevereiro-julho. Expe rimento II. Belēm do São Francisco, PE., 1978.*

\begin{tabular}{|c|c|c|c|c|}
\hline Tratamentos & $P_{1}$ & $P_{2}$ & $P_{3}$ & \\
\hline Amarela Chata das Canārias & $56 a^{\star \star}$ & $156 a^{\star \star}$ & 14 & $a^{\star \star}$ \\
\hline Baia do Cedo B SMJ-I & $33 \mathrm{bc}$ & 131 ab & 12 & $a$ \\
\hline Baia do Cedo B SMJ-II & $33 \mathrm{bc}$ & 127 ab & 16 & a \\
\hline Baia do Cedo A SMJ-I & 39 abc & 171 a & 19 & a \\
\hline Baia do Cedo A SMJ-II & $33 \mathrm{bc}$ & $130 \mathrm{ab}$ & 14 & a \\
\hline Baia do Cedo A SMJ-III & $32 \mathrm{bc}$ & 138 ab & 12 & a \\
\hline Composto Baia SMJ-I & $46 \mathrm{ab}$ & 140 ab & 08 & a \\
\hline Composto Baia SMJ-II & $38 \mathrm{bc}$ & $121 \mathrm{ab}$ & 06 & a \\
\hline Composto Baia SMJ-III & $32 \mathrm{bc}$ & $134 a b$ & 16 & $a$ \\
\hline Baia Triunfo SMJ-0 & $46 a b$ & 127 ab & 11 & a \\
\hline Baia Triunfo SMJ-I & $23 \mathrm{~cd}$ & $122 \mathrm{ab}$ & 17 & a \\
\hline Baia Triunfo SMJ-II & $12 d$ & $95 \mathrm{~b}$ & 24 & $a$ \\
\hline
\end{tabular}

*: Parcela de $6,0 \mathrm{~m}^{2}$ com um número inicial de 300 plantas

**: Médias dentro da coluna seguidas pela mesma letra não diferem significativamente pelo teste de Tukey, ao nível de 5\% de pro babilidade.

$P_{1}$ : bulbos comerciais < $50 \mathrm{~g} ; P_{2}$ : bulbos comerciais entre 50 e $150 \mathrm{~g} ; \mathrm{P}_{3}$ : bulbos comerciais >150 $\mathrm{g}$. 
Tabela 12 - Nūmero médio de bulbos comerciais de cebola classificados em três categorias de peso. Cultivo de inverno. Experimento III. Belēm do São Francisco, PE., 1979.*

\begin{tabular}{lccc}
\hline \multicolumn{1}{c}{ Tratamentos } & $\mathrm{P}_{1}$ & $\mathrm{P}_{2}$ & $\mathrm{P}_{3}$ \\
\hline Amarela Chata das Canárias & $40 \mathrm{~d}^{\star \star}$ & $142 \mathrm{ab}^{\star \star}$ & $43 \mathrm{a}^{\star \star}$ \\
Texas Early Grano & $73 \mathrm{a}$ & 128 abc & $10 \mathrm{~b}$ \\
Baia do Cedo & 60 abc & 130 ab & $09 \mathrm{~b}$ \\
Baia do Cedo A SMJ-III & 46 bcd & 134 ab & $08 \mathrm{~b}$ \\
Baia do Cedo B SMJ-III & $42 \mathrm{~cd}$ & $149 \mathrm{a}$ & $14 \mathrm{~b}$ \\
Composto Baia & 64 ab & $98 \mathrm{bc}$ & $07 \mathrm{~b}$ \\
Composto Baia SMJ-III & 50 bcd & $148 \mathrm{a}$ & $12 \mathrm{~b}$ \\
Baia Triunfo SMJ-I & 54 abcd & 126 abc & $14 \mathrm{~b}$ \\
Baia Triunfo SMJ-III & 16 e & $84 \mathrm{c}$ & $10 \mathrm{~b}$ \\
\hline
\end{tabular}

*: Parcela de $6,0 \mathrm{~m}^{2}$ com um número inicial de 300 plantas.

**: Médias dentro da coluna seguidas da mesma letra não diferem significativamente pelo Teste de Tukey, ao nível de 5\% de probabilidade.

$P_{1}$ : bulbos comerciais < $50 \mathrm{~g}$

$P_{2}$ : bulbos comerciais entre 50 e $150 \mathrm{~g}$

$P_{3}$ : bulbos comerciais > $150 \mathrm{~g}$ 


\subsection{Figuras}



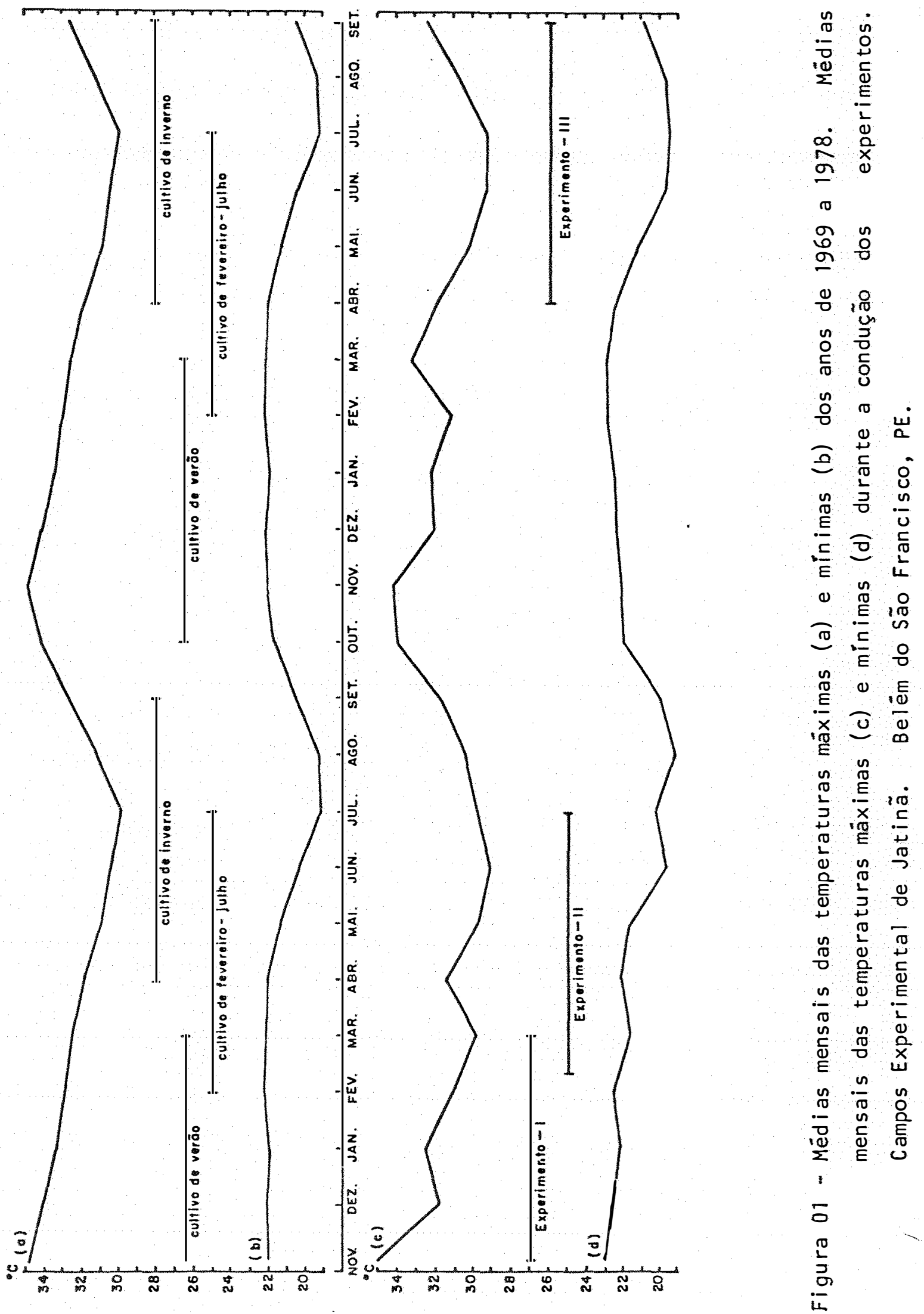


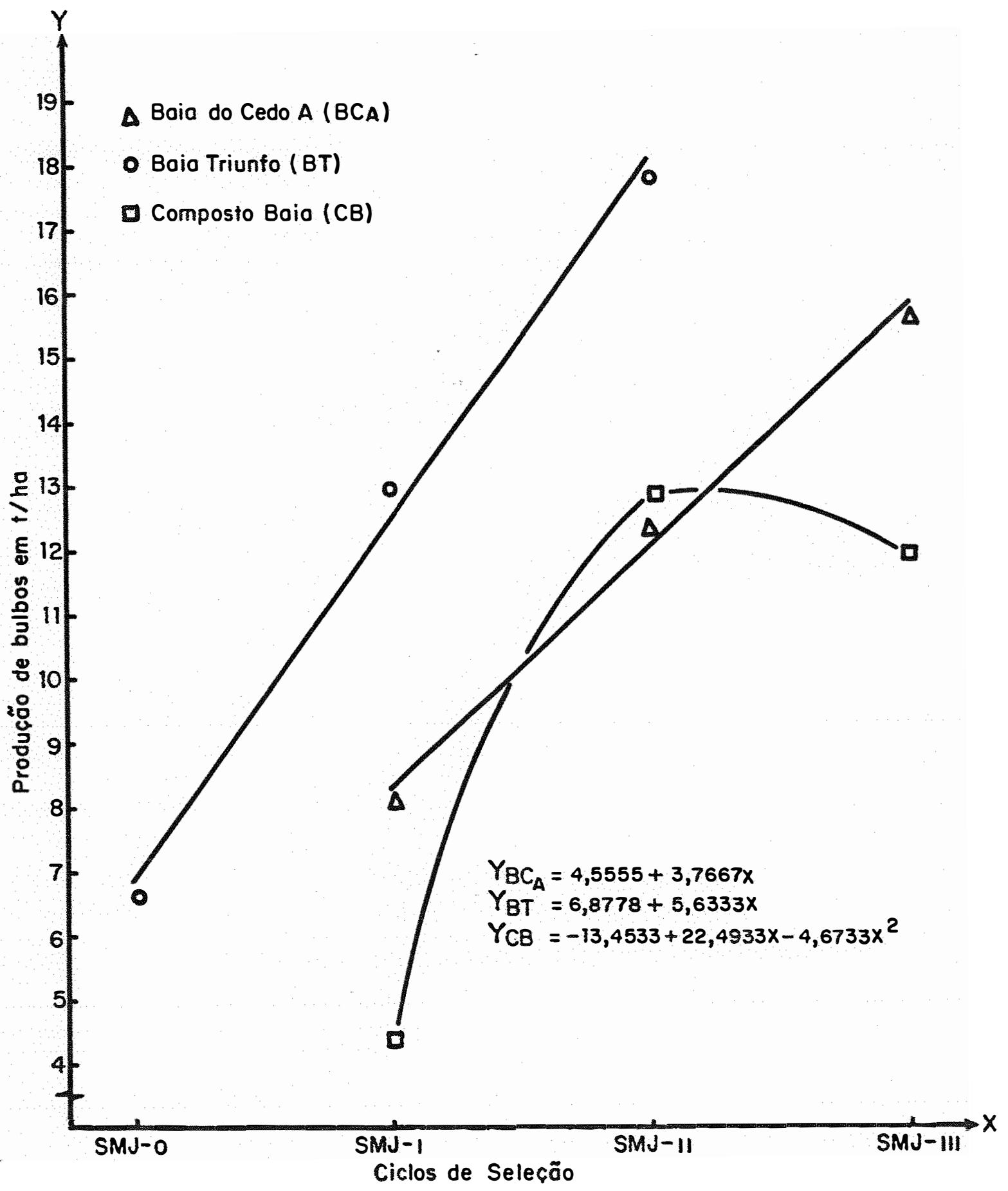

Figura 02 - Efeito da seleção massal estratificada (X) na produção (Y). Cultivo de verão. Experimento 1. Belēm do São Francisco, PE., $1977 / 78$. 


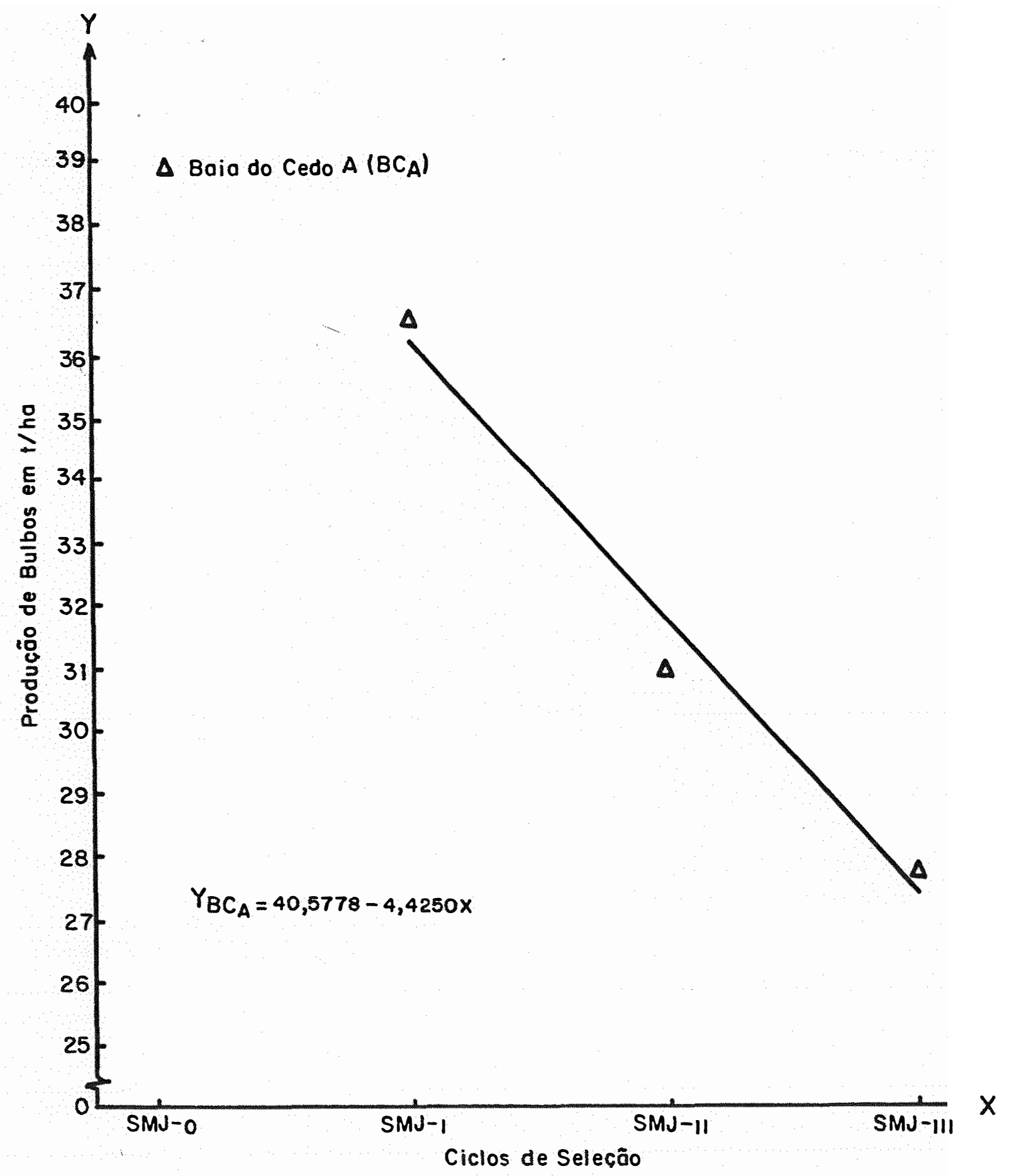

Figura 03 - Efeito da seleção massal estratificada (X) na produção (Y). Cultivo de fevereiro-julho. Experimento 11 . Belém do São Francisco, PE., 1978. 


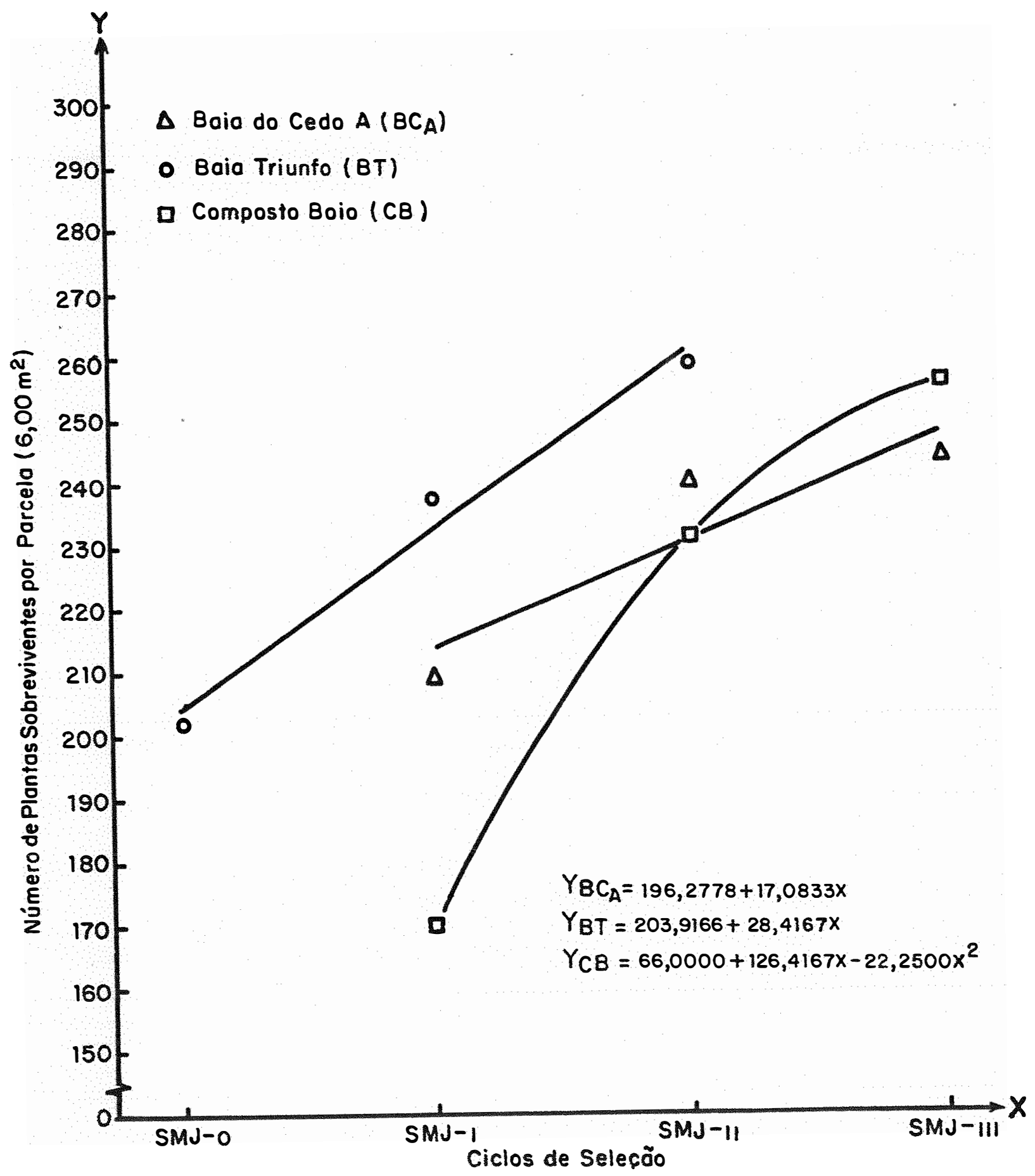

Vigura 04 - Efeito da seleção massal estratificada (X) na sobrevivência pós transplante $(Y)$. Cultivo de verão. Experimento 1. Belém do São Francisco, PE., $1977 / 78$. 


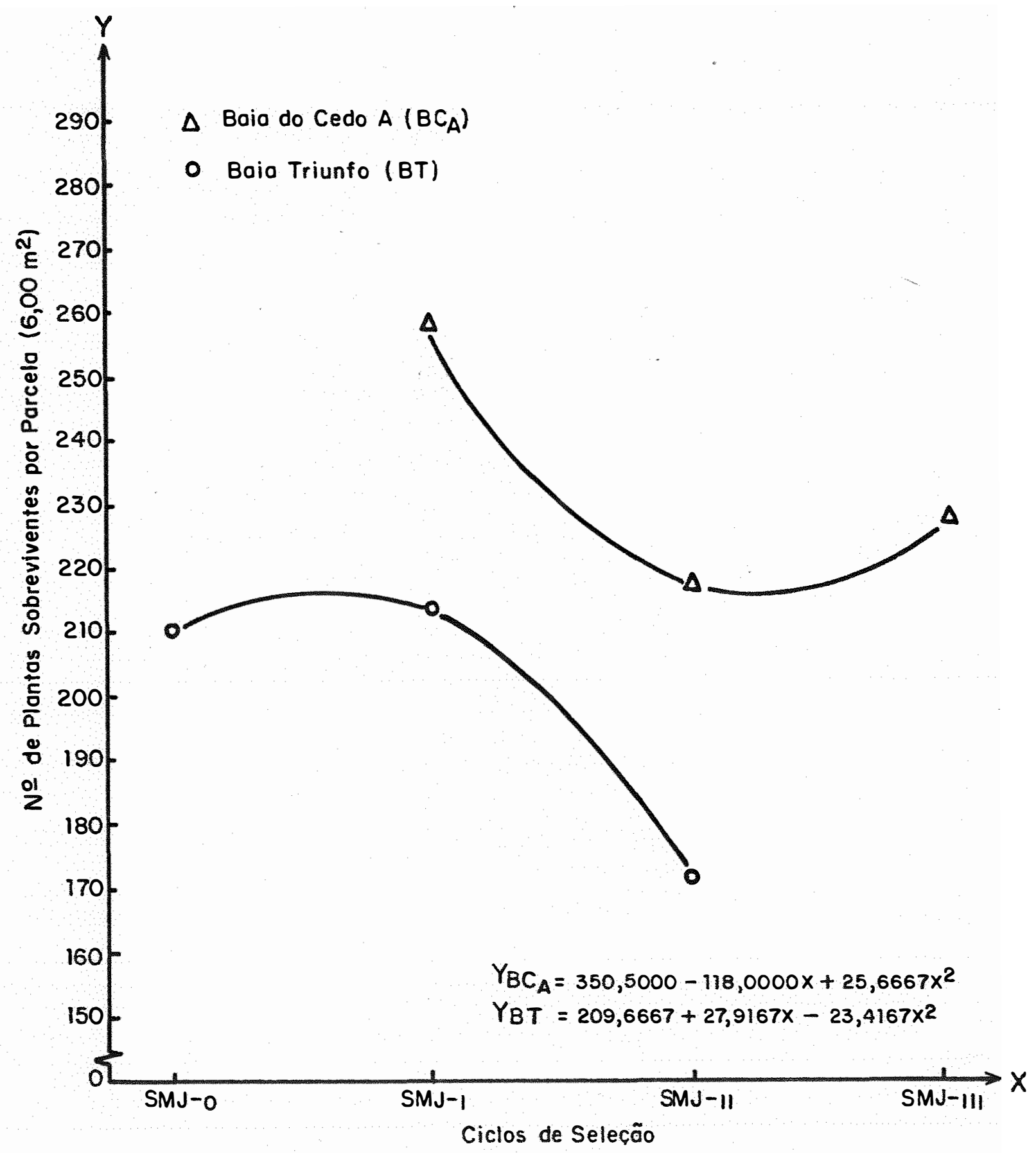

Figura 05 - Efeito da seleção massal estratificada (X) na sobrevivência pós transplante $(Y)$. Cultivo de fevereiro-julho. Experimento 11 . Belēm do São Francisco, PE., 1978. 


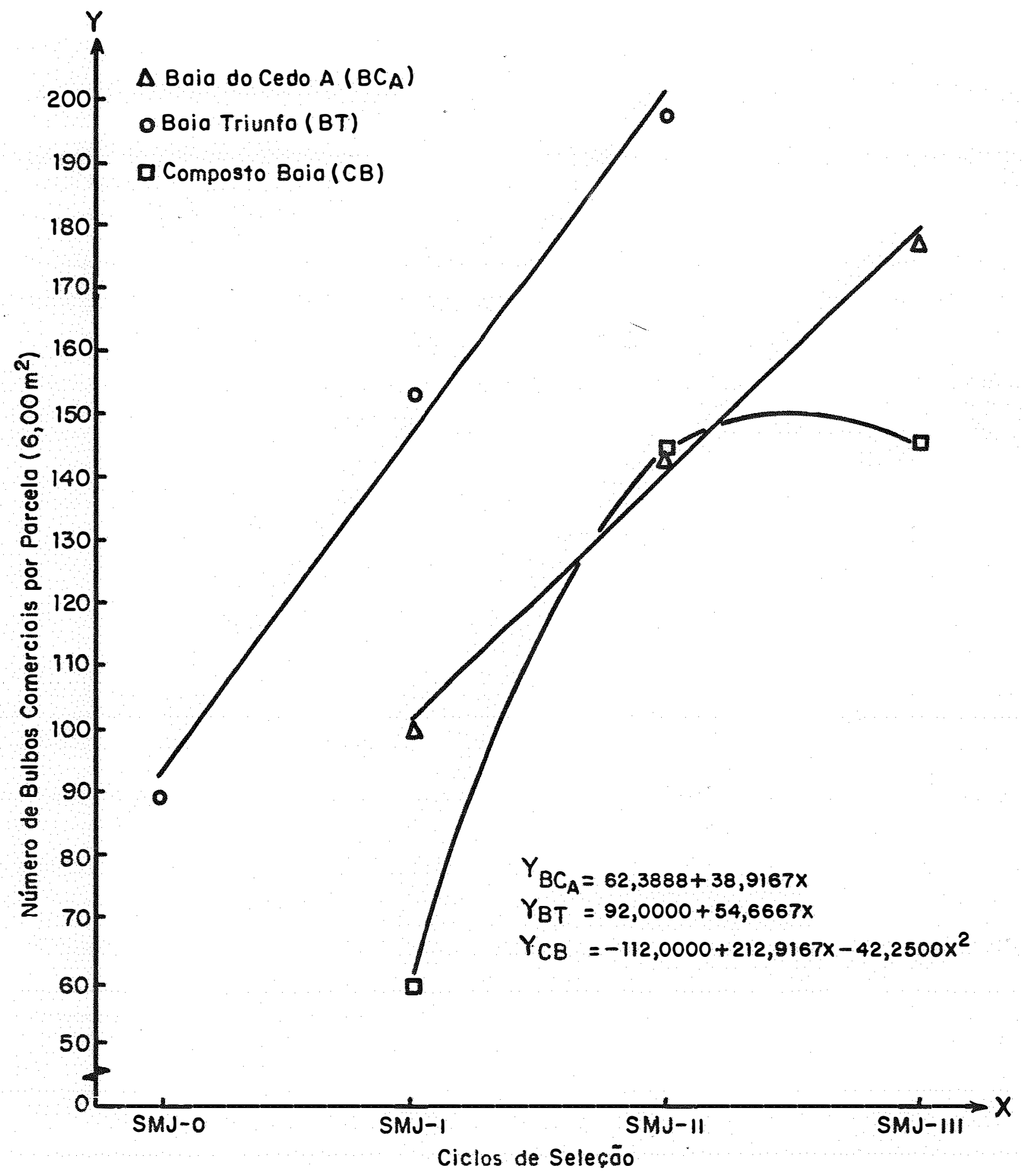

Figura 06 - Efeito da seleção massal estratificada (X) sobre o nümero de bul bos comerciais $(Y)$. Cultivo de verão. Experimento I. Belém do São Francisco, PE., $1977 / 78$. 


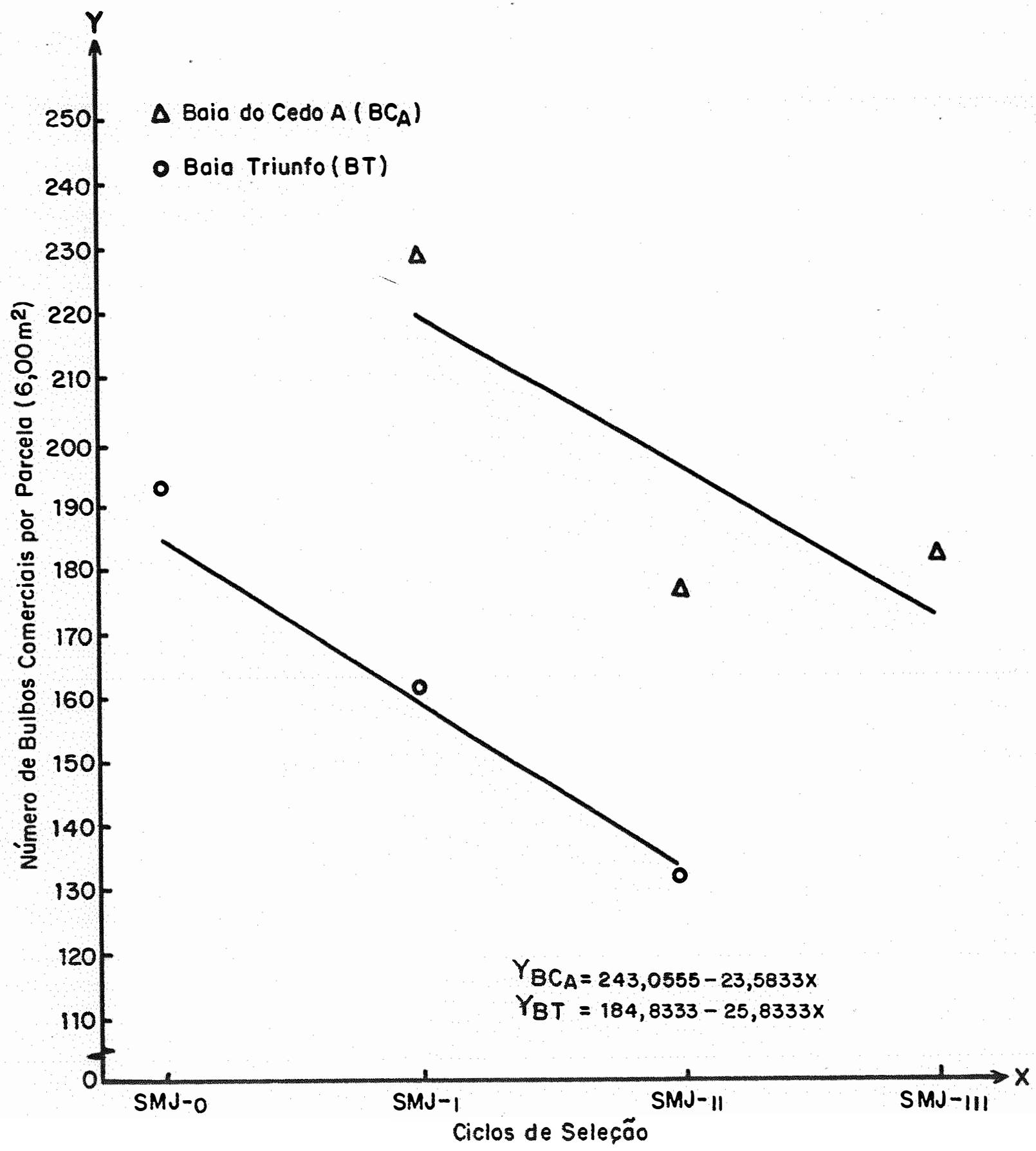

Figura 07 - Efeito da seleção massal estratificada (X) sobre o nümero de bul bos comerciais $(Y)$. Cultivo de fevereiro-julho. Experimento 11. Belém do São Francisco, PE., 1978. 


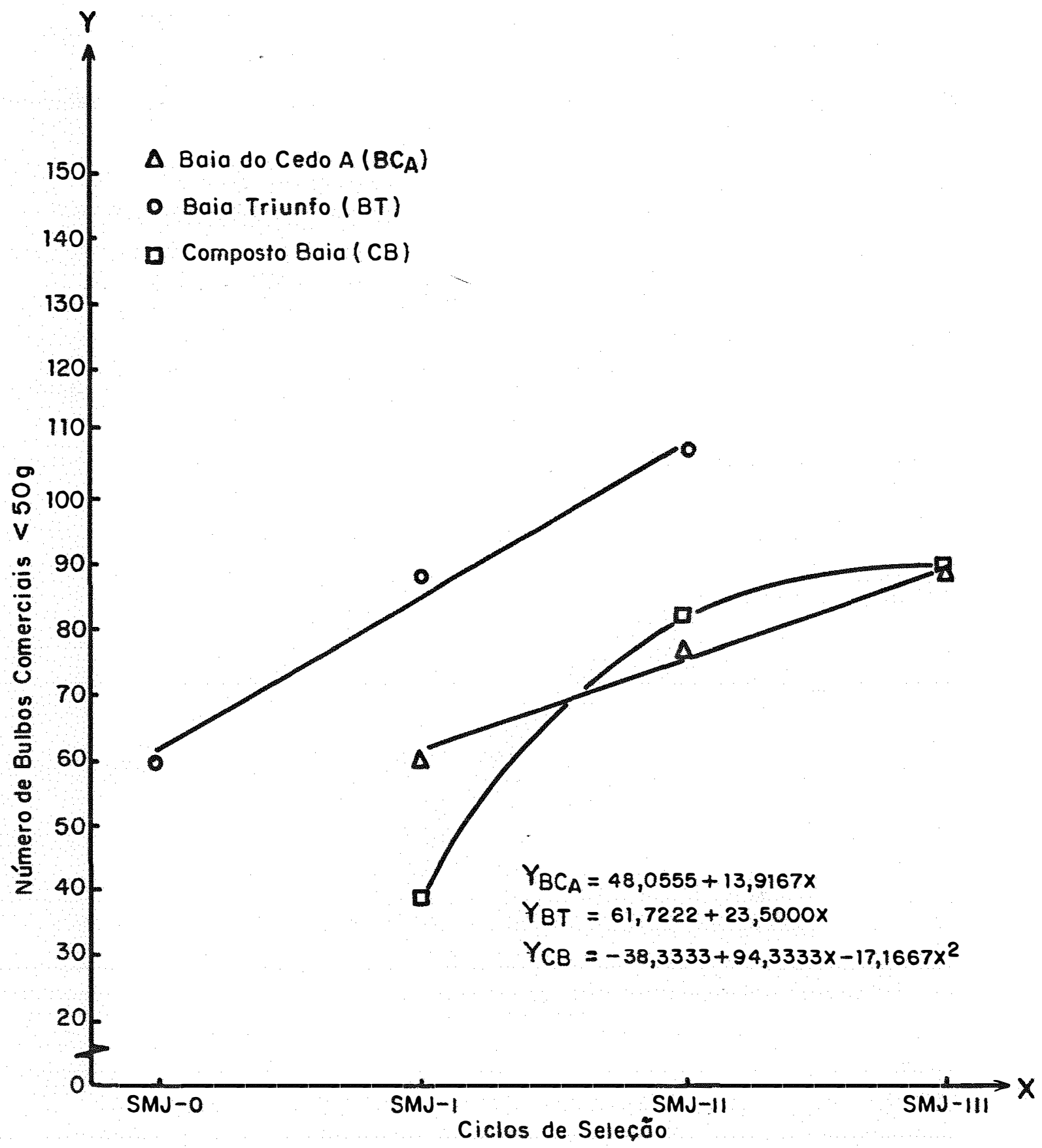

Figura 08 - Efeito da seleção massal estratificada (X) sobre o nümero de bul bos de peso inferior a $50 \mathrm{~g}(\mathrm{Y})$. Cultivo de verão. Experimento 1. Belèm do São Francisco, PE., $1977 / 78$. 


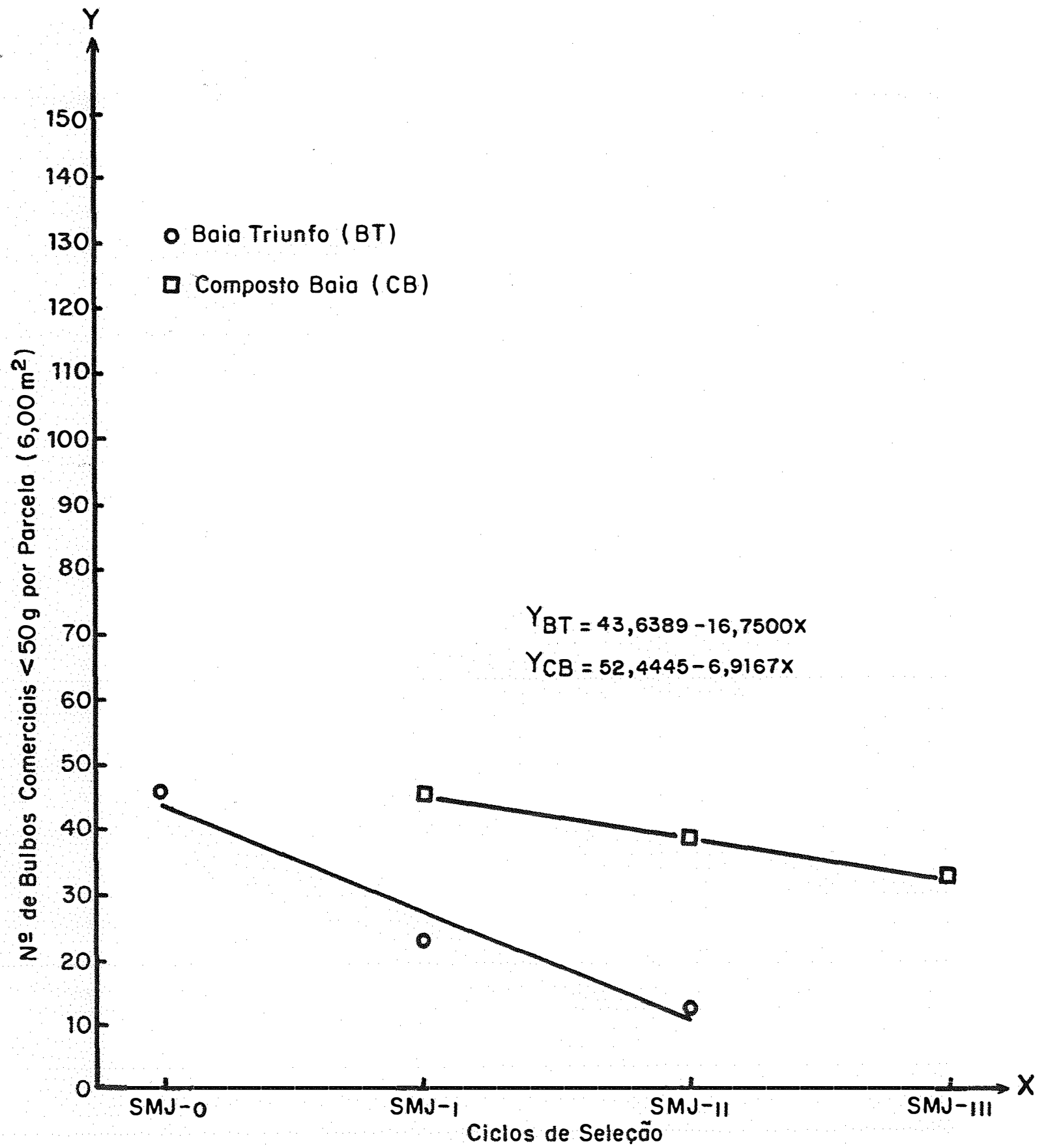

Figura 09 - Efeito da seleção massal estratificada (X) sobre o nümero de bul bos de peso inferior a $50 \mathrm{~g}(\mathrm{Y})$. Cultivo de fevereiro-julho. Experimento 11 . Belëm do São Francisco, PE,, 1978. 


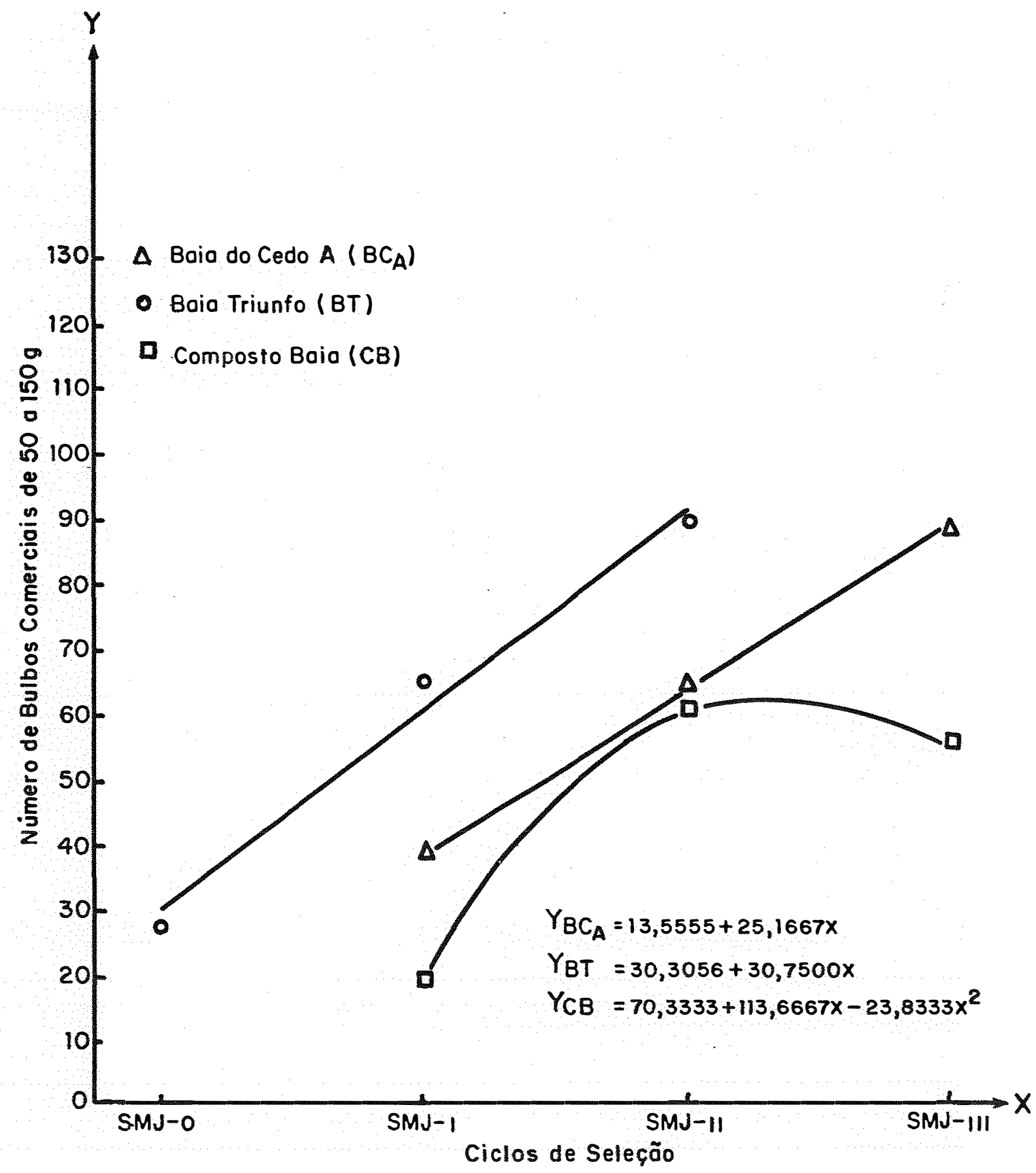

Figura 10 - Efeito da seleção massal estratificada (X) sobre o nümero de bul bos com peso entre 50 e $150 \mathrm{~g}(\mathrm{Y})$. Cultivo de verão. Experimento 1. Belēm do São Francisco, PE., $1977 / 78$. 


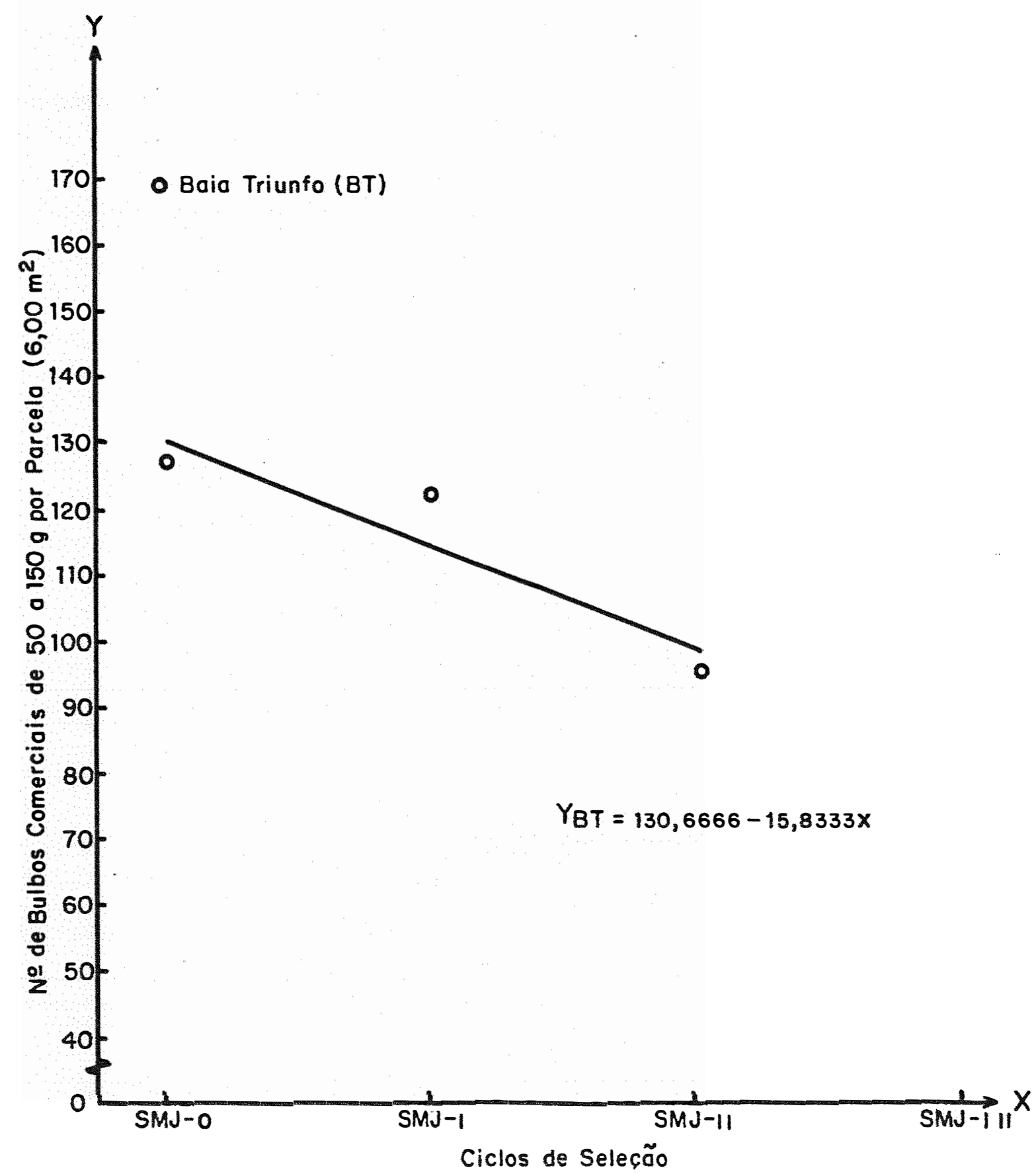

Figura 11 - Efeito da seleção massal estratificada (X) sobre o nümero de bul bos com peso entre 50 e $150 \mathrm{~g}(\mathrm{Y})$. Cultivo de fevereiro-julho. Experimento 11. Belēm do São Francisco, PE., 1978. 


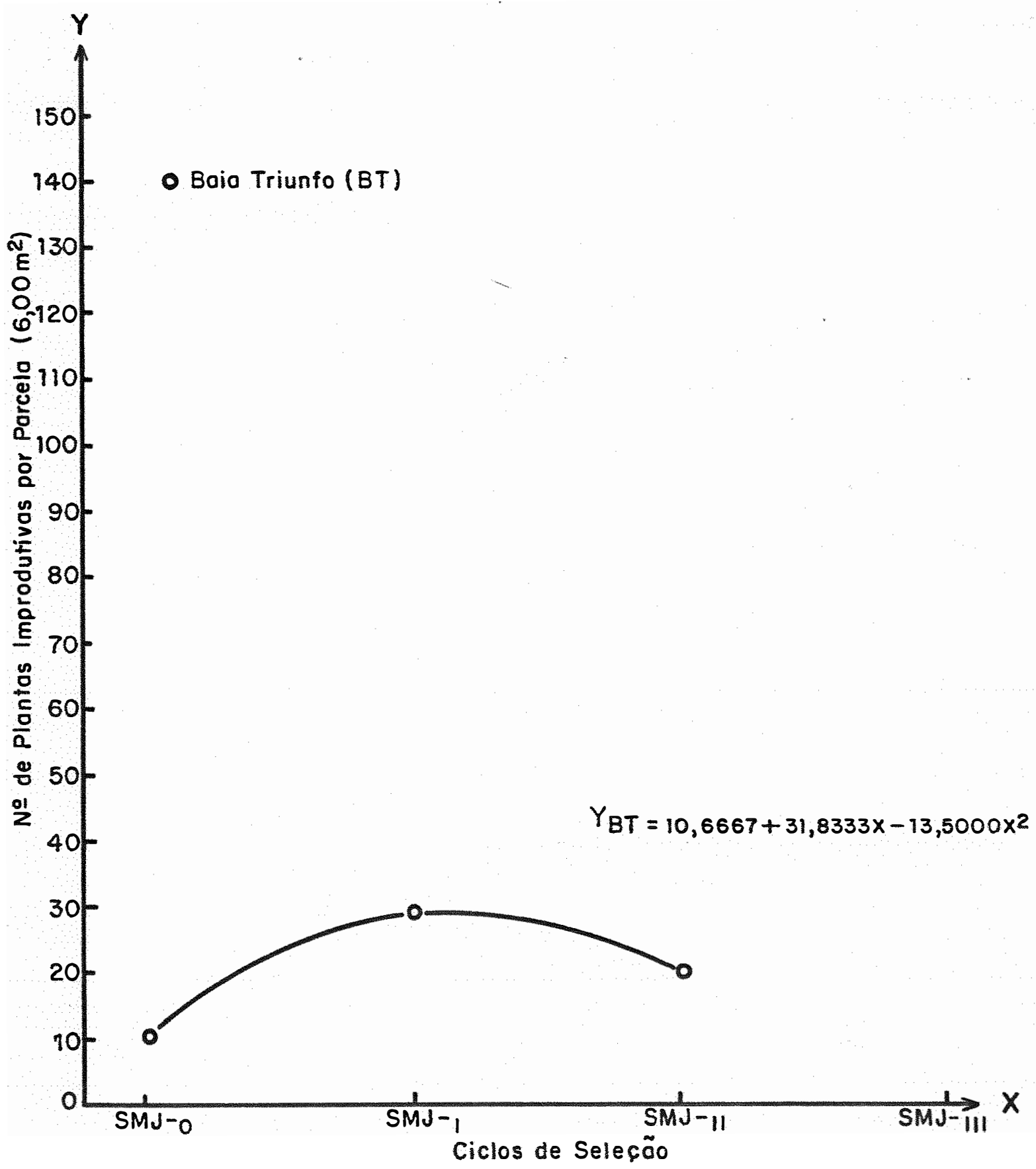

Figura 12 - Efeito da seleção massal estratificada (X) sobre o nümero de plantas improdutivas $(Y)$. Cultivo de verão. Experimento 1 . Belëm do São Francisco, PE., $1977 / 78$. 


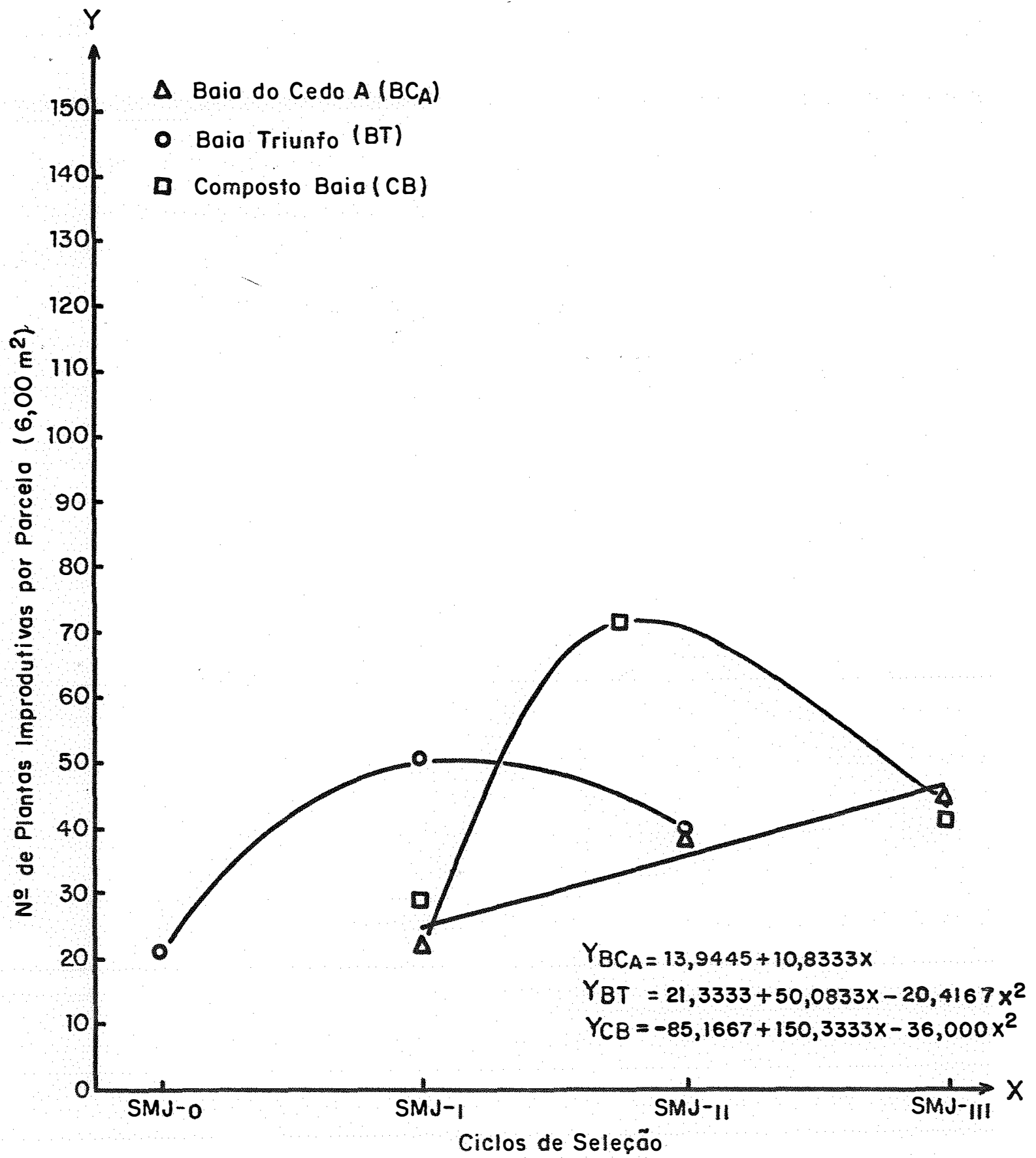

Figura 13 - Efeito da seleção massal estratificada (X) sobre o número de plantas improdutivas ( $y$ ). Cultivo de fevereiro-julho. Experimento 11. Belém do São Francisco, PE., 1978. 


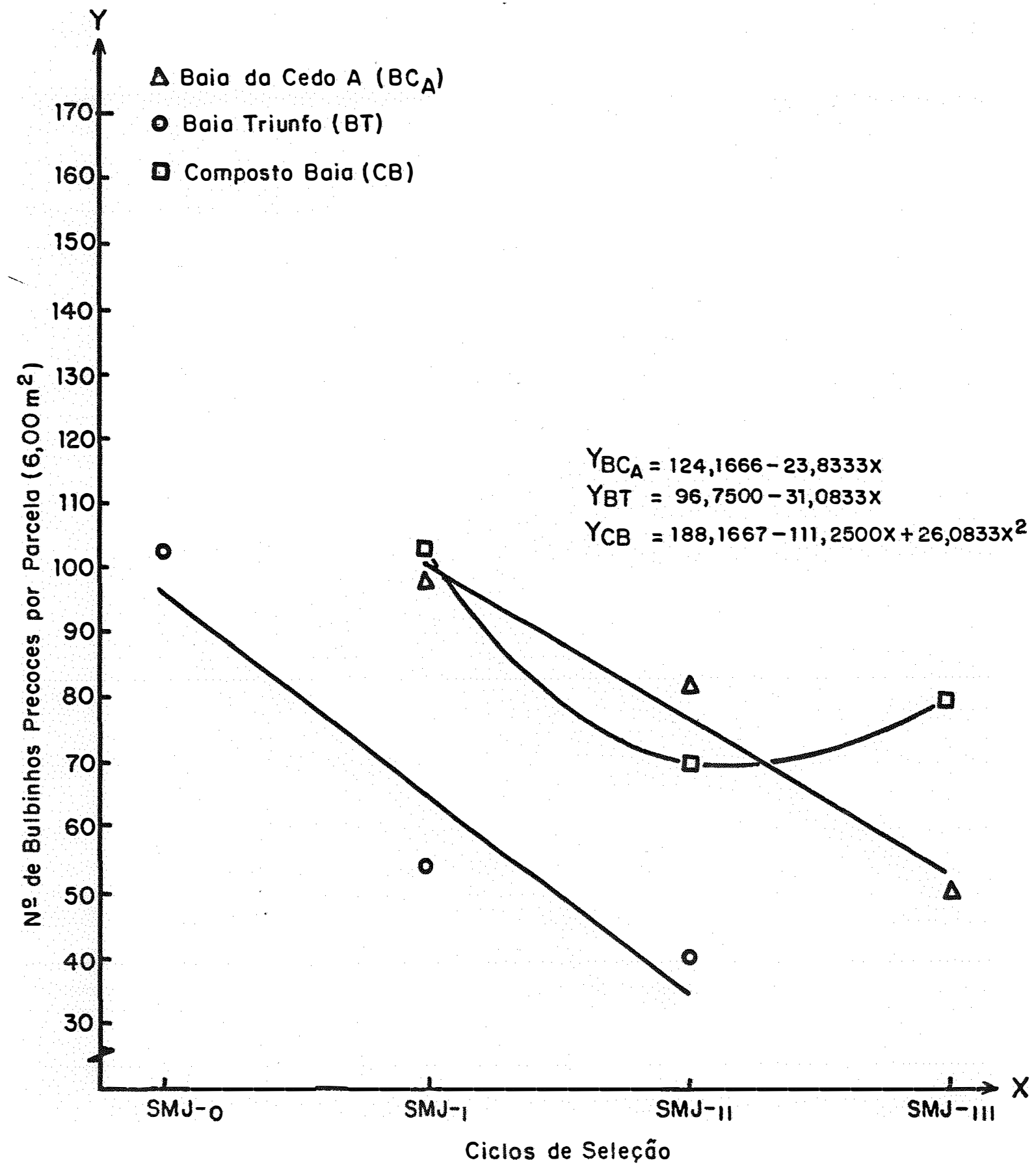

Figura 14 - Efeito da seleção massal estratificada $(X)$ sobre o nümero de bulbinhos precoces $(Y)$. Cultivo de verão. Experimento 1. Be lēm do São Francisco, PE., $1977 / 78$. 


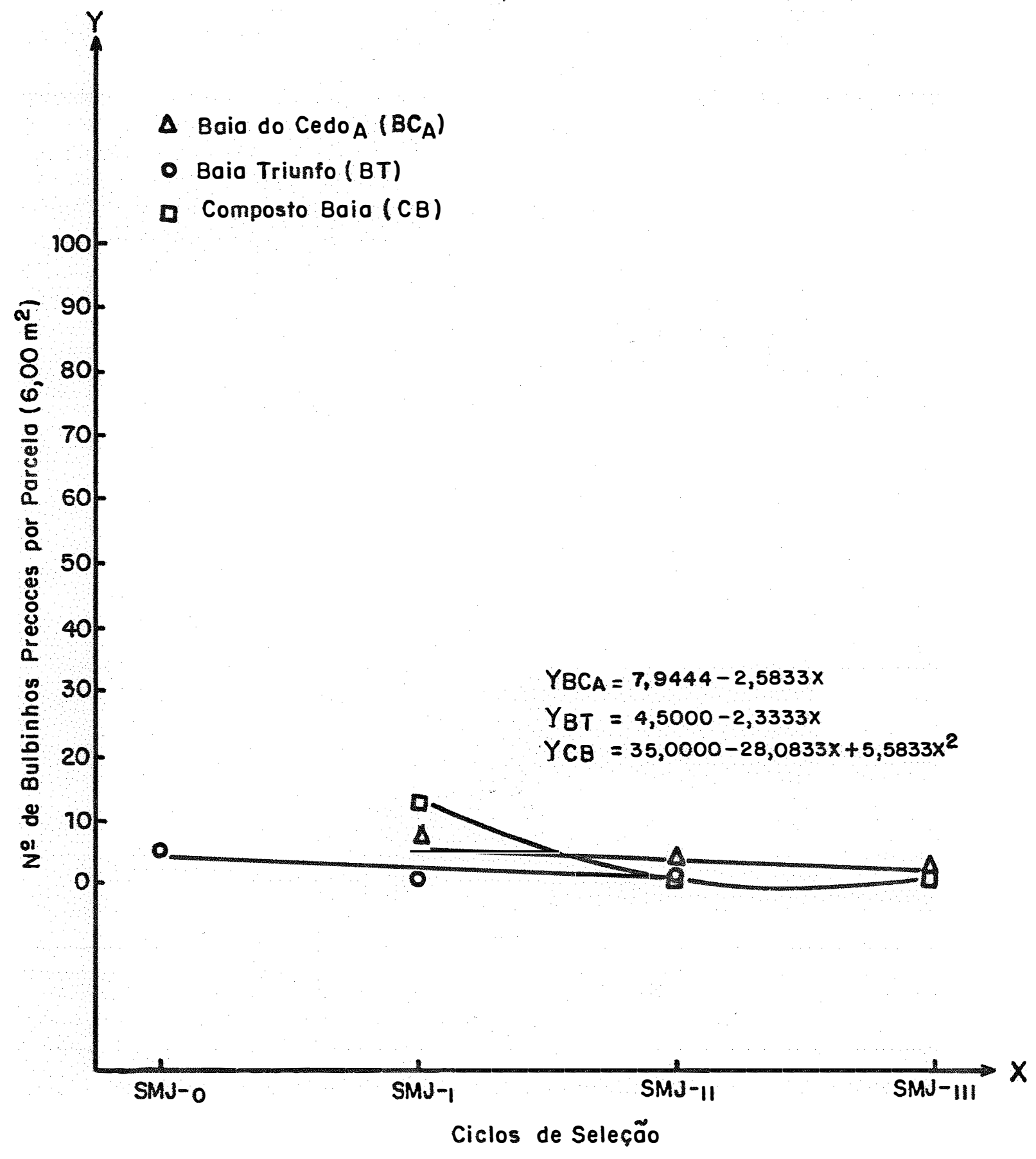

Figura 15 - Efeito da seleção massal estratificada (X) sobre o nūmero de bul binhos precoces $(Y)$. Cultivo de fevereiro-julho. Experimento 11. Belém do São Francisco, PE., 1978. 


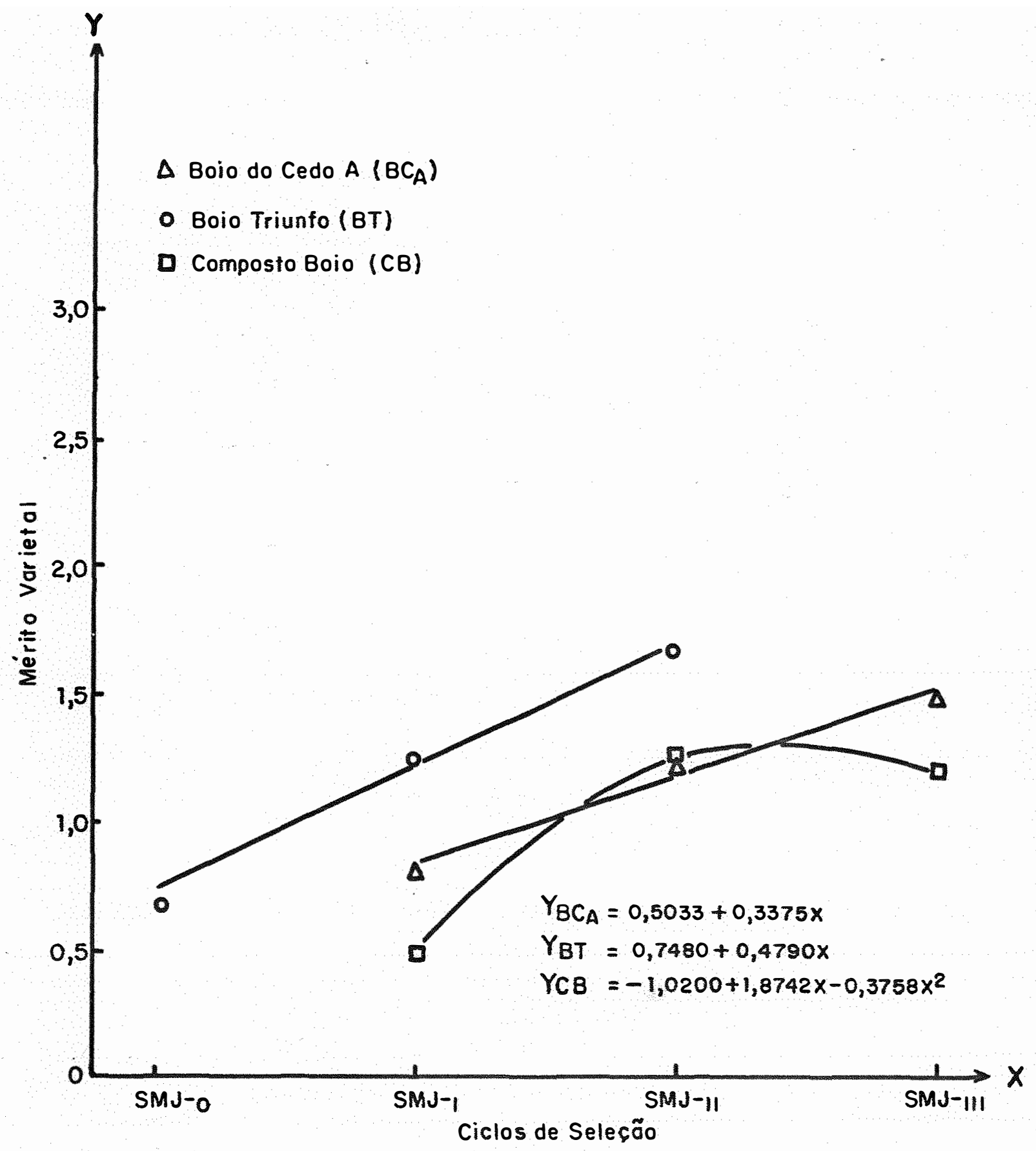

Figura 16 - Efeito da seleção massal estratificada (X) sobre o mérito varie tal (Y). Cultivo de verão. Experimento 1 . Belēm do São Francisco, PE., $1977 / 78$. 


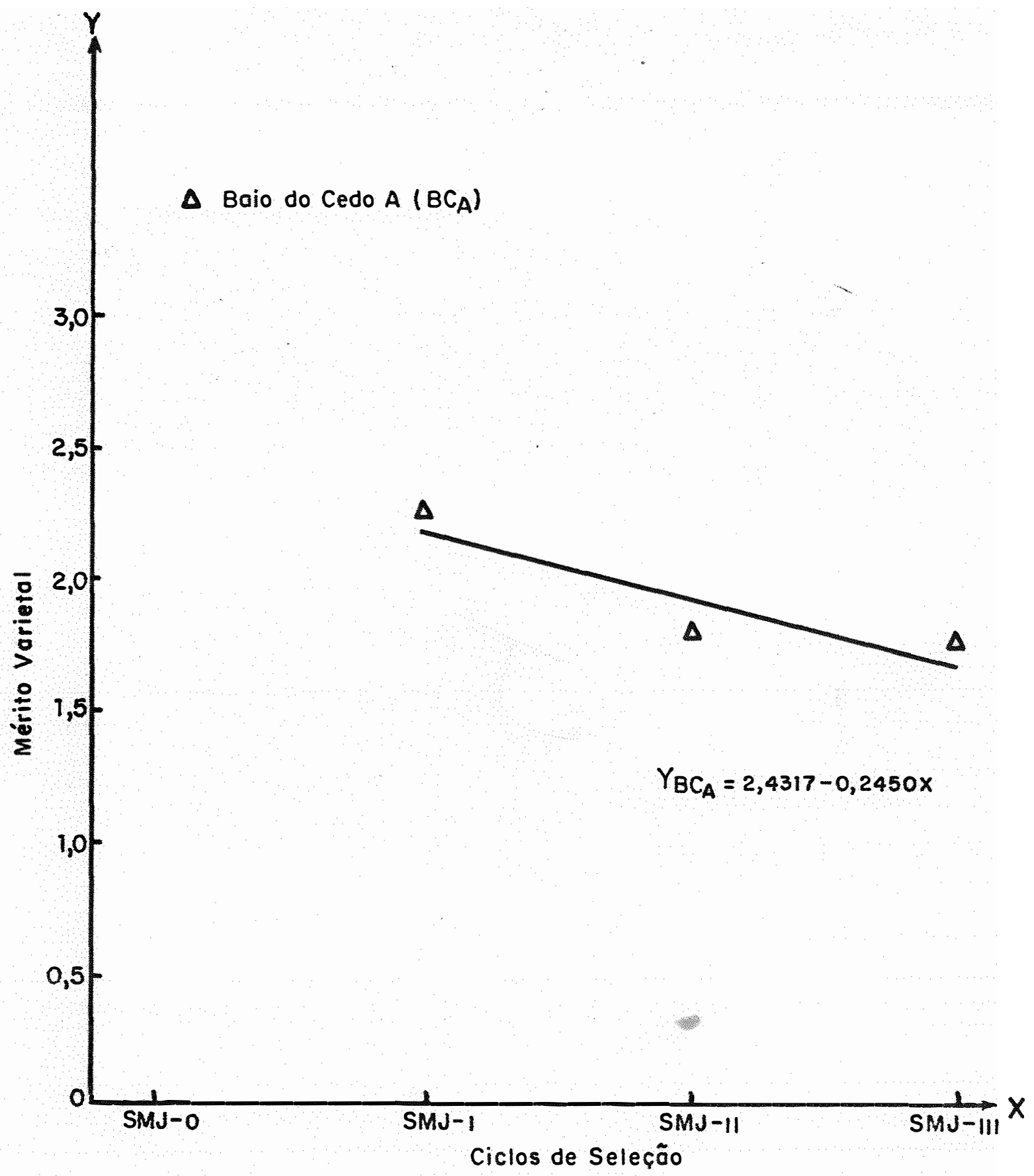

Figura 17 - Efeito da seleção massal estratificada $(X)$ sobre o mérito varietal $(Y)$. Cultivo de fevereiro-julho. Experimento 11 . Be lèm do São Francisco, PE., 1978. 